San Jose State University

SJSU ScholarWorks

Master's Theses

Master's Theses and Graduate Research

1990

Somatostatin and growth hormone releasing factor differentially regulate the release of immunoassayable and bioassayable growth hormone secretion from two populations of rat pituitary somatotrophs

Glenn H. Tietjen

San Jose State University

Follow this and additional works at: https://scholarworks.sjsu.edu/etd_theses

Recommended Citation

Tietjen, Glenn H., "Somatostatin and growth hormone releasing factor differentially regulate the release of immunoassayable and bioassayable growth hormone secretion from two populations of rat pituitary somatotrophs" (1990). Master's Theses. 78. DOI: https://doi.org/10.31979/etd.4rc9-8tjw https://scholarworks.sjsu.edu/etd_theses/78

This Thesis is brought to you for free and open access by the Master's Theses and Graduate Research at SJSU ScholarWorks. It has been accepted for inclusion in Master's Theses by an authorized administrator of SJSU ScholarWorks. For more information, please contact scholarworks@sjsu.edu. 


\section{INFORMATION TO USERS}

The most advanced technology has been used to photograph and reproduce this manuscript from the microfilm master. UMI films the text directly from the original or copy submitted. Thus, some thesis and dissertation copies are in typewriter face, while others may be from any type of computer printer.

The quality of this reproduction is dependent upon the quality of the copy submitted. Broken or indistinct print, colored or poor quality illustrations and photographs, print bleedthrough, substandard margins, and improper alignment can adversely affect reproduction.

In the unlikely event that the author did not send UMI a complete manuscript and there are missing pages, these will be noted. Also, if unauthorized copyright material had to be removed, a note will indicate the deletion.

Oversize materials (e.g., maps, drawings, charts) are reproduced by sectioning the original, beginning at the upper left-hand corner and continuing from left to right in equal sections with small overlaps. Each original is also photographed in one exposure and is included in reduced form at the back of the book.

Photographs included in the original manuscript have been reproduced xerographically in this copy. Higher quality 6" x 9" black and white photographic prints are available for any photographs or illustrations appearing in this copy for an additional charge. Contact UMI directly to order.

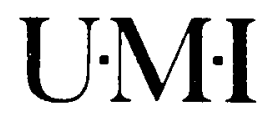

University Microfıms internalıonal

A Bell \& Howell Information Company

300 North Zeeb Road. Ann Arbor, MI 48106.1346 USA

313:761-4700 800:521-0600 

Order Number 1942740

Somatostatin and growth hormone releasing factor differentially regulate the release of immunoassayable and bioassayable growth hormone secretion from two populations of rat pituitary somatotrophs

Tietjen, Glenn Howard, M.S.

San Jose State University, 1990

$\mathrm{U} \cdot \mathrm{M} \cdot \mathrm{I}$

300 N. Zeeb Rd.

Ann Arbor, MI 48106 



\section{NOTE TO USERS}

THE ORIGINAL DOCUMENT RECEIVED BY U.M.I. CONTAINED PAGES WITH BLACK MARKS. PAGES WERE FILMED AS RECEIVED.

THIS REPRODUCTION IS THE BEST AVAILABLE COPY. 



\title{
SOMATOSTATIN AND GROWTH HORMONE RELEASING FACTOR DIFFERENTIALLY REGULATE THE RELEASE OF IMMUNOASSAYABLE AND BIOASSAYABLE GROWTH HORMONE SECRETION FROM TWO POPULATIONS OF RAT PITUITARY SOMATOTROPHS
}

\author{
A Thesis \\ Presented to \\ The Faculty of the Department of Biological Sciences \\ San Jose State University \\ In Partial Fulfillment \\ of the Requirements for the Degree \\ Master of Arts
}

By

Glenn H. Tietjen

December, 1990 
APPROVED FOR THE DEPARTMENT OF BIOLOGICAL SCIENCES

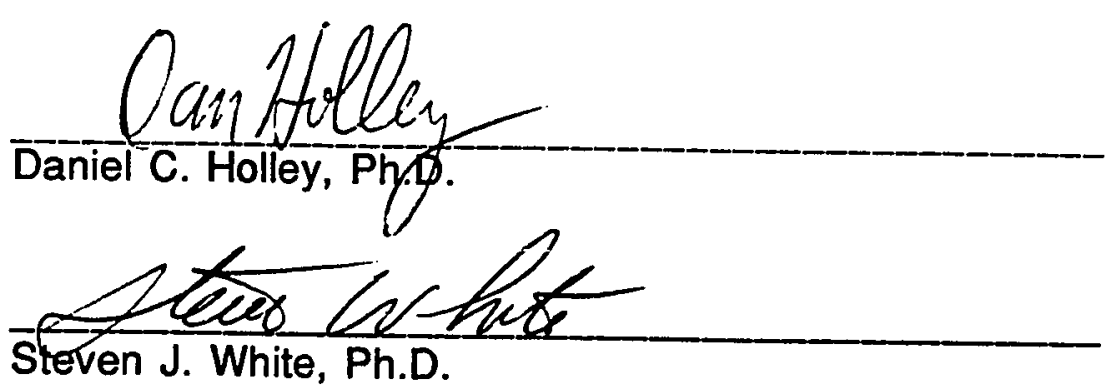

Steven J. White, PhD.

Repast Elimaluse

Richard E. Grindeland, PhD.

APPROVED FOR THE UNIVERSITY

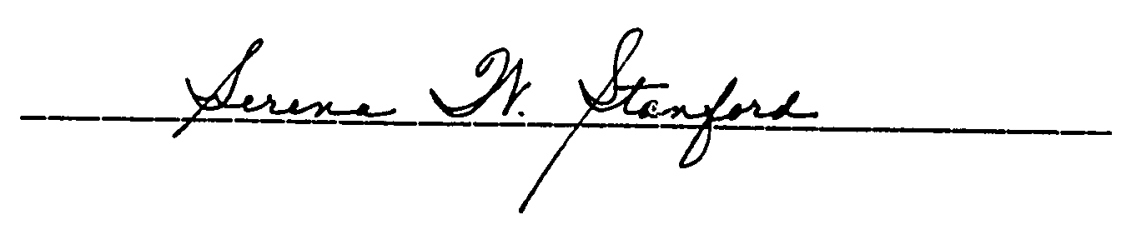

ii 


\section{Acknowledgements}

The research described herein is the result of the combined and varied efforts of many individuals. I would like to thank Dr. Paul Andriese for his early encouragement and support. He introduced me to Dr. Daniel C. Holley who served as my graduate advisor. Dr. Holley's efforts and encouragement introduced me to the research scientists in the Life Sciences Division of NASA-Ames Research Center, where all experiments were performed. Thanks to Dr. Steven J. White, San Jose State University, for spending the time to critique this thesis amidst his hectic schedule. Thanks to Dr. Sara B. Arnaud of NASA-Ames for allowing me to work in her Bone Hormone Lab for one and a half years prior to the project reported herein. Special thanks to Patricia Buckendahl, who personally taught me the techniques of radioimmunoassay, and offered emotional support when it was needed most. Special thanks to Dr. Richard E. Grindeland, NASA-Ames Research Center, for the extra effort he always made despite his numerous responsibilities and extremely busy schedule. His efforts, assistance, and support made this work possible. All experiments were performed in his labs. Special thanks to Marilyn Vasques and Juli Evans, NASA-Ames Research Center. Without their assistance during numerous experiments, often into the late hours of the night and the early morning, many of these experiments could not have been performed. Thanks to Dr. 
Wesley Hymer of Pennsylvania State University for serving as a consultant for many of the experiments described herein. Thanks to Kim Motter, also of Pennsylvania State University, for providing detailed information concerning culture procedures. Thanks to Dr. Jean Rivier of the Salk Institute for kindly providing the growth hormone releasing factors used in all experiments. Thanks to Dr. Tanjore Satyanarayana, whose critical discussions of experiments and procedures were invaluable. Thanks to Dr. Lanny Keil, Dr. Herb Ginoza, Dr. Liz Kraft and Dr. Jiro Oyama, all of NASA-Ames. Finally, thanks to my understanding wife, Lisa.

Funding for this project was provided by NASA grants \#NCA259 and 199-22-42-03. 


\section{Table of Conienis}

Acknowledgements.......................................................................................... i

List of Figures...........................................................................................

List of Tables................................................................................................... $\mathrm{i}$

Abstract .............................................................................................................

I. INTRODUCTION AND LITERATURE REVIEW...............................................1

A Note on Nomenclature ................................................................2

Measurement of Growth Hormone ......................................................

The Hypothalamic-Pituitary Axis In the Control of

Growth Hormone Release .........................................................................

Studies with Hypothalamic Extracts..............................................

Studies with Purified Growth Hormone Releasing Factor.........11

Somatostatin............................................................................................ 13

Growth Hormone Release During Stress, Hypoglycemia, and Spaceflight

Plasma Growth Hormone Concentrations and Unique Cell Culture Experiments.

Chemical Studies of Growth Hormone Variants .............................19

Neurotran'smitters and Regulation of Growth Hormone

Release.

Studies on Two Populations of Somatotrophs...............................25

Summary. 
Hypothesis

II. MATERIALS AND METHODS .......................................................................34

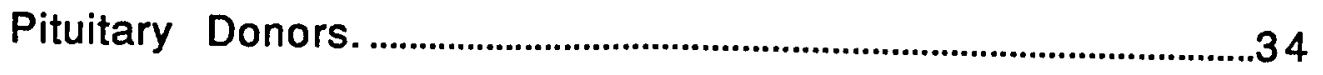

Preparation of Adenohypophyseal Cell Suspensions.....................34

Cell Counting, Dilutions, and Treatments.......................................36

Density Gradient Cell Separation Procedure...................................37

Cell Extracts for Intracellular Growth Hormone

Determination.

Viability Determination......................................................................40

Immunoperoxidase Staining of Somatotrophs................................40

Radioimmunoassay of Growth Hormone..........................................4 3

Bioassay of Growth Hormone ..............................................................44

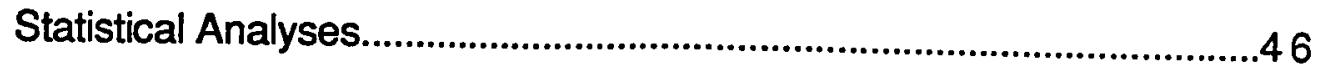

Experiment A: Mixed Cell Bioassayable and Immunoassayable Growth Hormone Secretion in Response to Human Pancreatic Growth Hormone Releasing Factor-40.

Experiment B: Determination of Preculture Optimal Duration

Experiment C: Effects of Culture Conditions on Basal and Human Pancreatic Growth Hormone Releasing Factor-40 Stimulated Immunoassayable Growth Hormone Secretion

Experiment D: Determination of Growth Hormone Stability in Culture Media. 
Experiment E: Validation of Cell Separation Procedure Single Phase Method

Experiment F: Validation of Cell Separation Procedure 2 Phase Method

Experiment G: Type One and Type Two Somatotroph

Response to Rat Growth Hormone Releasing Factor-43

Experiment H: Effects of Bovine Serum Albumin Incubation on Cell Viability and Growth Hormone Secretion

Experiment I: Type One and Type Two Somatotroph

Response to Rat Growth Hormone Releasing Factor-43 and Somatostatin

Experiment J: Type One and Type Two Somatotroph

Response to Rat Growth Hormone Releasing Factor-43 and Somatostatin

III. RESULTS

Experiment A: Mixed Cell Bioassayable and Immunoassayable Growth Hormone Secretion in Response to Human Pancreatic Growth Hormone Releasing Factor-40

Experiment B: Determination of Preculture Optimal Duration

Experiment C: Effects of Culture Conditions on Basal and Human Pancreatic Growth Hormone Releasing Factor-40 Stimulated Immunoassayable Growth Hormone Secretion

Experiment D: Determination of Growth Hormone Stability in Culture Media 
Experiment E: Validation of Cell Separation Procedure -

Single Phase Method.

Experiment F: Validation of Cell Separation Procedure 2 Phase Method

Experiment G: Type One and Type Two Somatotroph

Response to Rat Growth Hormone Releasing Factor-43

Experiment H: Effects of Bovine Serum Albumin Incubation on Cell Viability and Growth Hormone

Secretion.

Experiment I: Type One and Type Two Somatotroph

Response to Rat Growth Hormone Releasing Factor-43

and Somatostatin

Experiment J: Type One and Type Two Somatotroph

Response to Rat Growth Hormone Releasing Factor-43

and Somatostatin

IV. DISCUSSION

V. SUMMARY AND CONCLUSIONS

Appendix A: Procedures for Preparation of Media and

Solutions

Bibliography 


\section{List of Figures}

Figure 1. The Effect of hpGRF-40 on BGH Release, on IGH Release, and on the BGH/IGH Ratio for Secreted GH

Figure 2. The Effect of Increasing Durations of Preculture of Mixed Somatotrophs on Basal and hpGRF-40 Stimulated BGH Release, and IGH Release During a 4-Hour Treatment Period.

Figure 3. The Effect of Increasing Durations of Preculture of Mixed Somatotrophs on Basal and hpGRF-40 Stimulated BGH Release, and IGH Release During a 4-Hour Treatment Period

Figure 4. The Effect of Various Culture Conditions on Basal and hpGRF-40 Stimulated IGH Release.

Figure 5. The Effect of Culture Duration on Degradation of Human Immunoreactive $\mathrm{GH}$

Figure 6. Secretion of Rat Immunoreactive GH from Mixed Rat Adenohypophyseal Cells Incubated in Culture Media Alone, or Media Containing $5 \mu \mathrm{g} \mathrm{hGH}$ per $\mathrm{mL}$

Figure 7. Immunoreactive Rat GH Secretion in Response to rGRF-43 in Mixed, Type 1, and Type 2 Cell Types

Figure 8. The Effect of 45-Minute Pituitary Cell Incubation in $1.078 \mathrm{~g} / \mathrm{mL}$ BSA on Subsequent Basal and rGRF-43Stimulated BGH and IGH Secretion During a 4-Hour Treatment Period in Media C Alone or Supplemented with GRF.

Figure 9. The Effect of 45-Minute Pituitary Cell Incubation in $1.078 \mathrm{~g} / \mathrm{mL}$ BSA on Subsequent Basal and rGRF-43Stimulated BGH and IGH Secretion During a 4-Hour Treatment Period in Media C Alone or Supplemented with GRF. 
Figure 10. The Effect of rGRF-43 and SRIF Treatment, Alone, and in Combination, on Secretion of BGH and IGH from Mixed, Type 1, and Type 2 Somatotrophs..........................................96

Figure 11. The Effect of rGRF-43 and SRIF Treatment, Alone, and in Combination, on Secretion of BGH and IGH from Mixed, Type 1, and Type 2 Somatotrophs..........................................106 


\section{List of Tables}

Table 1. Comparison of Two Types of Rat Somatotrophs...........................28

Table 2. The Effect of 4-Hour GRF-Treatment on IGH

Production in Mixed Cells

Table3. BGH and IGH Secretion in Mixed, Type 1, and Type 2 Somatotrophs Cultured for 12 Days

Table4. BGH and IGH Secretion From 12-Day Cultures of Mixed, Type 1, and Type 2 Somatotrophs Expressed on a Per Cell Basis

Table5. BGH and IGH Secretion From 12-Day Cultures of Mixed, Type 1, and Type 2 Somatotrophs Expressed on a Per Somatotroph Basis

Table6. Bioassayable and Immunoassayable Growth Hormone Secretion in Response to Rat Hypothalamic GRF-43

Table 7. Maximal rGRF-43-Stimulated Percent-Increase

Table 8. Secretion of BGH and IGH from Mixed, Type 1, Type 2 Somatotrophs in Response to rGRF-43 and SRIF Treatment, Alone and in Combination

Table 9. Growth Hormone Secretion from rGRF-43-Treated

Somatotrophs Expressed as a Percent of Control Secretion

Table 10. Growth Hormone Secretion from SRIF-Treated Somatotrophs Expressed as a Percent of Control Secretion

Table 11. Growth Hormone Secretion from Somatotrophs

Treated with Combinations of rGRF-43 and SRIF

Expressed as a Percent of Control Secretion

Table 12. Secretion of BGH and IGH from Mixed, Type 1, and Type 2 Somatotrophs in Response to rGRF-43 and SRIF Treatment, Alone and in Combination 
Table 13. Growth Hormone Secretion from rGRF-43-Treated

Somatotrophs Expressed as a Percent of Control Secretion

Table 14. Growth Hormone Secretion from SRIF-Treated

Somatotrophs Expressed as a Percent of Control Secretion

Table 15. Growth Hormone Secretion from Somatotrophs

Treated with Combinations of rGRF-43 and SRIF

Expressed as a Percent of Control Secretion 


\section{Abstract}

The rat pituitary contains at least 2 distinct populations of somatotrophs. These cells secrete growth hormone (GH) with different activities as measured by radioimmunoassay (RIA), and as measured by tibial bioassay (BA). Type 1 somatotrophs (density $1.050-1.070 \mathrm{~g} / \mathrm{cc}$ ) secrete $\mathrm{GH}$ with a low BA/RIA ratio. By contrast, type 2 somatotrophs (density 1.071-1.084 g/cc) secrete $\mathrm{GH}$ with a high BA/RIA ratio. Rat plasma bioassayable $\mathrm{GH}(\mathrm{BGH})$ is elevated and immunoassayable $\mathrm{GH}(\mathrm{IGH})$ relatively unchanged in response to stresses, suggesting a differential regulation of these two cell types. The main purpose of this study was to determine if rat GRF and SRIF selectively regulate secretion of IGH and BGH from these two cell types. In order to test that hypothesis, pituitary cells were separated into 2 populations on density gradients. Mixed, type 1 , and type 2 cells were then cultured $(4 \mathrm{~h})$ in the presence of GRF, SRIF, or GRF + SRIF. Media were assayed by both RIA and BA and data were expressed as $\mathrm{ng} \mathrm{GH}$ per 1000 somatotrophs. The experiment was reproduced with essentially identical results. Data verified that in untreated cells BGH is the major form of hormone secreted by type 2 cells, which secrete 3-5 times more BGH than type 1 cells. GRF stimulated secretion of both BGH and IGH by both cell types. Treatment with SRIF inhibited BGH and IGH secretion $41-68 \%$ in type 1 cells and IGH secretion in type 2 cells, whereas SRIF doses as high as $10 \mathrm{nM}$ did not inhibit secretion of BGH by type 2 cells. Most importantly, combined treatments with GRF and SRIF produced a 
shift in the $B G H / I G H$ ratio for secreted $G H$. The shift differed depending upon cell type. In mixed and type 2 cells the combined treatments favored release of BGH, while in type 1 cells $B G H$ was undetectable during these treatments. The fact that BGH and IGH secretion from type 1 and type 2 somatotrophs was reflected in the mixed cell data was the apparent result of differences in regulation of the two cell types. Since there is evidence that both SRIF and GRF are released during environmental stress in rats, these results could explain the relatively greater release of BGH vs. IGH observed during stress in rats. 


\section{INTRODUCTION AND LITERATURE REVIEW}

Over the past seven decades researchers have made considerable progress toward understanding the chemistry and physiology of growth hormone (GH). Since the reports of the first reliable assays for GH (all bioassays) in the late 1930's, a major form of GH has been purified from pituitaries, sequenced, and used in the production of antisera for specific immunoassays. The availability of purified GH has made possible the careful study of GH variants and fragments enriched or depleted of growth-promoting activity. Purified GH has also been used extensively to study the direct and indirect effects of $\mathrm{GH}$ on various tissues. The availability of specific antisera has reduced the amount of GH required for assay by about a thousand-times, and made it possible to rapidly identify GH or GH-like molecules in nitrocellulose trans-blots of electrophoretic gels and in chromaíographic eluents. More recently, GH antisera has been used for definitive identification of pituitary somatotrophs. The success in GH research since the advent of the immunoassay in the early 1960's has been quite rapid and profitable, but two important, and as yet unresolved probiems appear to have been overlooked: 1) the ratio of GH activity measured by tibial bioassay to that measured by radioimmunoassay (RIA) ranges from 1 to $>400$ depending upon sampling site, and 2) under certain physiological conditions there is selective release of GH with activity in the tibial bioassay and relatively little activity in the immunoassay. This literature review presents evidence that there 
are at least 2 forms of $\mathrm{GH}$ that can be independently released. The evidence that the variants are released from 2 different somatotroph cell types is also discussed. Finally, the experimental hypothesis that the 2 somatotroph types are differentially controlled by the hypothalamic regulatory peptides, somatostatin (SRIF) and growth hormone releasing factor (GRF) is presented.

\section{A Note on Nomenclature}

There is much inconsistency in terminology found in published literature relating to this thesis. The major growth-promoting protein of the pituitary has been variously called somatotrophin (STH), somatotropin (STH), and growth hormone (GH). In this thesis this protein will be referred to as $\mathrm{GH}$. Similarly, the regulatory protein which stimulates $\mathrm{GH}$ release has been called somatoliberin, growth hormone releasing hormone (GRH), growth hormone releasing factor (GRF), somatotropin releasing hormone (SRH), somatotropin releasing factor (SRF), and somatocrinin. This protein will be referred to as GRF since this term is most frequently used in recent reports. The $\mathrm{GH}$ release inhibiting peptide, somatostatin, has been called growth hormone release inhibiting hormone (GH-RIH), and somatotropin release inhibiting factor (SRIF). The latter term will be used in this thesis. 


\section{Measurement of GH}

The presence of $\mathrm{GH}$ or a growth-promoting substance was originally surmised from the existence of giants, acromegalics, and dwarfs [34]. Hypophysectomy of rats and other animals produced failure of skeletal growth and weight gain [34]. Experiments involving injection of alkaline pituitary extracts into hypophysectomized rats to restore growth indicated that the pituitary is the source of GH [34]. In several early studies, injection of pituitary homogenates restored growth following hypophysectomy [34]. In 1935 bovine GH was partially purified [59]. The availability of partially purified GH made it possible to establish bioassays based on various physiological effects of $\mathrm{GH}$ such as body weight increase, tail-length increase, widening of tibial epiphyseal cartilage, organ weight increase (e.g. thymus), change in nitrogen balance, mobilization of fatty acids from adipose tissue, and diabetogenic effects [58]. The tibial assay method of Greenspan, et al. [33], using purified $\mathrm{GH}$, has been the most widely used bioassay procedure to date. It involves the administration of standard amounts of $\mathrm{GH}$ (typically ranging from 5 to $45 \mu \mathrm{g}$ of a highly purified hormone) to 35-44 day old hypophysectomized female rats over 4 days. Typically the rats are hypophysectomized at 26 days of age. When the tibia is removed, longitudinally sectioned, stained, and measured via ocular micrometry the log of the total dose plotted versus the mean tibial epiphyseal cartilage width gives a linear dose-response relationship over a broad range. 
The assay is generally considered to be specific for $\mathrm{GH}$, though thyroxine exerts a synergistic effect, and adrenocorticotropin has an inhibitory effect on tibial growth [58]. Simultaneous daily doses of $0.25 \mu \mathrm{g}$ of thyroxine and $6.25 \mu \mathrm{g}$ of bovine $\mathrm{GH}$ caused a significant increase in tibial width from the $\mathrm{GH}$ alone controls [58]. The inhibitory effects of adrenocorticotropin are not apparent with doses as high as $25 \mu \mathrm{g}$ per day [58] and for this reason should be considered insignificant. Moreover, adrenocorticotropin is rapidly destroyed in blood and media.

Controversy has surrounded the issue of whether the tibial growth response is due to a direct $\mathrm{GH}$ effect, or is mediated by circulating somatomedins. Grindeland et al. [35] injected somatomedin A over the 4 day assay period at a dose of 450 units 1 and did not observe significant growth relative to saline controls. However, Schoenle et al. [94] found significant increases in tibial epiphyseal width with $43 \mu \mathrm{g} /$ day doses of IGF-I (insulin-like growth factor-I), and $131 \mu \mathrm{g} /$ day doses of IGF-II (insulin-like growth factor II). These are relatively large "pharmacological" doses of IGF, and probably never occur physiologically. Isaksson et al. [46, 47] showed that direct epiphyseal injections of $10 \mu \mathrm{g}$ of $\mathrm{GH}$ on days 14,16 , and 18 post-hypophysectomy produced a highly significant increase in the tibial epiphyseal width as compared to the saline injected control epiphysis on the opposite leg of the same animals.

\footnotetext{
1One unit of somatomedin is equal to $1 \mathrm{~mL}$ of normal serum activity. The somatomedin used was a Kabi (Stockholm, Sweden) preparation.
} 
This experiment suggests that $\mathrm{GH}$ can directly stimulate longitudinal bone growth. It may be that $\mathrm{GH}$ initiates local production of IGF-I, as it has been shown that antisera to IGF-I blocks $\mathrm{GH}$-induced collagen synthesis in neonatal calvarial osteoblast-like cells [26]. Despite potential interference from some of the agents mentioned, the tibial bioassay of $\mathrm{GH}$ appears highly specific to $\mathrm{GH}$. Indeed, in a 1977 review on $\mathrm{GH}$ bioassay, $\mathrm{Li}$ [58] concluded by stating: "It appears that procedures involving biological assay will continue to be essential for the detection of GH activity, and it seems certain that they will never be replaced entirely by immunological methods in endocrinological research."

In 1966 the RIA for rat GH was first reported [89]. The antisera used in the immunoassay are raised against $\mathrm{GH}$ obtained primarily from the pituitary granule fraction. The availability of specific antisera has reduced the amount of GH required for assay by about a thousand-times, and made it possible to rapidly identify $\mathrm{GH}$ or GH-like molecules in nitrocellulose trans-blots of electrophoretic gels and in chromatographic eluents. While the thousands of GH physiology research papers since 1964 attest to the significance of the immunoassay, it has become apparent through diligent use of the tibial bioassay that the immunoassay does not measure all forms of circulating $\mathrm{GH}$. If some $\mathrm{GH}$ is modified upon or after secretion, is covalently or non-covalently polymerized, or is released through a pathway which bypasses the secretory granules, then it is possible that variants could exist and it is possible that 
the antisera used in current immunoassays does not detect all $\mathrm{GH}$ forms. Indeed, there is evidence, to be discussed below, that all of the aforementioned processes occur in the rat. The presence of $\mathrm{GH}$ variants would, perhaps, be of little interest if all forms were coreleased and had equivalent biopotency. However, as will be described in the section on GH variants, this is not the case.

The late 1960's through the early 1970's was a period of great excitement in biological research. Using the immunoassay it was possible to readily measure numerous biomolecules which could previously be measured only with great difficulty in biological samples. Soon a flood of reports on various aspects of $\mathrm{GH}$ physiology appeared in the journals, accelerated in part by the rapidity with which results could be obtained. Perhaps fueled by the great excitement over the new assay procedure, a widespread partiality in favor of the immunoassay emerged. In the face of discrepancies between immunoassay and bioassay results (to be discussed below) most researchers either a) assumed equivalence between GH measured by tibial assay (BGH) and $\mathrm{GH}$ measured by immunoassay (IGH), or b) favored the immunoassay results over the bioassay results. Malacara, et al. [62] failed to detect depletion of IGH from rat pituitaries following injection of the equivalent of extracts of 25 hypothalami, though significantly lesser amounts had been shown to deplete $\mathrm{BGH}$. They summarized the prevailing attitude when they stated that "...we would interpret the results of the present experiment to mean that when an authentic growth 
hormone releasing factor is identified, it will cause a discharge of immunoassayable $\mathrm{GH}$ into the blood with or without an associated depletion of immunoassayable GH content of the pituitary." It appears that they implicitly considered bioassay results to be insignificant. The researchers went on to criticize the results of Schally et al. [92] who reported a decapeptide with $\mathrm{GH}$ releasing activity as measured by bioassay, but inconsistently measurable by immunoassay. More will be said about these discrepancies below; the goal here is to introduce the reader to a prevalent bias within the literature. In spite of this bias, studies of GH using only RIA have provided a tremendous amount of useful information. The GH RIA has been an invaluable tool.

\section{The Hypothalamic-Pituitary Axis In the Control of GH Release}

It is now dogma that hormone-secreting cells of the anterior pituitary are regulated directly by polypeptides or monoamines released from the hypothalamus. Numerous experimental observations have led to the view that hypothalamic releasing factors are secreted into the hypothalamic-pituitary portal vessels following integration of neural and metabolic signals, and that cells of the pituitary are subjected to high concentrations of these factors which stimulate or inhibit specific hormone release. Transection of the pituitary stalk or placement of a barrier between the pituitary and hypothalamus causes atrophy of the pituitary [41], 
while revascularization restores normal morphology and hormone secretion [41]. Wislocki and King [115] were the first to report that blood in the hypothalamic portal vessel flows from the hypothalamus to the anterior pituitary. Known release-inhibiting, or releasing factors, are found in the highest concentrations in the portal blood, as indicated by studies involving in vitro incubation of hemipituitaries with portal or peripheral plasma followed by assay for pituitary hormones [75]. Microcannulation of the portal vessels of rats [76] has made it possible to administer hypothalamic extract (HE) or putative secretagogues in vivo, thus bypassing the hypothalamus. These studies have shown that hypothalamic regulatory factors directly regulate hormone release from the anterior pituitary [75]. Fluorescein dye-linked antibodies or enzyme-conjugated antibodies to releasing factors have been used to localize hypothalamic cell bodies responsible for secretion of these factors. Antisera to a recently isolated GRF has been used to localize GRF neurosecretory cell bodies in the arcuate nucleus [11]. Lesions in the arcuato nucleus significantly reduce basal plasma IGH levels [63]. In addition to factors of the hypothalamic-pituitary axis, other substances control pituitary hormone release. With GH it has been shown that somatomedin C (IGF-1), which is primarily derived from the liver, stimulates hypothalamic somatostatin release, and directly (but more slowly) inhibits IGH release from the pituitary [8]. 


\section{Studies with Hypothalamic Extracts}

As with other studies of hypothalamic regulatory peptides, the first studies of $\mathrm{GH}$ regulation utilized $\mathrm{HE}$ to determine the presence of releasing factor(s). Deuben and Meites first showed that in 6-day cultures of rat pituitary explants, addition of an acid extract of the hypothalamus significantly increased release of BGH into the medium [22]. Other researchers reported similar results using rat HE and tibial assay in in vitro studies of various duration [85] and in vivo studies with rat $\mathrm{HE}[70]$, guinea pig $\mathrm{HE}[64,48]$ and beef $\mathrm{HE}$ [48]. In vitro studies have used pituitary explants sectioned into halves, quarters, or eighths, or they have used dissociated pituitary cells. In vivo studies have typically involved systemic venous or carotid arterial injections of HE. Radioimmunoassay has yielded similar, but sometimes conflicting results [61]. In vivo injections of porcine HE in rats caused release of IGH $[61,62]$. Porcine, ovine, and human HE have been shown to cause release of IGH when injected in vivo into female Rhesus monkeys [50]. Russell, et al. [84], using both RIA and tibial assay found that HE from hypophysectomized rats stimulated the release of $\mathrm{BGH}$ from rat adenohypophyses 2 to 2.75-times, whereas RIA showed increased GH secretion by HE in only 2 of 4 experiments and to a lesser degree (1.4 to 1.6-times). It should be noted that most in vivo studies of $\mathrm{BGH}$ have used depletion of pituitary BGH as an index of release. It should also be noted that Malacara et al. [62] had to estrogenprogesterone "prime" their rats in order to observe a significant 
effect in response to in vivo injection of 10 and 25 hypothalamic equivalents (one hypothalamic equivalent equals the extract from one hypothalamus).

These early reports clearly indicate the presence of GRF in $H E$, but they are important to reexamine for other reasons. The results of Russell, et al. [84] demonstrate that HE causes greater release of $B G H$ than $I G H$, thus suggesting that some species of $\mathrm{GH}$ may not be detectable by RIA. The collective in vivo and in vitro studies of $\mathrm{BGH}$ release indicate that the pituitary depletion method can reflect release of $\mathrm{GH}$ into culture media. Moreover, Parkhie, et al. [70] found a linear log-dose relationship in a 6-point in vivo assay using 6 doses of $\mathrm{HE}$, offering further support for the validity of the depletion method, and countering some of the criticisms of the depletion method $[78,81]$. There are 2 principal reasons why researchers have relied upon the depletion assay; 1) large volumes of plasma are required in order to obtain enough $\mathrm{GH}$ for detection by tibial bioassay, and 2) exposure of plasma to glassware causes some conversion which renders it toxic to recipient animals [35]. The latter problem can be remedied by siliconizing glassware [35]. Indeed, much of the criticism of depletion methods can be explained by not assuming that all GH with bioactivity possesses immunoreactivity with antisera raised against pituitary granulederived $\mathrm{GH}$, or by assuming that there are potency differences amongst GH variants. These possibilities are discussed below. 


\section{Studies with Purified GRF}

The early work with hypothalamic extracts inevitably led to attempts at isolating the active GRF. Excellent reviews of this work are available [30, 40, 107]. Some of the earliest notable results were those of Sawano et al. [87]. Working with a GRF purified from porcine hypothalami and later shown to be a decapeptide [91], they demonstrated that intracarotid injection of 4 $\mu \mathrm{g}$ of this GRF in rats caused a significant pituitary depletion and corresponding plasma elevation of BGH [87]. This was later replicated using smaller doses. It was shown that intracarotid injections of as little as $80 \mathrm{ng}$ would cause significant pituitary depletion, while $400 \mathrm{ng}$ would cause a significant plasma elevation of BGH [67]. In other work it was shown that injection of the decapeptide caused a significant lowering of piasma IGH and a significant elevation of plasma BGH 15 minutes after injection in rats. The pituitary depletion was in excellent quantitative agreement with the plasma elevation [109]. In similar in vitro work with hemipituitaries using RIA, tibial assay, and incorporation of ${ }^{35} \mathrm{~S}$ into costal cartilage (as assays) corresponding in vivo results were not consistent. However, increasing doses of the decapeptide, both natural extract-derived and synthetic, generally caused a significant release of $\mathrm{BGH}$ with little or no effect on IGH release [91]. Other in vitro experiments have demonstrated that the decapeptide stimulates IGH release, though the effect on BGH is greater [110]. Schally has reported that the GRF was highly 
effective in promoting the in vitro release of BGH but relatively inactive in stimulating the release of $I G H$, an effect which should cause the secreted $\mathrm{GH}$ to have a high $\mathrm{BGH} / \mathrm{IGH}$ ratio [91]. As already mentioned, a bias that $B G H$ is equivalent to $I G H$ was clearly prevalent at this time. The failure of Schally's decapeptide to consistently release IGH caused most researchers to disregard this "GRF" as insignificant or artifactual and to search for other factors. In 1982 a human GRF was isolated from a pancreatic tumor in a patient exhibiting symptoms of acromegaly [79]. The major protein obtained was sequenced and shown to consist of 40 amino acid residues, while minor fractions contained 37 and 44 residues. The GRFs were synthesized using solid phase technology and tested in cell culture. Maximal response doses as low as $0.1 \mathrm{nM}$ resulted in an 8-times increase in the release of IGH relative to controls. Antisera to the 40 residue GRF has been used to localize immunoreactive cell bodies in the arcuate nucleus of the rhesus monkey hypothalamus. In the rat, lesions in this area impair [11, 28], and electrical stimulation increases [28] IGH release. In 1983 a rat GRF was isolated from a pool of 80,000 hypothalami [100]. As with human GRF it has been sequenced, synthesized, and tested in cell culture. The rat GRF has 43 amino acid residues, has $70 \%$ sequence homology to human GRF-40 (hGRF-40), and is similar in potency to hGRF-40 in cell culture. The GRF has been localized to the arcuate nucleus of the rat hypothalamus using immunocytochemical methods [63]. Since the original discoveries, 
numerous studies have verified the specificity of these GRFs for GH release. The experimental animal used has typically been the rat, though clinical trials in humans are now underway. The results of the original research have been verified in numerous in vitro studies $[2,9,13,12,15,18,95,100,108,111]$ and in vivo studies $[16,112$, reviewed in 30]. Clearly hGRF-40 and rGRF-43 are physiologically important peptides along with somatostatin, the $\mathrm{GH}$ release inhibiting peptide (14 residues) in control of $\mathrm{GH}$ secretion. However, to date there are no publications citing the effects of these GRFs on the release of BGH. This is unfortunate considering the discrepancies between assay systems mentioned above.

\section{Somatostatin}

The cyclic tetradecapeptide, somatostatin, was originally isolated from ovine hypothalami during the search for the hypothetical GRF [14]. It was subsequently isolated from porcine hypothalami, and its sequence was shown to be identical to ovine somatostatin [93]. During the process of purification, SRIF was measured in various fractions by in vitro bioassay based on the inhibition of release of IGH. It is now synthesized using solid phase methods [80]. Several reviews have summarized the numerous effects of SRIF including inhibition of GH release, inhibition of insulin release, inhibition of thyroid stimulating hormone (TSH) release, as weli as numerous effects on the gastrointestinal tract $[71,93]$. It is evident that SRIF is physiologically important in the 
regulation of $\mathrm{GH}$ release since in vivo administration of antiserum to SRIF causes an elevation of plasma IGH $[1,105,106]$. Somatostatin suppresses both basal and GRF-stimulated IGH secretion in vitro [9, $51,108]$. It has been shown in in vitro perifusion studies that SRIF withdrawal causes a short-lived burst of IGH release $[51,101]$. The amplitude of the burst is increased with addition of GRF [51] and with increasing SRIF concentrations [101]. The effects of SRIF on the release of $\mathrm{BGH}$ either in vivo or in vitro have not been determined.

In rats, "stress" causes an inhibition of IGH release as will be described in the next section. Since SRIF decreases IGH secretion in vitro to levels below control secretion, SRIF secretion is probably increased during stress in rats. More direct evidence in support of the aforementioned comes from studies in which SRIF antiserum was injected prior to stress. Injection of SRIF antiserum caused reversal of stress-induced IGH suppression due to i.p. injection of saline (used as a stressor) [106], 30 minutes forced swimming [106], 72-hour fasting [105], bleeding [1], and electroshock [1]. These findings suggest that increased hypothalamic SRIF release occurs during stress in the rat. Though BGH was not measured in the experiments described above, it seems likely that BGH and IGH release are differentially affected by SRIF alone, or in combination with GRF, since it has been shown indirectly that hypothalamic GRF release is also increased following stress in rats [49, 53; see next section]. 


\section{Growth Hormone Release During Stress, Hypoglycemia, and Spaceflight}

In various in vivo "stress" conditions there have been discrepancies between GH immunoassay and bioassay results. This has included both hypothalamic extract and GRF injections (see above). In these studies "stress" is defined as exposure to cold, fasting, and insulin-induced hypoglycemia, spaceflight, and various pathological disease states in humans.

In primates cold exposure, fasting, insulin-induced hypoglycemia, and administration of 2-deoxyglucose produce elevation of plasma IGH $[32,82,83,88,90]$. This is not the case with rats, however. Using the pituitary depletion method and the tibial assay, BGH has been shown to be depleted (as much as $35 \%$ ) under a variety of stresses to rats including 30-60 minutes exposure to cold [54], fasting [54], insulin-induced hypoglycemia $[52,68,104]$ and administration of 2-deoxyglucose [104]. Pecile et al. [72] provided an excellent review of the numerous studies demonstrating $\mathrm{BGH}$ release during stress in rats, and the associated release of GRF from the hypothalamus. Muller, et al. [66] reviewed secretion of BGH and IGH. Their review contains an excellent discussion of several studies demonstrating BGH, but not IGH pituitary depletion during stress, and failure to detect elevated plasma IGH during stress. The phenomenon has also been observed in hypoglycemic or cold-stressed guinea pigs, but not in mice [65]. 
Similar depletion has not been detected by immunoassay $[19,35,66$, 90, 104]. Though fewer investigations of plasma GH have been done, it has been shown that cold-stress or insulin-iiicluced hypoglycemia cause a significant plasma BGH elevation [24] and no elevation (or a decrease) of plasma IGH concentration [19, 24, 29, 35].

Hypoglycemia has been shown to cause release of GRF into the blood of hypophysectomized rats. These studies used injection of plasma of experimental animals into the assay test animals with subsequent pituitary depletion bioassay after 30 minutes [53]. This indicates that the stress (hypoglycemia) effects are probably mediated by releasing factor activity. This interpretation has been confirmed by bioassay of pituitary homogenates of rats treated with HE from hypoglycemic rats [49]. While the pituitary depletion assay has been criticized due to occasional inconsistent results or failure of plasma IGH elevation in the presence of pituitary BGH depletion $[20,77]$, the aforementioned results are understandable if one does not assume an equivalence of BGH to IGH. Chemical studies, to be discussed below, indicate that the two are different.

An unusual opportunity for study of $\mathrm{GH}$ regulation has emerged with the onset of modern spaceflight and its host of associated physiological problems. In light of reports of bone and muscle loss following spaceflight of 7-days duration, the $\mathrm{GH}$ system has been the subject of intensive investigation. Seven days of spaceflight produced a significant elevation of intracellular (somatotroph) IGH concentration [37]. When flight pituitary cells were implanted into 
the brain ventricles of hypophysectomized recipient rats there was decreased growth over a 2 week period relative to control animals. Most important, however, is the observation that following high pressure liquid chromatography (HPLC) fractionation of 6 day pituitary cell culture media, it was found that the flight cells released significantly less of a large molecular weight $(\approx 100 \mathrm{kD}) \mathrm{GH}$ variant rich in biological activity, but relatively devoid of immunoactivity. Whatever the source of regulation, it appears that release of this large molecular weight variant was preferentially impaired. This could, in part, account for bone loss and muscle atrophy.

\section{Plasma GH Concentrations and Unique Cell Culture Experiments}

In a recently completed study by Bauman and Grindeland [5] human plasma BGH and IGH determinations were made under several conditions; normal resting, hypophysectomized, deep sleep (stage 4), GRF-treated, DOPA-treated, and acromegaly. The BGH values $(\mathrm{ng} / \mathrm{mL})$ presented in the above respective order were: $<100$ to 780 ; undetectable; $<333$ to $825 ; 667$ to $5200 ; 500$ to 540 ; and 2020 to 2965. The corresponding IGH values $(\mathrm{ng} / \mathrm{mL}$ ) were: 8.1 to 10.2; undetectable; 15 to $63 ; 5$ to 11 ; and 28 to 132 . No correlation was found between BGH and somatomedin C or somatomedin A. Evaluation of the percentage increase and absolute increase over normal GH levels in the DOPA and GRF-treated subjects (not shown) 
revealed that these treatments produced a much larger percentage increase for IGH secretion than for BGH secretion. However, in terms of absolute amounts of $\mathrm{GH}$, the above treatments are more potent for BGH secretion. These data are suggestive of differential regulation of $\mathrm{BGH}$ and IGH secretion in humans.

Plasma $\mathrm{BGH} / \mathrm{IGH}$ ratios in humans have been reported to be about 200:1 in normal subjects [24, 23], while the value ranges from $30-400: 1$ in rats, depending upon sampling site $[23,25,109]$. Measurements of granular (somatotroph) and pituitary homogenate GH have consistently revealed a BGH/IGH of $1[23,35,110]$. Measurements of pituitary cytosol fractions yield a $\mathrm{BGH} / \mathrm{IGH}$ ratio of 1.7 while measurements in media from dissociated, cultured mixed cells indicate that the ratio increases to 2 or slightly greater $[23,110]$. The increases in the ratio of $B G H / I G H$ have been interpreted by some researchers as evidence that $\mathrm{GH}$ is modified upon secretion [110]. A recent study by Grindeland and Hymer [36] indicated that the highest obtainable $\mathrm{BGH} / \mathrm{IGH}$ ratio for secreted $\mathrm{GH}$ was about 5 in purified somatotrophs. This reported ratio is significantly lower than the plasma ratios mentioned above. It is most likely that $\mathrm{GH}$ is not only modified upon secretion, but also after secretion. The work of Grindeland and Ellis [35] has shown that the tibial growth response to injections of $\mathrm{GH}$ in hypophysectomized rats could be blocked with trasylol injections (a broad-spectrum proteolytic inhibitor of trypsin like enzymes). Growth responses due to injections of native bovine and native rat 
GH could be blocked with trasylol, whereas no inhibitory effect on growth was observed following injection of plasmin-degraded rat $\mathrm{GH}$ or plasma from intact rats. Similar results were found by Vodian and Nicoll [110]. These results indicate that rat tibial growth is due to a $\mathrm{GH}$ form which differs from native rat $\mathrm{GH}$ isolated from the pituitary. The results of Grindeland and Ellis [35] and Vodian and Nicoll [110] also indicate that some transformation of GH occurs at an extrapituitary site, and offer an explanation of why the $B G H / I G H$ ratio for secreted $\mathrm{GH}$ is significantly lower than plasma levels.

\section{Chemical Studies of GH Variants}

There have been numerous studies on the chemical nature of $\mathrm{GH}$ variants. The methods employed are diverse and include HPLC, electrophoretic techniques, affinity and gel chromatography, and immunological techniques. While it is unfortunate that BGH has been neglected, good reviews on human $\mathrm{GH}$ are available [56, 57]. A truly comprehensive review of this literature would be extremely lengthy, and is beyond the scope of this thesis. Nevertheless, it is worthwhile to mention select studies which demonstrate the complexity of the GH system.

Recent experiments have indicated that a $22 \mathrm{kD}$ phosphorylated form of $\mathrm{GH}$ [60] and a 26-27 kD glycosylated form of $\mathrm{GH}$ [97] is synthesized and released by rat pituitary glands. Western blot analysis of 2-dimensional polyacrylamide gels has indicated 
the presence of about 20 different immunoreactive forms (or fragments) of $\mathrm{GH}[43,117]$. The physiological implications of these results are unclear at present. Some immunoreactive species may represent biologically inactive fragments resulting from degradation. Interpretations of plasma studies are now complicated by the recent evidence for a serum binding protein specific for $\mathrm{GH}$ $[3,4,55]$.

Ellis and Grindeland have shown that plasma human $\mathrm{GH}$ with a high $\mathrm{BGH} / \mathrm{IGH}$ ratio $(490-680)$ elutes in a position indicative of a large molecular weight protein ( $>100 \mathrm{kD}$ ) following gel chromatography [23]. This has been independently verified in human pituitary extracts using HPLC [44]. The large M.W. human protein(s) with high BGH/IGH activity is/are essentially devoid of prolactin activity, whereas the classic 22 kD human GH possesses about 4 international units of prolactin activity per milligram [43].

Following affinity chromatography on a column prepared with antiGH sera, Grindeland et al. [35] have shown that considerable growthpromoting activity is still present when the eluate is measured by tibial assay. They have also shown that the growth of young, normal rats cannot be suppressed by antisera to immunoassayable pituitary granule-derived GH [23]. It appears that a significant proportion of the pituitary-derived growth-promoting activity in plasma does not react with $\mathrm{GH}$ antisera.

Russell et al. [85] processed media and tissue from pituitary explants by polyacrylamide discontinuous gel electrophoresis, and 
analyzed eluates for BGH and IGH. They found that in the tissue 80$99 \%$ of the $\mathrm{GH}$ was found in segments with an Rf range of 0.3-0.6, whereas in the media, both assays recorded a more cathodal distribution of most of the hormone (85-96\%) in the Rf region 0.00 0.42 . The tissue contained $\mathrm{GH}$ that had a high $\mathrm{BGH} / \mathrm{IGH}$ ratio (11.125.7; Rf 0-0.29), whereas the media contained $\mathrm{GH}$ with an even higher ratio (32.7-33.8; $\mathrm{Rf}$ 0.57-0.68). These results indicate that $\mathrm{GH}$ exists in electrophoretically heterogeneous forms which differ in $\mathrm{BGH} / \mathrm{IGH}$ activity ratios and that the $\mathrm{BGH} / \mathrm{IGH}$ ratio increases as $\mathrm{GH}$ leaves the intracellular compartment.

Stachura et al. [102] have shown that at least two pools of $\mathrm{GH}$ exist; a storage pool, and an early release pool which is not stored. The results were obtained through use of a double pulse-labeling method in in vitro perifusion experiments. The first label, administered for 2 hours prior to the second label, was ${ }^{14} \mathrm{C}$-Leucine, while the second label ( $1 \mathrm{hr}$ later) was ${ }^{3} \mathrm{H}$-Leucine. Collection of eluate began immediately after the second label. Following gel chromatography (Sephadex G-200) of dialyzed perifusion eluates, they found different results for the 0-40 minute than for the 80-120 minute eluates. At both times ${ }^{14} \mathrm{C}-\mathrm{GH}$ eluted at approximately $25 \mathrm{kD}$, while in the $0-40$ minute fraction ${ }^{3} \mathrm{H}-\mathrm{GH}$ eluted at 40-45 kD. In the 80-120 minute fraction there was an emergence of a $25 \mathrm{kD}{ }^{3} \mathrm{H}-\mathrm{GH}$ peak. The $40 \mathrm{kD}$ form is not simply a dimer, as some $40 \mathrm{kD}{ }^{14} \mathrm{C}-\mathrm{GH}$ would have been observed in the $0-40$ minute eluate, but was not. The results demonstrate the presence 
of more than one path for $\mathrm{GH}$ release, each path releasing a different $\mathrm{GH}$ form.

While the results of Stachura et al. indicate that at least one large molecular weight form of $\mathrm{GH}$ is not a dimer, other studies have indicated that some polymerization occurs. Stolar et al. [103] found that immunoreactive forms of $\mathrm{GH}$ with $\mathrm{Mr}$ (relative molecular weight) of $45,62,80$, and $110 \mathrm{kD}$ in SDS-PAGE (sodium dodecylsulfate polyacrylamide gel electrophoresis) could be nearly $100 \%$ converted to $22 \mathrm{kD}$ (major) and $20 \mathrm{kD}$ (minor) forms with sulfhydryl reduction. Beitins et al. [6] found that injection of radiolabeled monomeric $22 \mathrm{kD} \mathrm{GH}$ into humans led to a near $100 \%$ conversion to larger molecular weight moieties (majority was $>100 \mathrm{kD}$ ). In vitro incubation in plasma produced a similar conversion, though the timecourse was slower. Incubation in serum albumin or gammaglobulin was without effect. Benviste et al. [7] have shown that mercaptoethanol treatment of large M.W. GH obtained from 2 human pituitaries resulted in a $60 \%$ conversion to $22 \mathrm{kD} \mathrm{GH}$. Further dissociation was obtained by combined treatment with the reducing agent plus urea. It appears that at least some of the larger M.W. GH is a result of interchain disulfide linkages. Whether or not this is a regulated process remains speculative. The interpretation of these results is difficult. The analysis has been complicated by the fact that very seldom does a researcher employ bioassay and immunoassay in the same experiment. Indeed, many researchers use affinity chromatography to purify $\mathrm{GH}$ used in their chemical studies. 
The probability that non-immunoreactive forms of $\mathrm{GH}$ are removed during these procedures is very real in light of the studies of Grindeland et al. (40, see above) which indicated that considerable growth promoting activity is not retained by $\mathrm{GH}$ affinity columns. The apparent inability of $\mathrm{GH}$ antisera to react with some forms of GH should not be surprising in light of the fact that antisera is raised against pituitary $\mathrm{GH}$ where the $\mathrm{BGH} / \mathrm{IGH}$ ratio is approximately one. Further studies and replication of others using both assay procedures is necessary before the chemical nature of $\mathrm{GH}$ can be thoroughly understood.

While the biological significance of these $\mathrm{GH}$ variants remains unclear, differences in activities of variants at different tissues could, in part, be responsible for the diversity of physiological effects of GH including increased transport of amino acids across the plasma membrane of many cells, increased protein synthesis, mitosis of thymocytes, proliferation of chondrocytes and osteoblasts, and early hypoglycemic and delayed anti-insulin effects (such as hyperglycemia and mobilization of fatty acids from adipocytes). It has been reported recently that there are 2 classes of $\mathrm{GH}$ receptors in rat livers with $\mathrm{Kd}$ values of $8.0 \times 10^{-12} \mathrm{M}$ and 1.6 $X 10^{-12} \mathrm{M}$, and corresponding binding capacities of 4.34 and 12.4 femtomoles/mg protein, respectively [86]. The presence of more than one GH receptor type could be a means by which $\mathrm{GH}$ variants differentially mediate $\mathrm{GH}$ effects as postulated above. 


\section{Neurotransmitters and Regulation of GH Release}

Direct experimental evidence for differential regulation of the release of $\mathrm{GH}$ variants has been provided by Grindeland and his colleagues [39]. They used jugular and lateral brain ventricle cannulation of rats to inject (into ventricle) 5,10 , or $25 \mu \mathrm{g}$ of serotonin $(5 \mathrm{HT}), 5 \mu \mathrm{g}$ of dopamine (DA), or saline and collect plasma samples at 5, 15, 30, and 60 minutes via the jugular cannula. Saline had no effect compared to controls, while $5 \mu \mathrm{g}$ of $5 \mathrm{HT}$ depleted $25 \%$ of the intrapituitary BGH at 5 minutes, and $50 \%$ at 15,30 and 60 minutes. Dopamine depleted $50 \%$ of the hormone at all measured times. Plasma BGH concentration corresponded to the pituitary depletion. The only rise in plasma IGH values occurred 30 minutes after 5HT injection, which followed by 15 minutes the nadir of pituitary GH concentration. In another experiment using similar methodology, the results with $5 \mathrm{HT}$ and DA were replicated, but it was additionally found that $5 \mu \mathrm{g}$ of $5 \mathrm{HT}$ at time zero, followed by $5 \mu \mathrm{g}$ of DA at 15 minutes produced a $90 \%$ depletion of pituitary BGH in conscious normal rats. When the same experiment was done with intraventricular injections of noradrenergic agonists, there was approximately equal depletion of both BGH and IGH. These results suggest that two pools of $\mathrm{GH}$ exist which may correspond to different cell types (see below). In another experiment it was found that cold exposure or insulin injections had no effect on serum IGH, but significantly increased BGH concentrations with a concomitant decrease in pituitary BGH. This lack of effect on IGH in rats is in 
contrast to the observed elevation of IGH in humans during insulin injections or cold-stress. Cold exposure or insulin injections accompanied by intraventricular injections of a $5 \mathrm{HT}$ antagonist or DA antagonist produced different results. The DA antagonist completely blocked the rise in plasma $\mathrm{BGH}$ and the decrease in pituitary $\mathrm{BGH}$, whereas the $5 \mathrm{HT}$ antagonist had only a slight attenuating effect on $\mathrm{BGH}$ release. These results, as well as those mentioned earlier, indicate that some differential regulation of the release of BGH and IGH exists in the rat. They also indicate that the release of regulatory peptides governing release of $\mathrm{GH}$ variants is under differential neuronal control. It appears that the observed increases in plasma BGH during cold-stress and insulin injections is mediated by a dopaminergic system, even though activation of a serotinergic system increases $\mathrm{BGH}$ release in normal rats.

\section{Studies on Two Populations of Somatotrophs}

Insight into the mechanism of the presumed differential regulation of $\mathrm{GH}$ release was provided by the work of Snyder et al. [98, 99], Grindeland et al. [36] and Hymer [45]. In these studies dissociated pituitary cells were separated on the basis of density using a bovine serum albumin (BSA) density gradient procedure. In this scheme, $1.5 \mathrm{~mL}$ of cells plus media are applied directly on top of an upper layer of $1.5 \mathrm{~mL}$ of $1.071 \mathrm{~g} / \mathrm{mL}$ BSA, which resides above a $1.5 \mathrm{~mL}$ layer of $1.085 \mathrm{~g} / \mathrm{mL}$ BSA solution. The entire system is centrifuged for 30 minutes at $1000 \times \mathrm{G}$ at $4^{\circ} \mathrm{C}$. Centrifugation 
produces a pellet and two bands of cells at the solution interfaces. The bands are separately collected and the pellet discarded. The lower density cells $(1.050-1.070 \mathrm{~g} / \mathrm{mL})$ are called type 1 somatotrophs, while the higher density cells $(1.071-1.084 \mathrm{~g} / \mathrm{mL}$ ) are called type 2 somatotrophs. Numerous in vitro and in vivo studies have been done. The high density cells represent $55-65 \%$ of pituitary somatotrophs, are densely granulated, increase IGH secretion in response to thyroxine and CAMP but not dexamethasone, secrete hormone with a high $\mathrm{BGH} / \mathrm{IGH}$ ratio (4.5 in 4-day cultures), and are far more synthetically active than type 1 cells. By contrast, the type 1 cells are sparsely granulated but have an extensive endoplasmic reticulum and Golgi apparatus, increase secretion in response to dexamethasone and CAMP but not thyroxine, secrete hormone with a low BGH/IGH ratio (0.50 in 4-day culture), and are far less synthetically active than type 2 cells. Recently, Farrington and Hymer reported that when extracts of type 2 cells were treated with the reducing agent B-mercaptoethanol, there was a three to four-times increase in immunoactivity, whereas the same treatments were without effect on type 1 somatotrophs [27]. Preand post-reduction western blot analyses indicated that variants greater than $25 \mathrm{kD}$ were eliminated following reduction. Since reduction of culture media from type 2 cells also caused a 3-5times increase in immunoactivity, it was suggested that the variant released from type 2 cells is a large M.W. disulfide-linked aggregate of monomeric GH forms. The main differences between cell types 
are summarized in Table 1 . Since the type 2 somatotroph releases $\mathrm{GH}$ with a high $\mathrm{BGH} / \mathrm{IGH}$ ratio, it would seem that the selective release of $\mathrm{BGH}$ is mediated by this cell type. Indeed, when donor rats were subjected to $4^{\circ} \mathrm{C}$ for 30 minutes followed by dissociation and separation of pituitary cells, it was found that the only difference between control and cold-treated cells in 4-day cultures was that the release of $\mathrm{BGH}^{-}$from the type 2 cell was significantly less than controls [38]. The mechanism of hypothalamic control of this phenomenon is unknown. 


\section{TABLE 1}

\section{Comparison of Two Types of Rat Somatotrophs}

\begin{tabular}{|c|c|c|}
\hline & IYPE 1 & IYPE 2 \\
\hline Density $(\mathrm{g} / \mathrm{mL})$ & $1.050-1.070$ & $1.071-1.084$ \\
\hline Secretory Granules & Few & Many \\
\hline $\begin{array}{c}\text { Appearance } \\
\text { (transmission- } \\
\text { electron microscopy) }\end{array}$ & $\begin{array}{l}\text { Abundant Regions of } \\
\text { RER (rough endoplasmic } \\
\text { reticulum) and } \\
\text { Golgi Apparatus }\end{array}$ & $\begin{array}{l}\text { Few Regions of RER } \\
\text { and Golgi Apparatus }\end{array}$ \\
\hline $\begin{array}{l}\text { Dibutyryl cAMP } \\
\text { (3.0 mM) }\end{array}$ & $\begin{array}{l}\text { Stimulated IGH } \\
\text { Secretion }\end{array}$ & $\begin{array}{l}\text { Stimulated IGH } \\
\text { Secretion }\end{array}$ \\
\hline $\begin{array}{l}\text { Somatostatin } \\
\left(10^{-7} M\right)\end{array}$ & $\begin{array}{l}\text { Inhibited IGH } \\
\text { Secretion }\end{array}$ & $\begin{array}{l}\text { Inhibited IGH } \\
\text { Secration }\end{array}$ \\
\hline $\begin{array}{l}\text { Thyroxine } \\
\left(10^{-6} \mathrm{M}\right)\end{array}$ & No Effect & $\begin{array}{l}\text { Stimulated IGH } \\
\text { Secretion }\end{array}$ \\
\hline Hydrocortisone & Increased cell IGH & No effect \\
\hline
\end{tabular}

Adapted from Snyder et al. [99] 


\section{Summary}

Rats secrete two or more structural forms of growth hormone $(\mathrm{GH})$. One class of $\mathrm{GH}$, immunoactive $\mathrm{GH}(\mathrm{IGH})$, is detectable by immunoassays with antisera raised against $\mathrm{GH}$ purified from pituitary granules. A second class of $\mathrm{GH}$, bioactive $\mathrm{GH}(\mathrm{BGH})$, is measurable by the hypophysectomized rat tibial bioassay, and has low or no crossreactivity to the antisera used in the IGH radioimmunoassays. In rats, cold exposure, fasting, insulin-induced hypoglycemia, or administration of 2-deoxyglucose do not produce elevation of plasma IGH. Yet, when rat $\mathrm{GH}$ is measured by tibial bioassay it is found that the aforementioned stressors cause a significant depletion of pituitary BGH (as much as $50 \%$ ) and a corresponding elevation of plasma $\mathrm{BGH}$. The inability to detect increases in plasma IGH suggests that plasma $\mathrm{GH}$ in rats differs from pituitary granule $\mathrm{GH}$. The main reason for failure in rats to detect plasma IGH increases under these conditions is probably due to the fact that the antisera used in $\mathrm{GH}$ radioimmunoassays is raised against $\mathrm{GH}$ derived from the secretory granules of pituitary homogenates. In the pituitary granule fraction of rats the ratio of $\mathrm{BGH} / \mathrm{IGH}$ activities is about 1.0 , whereas in the nongranular cytosol fraction the ratio increases to 1.7 , and in pituitary cell culture media the ratio is as high as 5 . In rat plasma the $B G H / I G H$ ratio can be as high as 400:1 depending upon sampling site. Clearly there are differences in biological and immunological activities of pituitary and plasma $\mathrm{GH}$ in the rat. 
In primates, stimuli such as cold exposure, fasting, and insulin-induced hypoglycemia produce an elevation of plasma IGH. Though the physiology of $\mathrm{GH}$ secretion in primates differs from rats in this respect, the major form of circulating $\mathrm{GH}$ in humans is also $\mathrm{BGH}$. The plasma $\mathrm{BGH}$ and IGH values in resting humans are $<100$ to $780 \mathrm{ng} / \mathrm{mL}$, and $\leq 0.8 \mathrm{ng} / \mathrm{mL}$, respectively, while in GRF-treated humans the corresponding values are 667 to $5200 \mathrm{ng} / \mathrm{mL}$, and 15 to $63 \mathrm{ng} / \mathrm{mL}$. GRF treatments produce a larger percentage increase in IGH secretion, but a larger absolute amount increase in BGH secretion relative to controls. It appears, therefore, that in humans there is differential regulation of $B G H$ and IGH secretion, suggesting that the physiology of $\mathrm{GH}$ secretion in humans and rats is probably more similar than different.

Growth hormone is now considered by most researchers to be a heterogeneous family of proteins. This subject has been extensively reviewed elsewhere for human $\mathrm{GH}$, but not for rat $\mathrm{GH}$. Rat $\mathrm{GH}$ exists as monomeric $22 \mathrm{kD}$, monomeric $40 \mathrm{kD}, 45 \mathrm{kD}$ interchain disulfide dimer forms, and covalent and noncovalent oligomers of up to 100 kD. Recently, glycosylated, and phosphorylated forms have also been detected. Most researchers use antisera raised against pituitaryderived $\mathrm{GH}$ at some point in their various approaches to the study of $\mathrm{GH}$ variants, without concurrent bioassay. Variants devoid of immunoactivity would not be detected by these assays. While the biological significance of these GH variants remains unclear, it is tempting to speculate that their existence parallels the diversity of 
physiological effects of $\mathrm{GH}$ including increased transport of amino acids across the plasma membrane of many cells, increased protein synthesis, mitosis of thymocytes, proliferation of chondrocytes and osteoblasts, and early hypoglycemic and delayed anti-insulin effects such as hyperglycemia and mobilization of fatty acids from adipocytes.

The hypophysectomized rat tibial bioassay measures only the growth-promoting activity of $\mathrm{GH}$; specifically, the effects on chondrocyte proliferation. "Classical" $\mathrm{GH}$, derived from the pituitary, possesses growth promoting activity, and is used as the reference standard for the bioassay. Secretion of BGH and IGH may or may not parallel each other, as indicated. Differences between pituitary and plasma $\mathrm{BGH} / \mathrm{IGH}$ ratios must, therefore, represent either loss of immunoactivity initially present, enhancement of growth promoting activity, selective release of a $\mathrm{GH}$ form devoid of immunoactivity, or a combination of these. It is clear that the existing immunoassays alone do not adequately reflect $\mathrm{GH}$ physiology in the rat. For this reason it is important that rat $\mathrm{GH}$ be measured by both bioassay and immunoassay.

Investigations over the past 15 years have led to the separation of somatotrophs into two functionally distinct populations using bovine serum albumin (BSA) density gradient techniques. The lower density cells $(1.050-1.068 \mathrm{~g} / \mathrm{mL})$ are called type 1 somatotrophs, while the higher density cells (1.071-1.084 $\mathrm{g} / \mathrm{mL}$ ) are called type 2 somatotrophs. Type 1 cells represent 40 - 
$45 \%$ of pituitary somatotrophs, while type 2 cells represent $55-60 \%$ of pituitary somatotrophs. Somatostatin (SRIF) has been shown to decrease IGH release from both cell types, while dibutyrl cyclic AMP has been shown to increase IGH release. The effects of these agents on BGH release are unknown. Hydrocortisone and thyroxine have differential effects on the two cell types, the former increases intracellular IGH in type one cells only while the latter stimulates IGH secretion in type two cells only. These results suggest a potential heterogeneity in control of these two somatotroph types. Importantly, the type 2 cells secrete significantly more GH (2-6 times) over a 4-day culture period than do the type 1 cells. The $\mathrm{BGH} / \mathrm{IGH}$ ratio for secreted $\mathrm{GH}$ in 4-day cultures is about 5 in type 2 cells and about 0.5 in type I cells. The type 2 cells thus release more of a GH variant which is rich in bioactivity but relatively devoid of immunoactivity.

\section{Hypothesis}

In 1980 rat hypothalamic GH releasing factor (GRF) was purified to homogeneity and subsequently sequenced and synthesized by solid phase techniques. In in vitro and in vivo studies the GRF caused release of IGH with associated increases in growth. Therefore, it seems unlikely that hypothalamic release of this particular GRF (43 amino acid residues) can explain the phenomenon of selective BGH release in the stress experiments mentioned above. Yet there is evidence that GRF is released during stress in rats. 
SRIF is also released during stress in rats. It may be that in those experiments which have reported selective $B G H$ release, that the type 2 somatotroph is preferentially stimulated by a certain ratio of concentrations of hypothalamic GRF and SRIF, and that when the concentration ratio is appropriate, differential suppression of IGH release from the type 1 somatotroph occurs. This is a reasonable conclusion if the sensitivities to GRF and SRIF differ between type 1 and type 2 cells. Therefore, the purpose of this thesis is to test the hypothesis that the appropriate dose combination of GRF and SRIF stimulates release of $\mathrm{BGH}$ from type 2 somatotrophs with little or no increase in release of IGH from type 1 somatotrophs.

Alternatively, it may be that another, as yet unspecified releasing factor differentially regulates the two somatotroph populations. 


\section{MATERIALS AND METHODS}

\section{Pituitary Donors.}

Male Sprague-Dawley derived rats (Simonsen; Gilroy, CA) were used in all experiments, except where otherwise noted. Rats were typically $240-260 \mathrm{~g}$ at the time of termination. All rats were housed in groups of 5 in temperature controlled rooms $\left(24-26^{\circ} \mathrm{C}\right)$. Food (Wayne Lab-blox F-6) and water was provided ad libitum. Animal care was provided by the Animal Care Facility at NASA-Ames Research Center and all experiments were approved by the Institutional Animal Care and Use Committee, NASA-Ames Research Center. On the day of each experiment, all animals were killed by decapitation within a 1-hour period occurring between 6 and 9 AM. After opening the cranium with poultry shears (to remove the brain), the heads were transferred to an asceptic surgical field, where separate workers removed the pituitaries. The neurohypophysis was separated and discarded, and the adenohypophysis was transferred to Petri dishes containing filter-sterilized media A (see Appendix A). After pituitaries were collected from the donors, the dissociation procedures were carried out under sterile conditions within a laminar flow hood.

\section{Preparation of Adenohypophyseal Cell Suspensions.}

The procedures for cell dissociation are described by Wilfinger, et al. [114] with modifications by Snyder, et al. [99]. All 
glassware was siliconized with Sigmacote ${ }^{\mathrm{TM}}$ (Cat. no. SL-2, Sigma Chemical Co.; St. Louis, MO) to reduce cell attachment and to eliminate potential toxicity to bioassay rats subsequently injected with cell culture media (see introduction and literature review: studies with hypothalamic extracts). Within a laminar flow hood, adenohypophyses were transferred to a sterile Petri dish and cut into 1.0-1.5 $\mathrm{mm}^{3}$ blocks with a sterile razor blade. The blocks were transferred to a $25 \mathrm{~mL}$ Spinner flask (Cat. no. 1967-00025; Bellco Glass, Vineland, NJ) containing $10 \mathrm{~mL}$ of filter-sterilized trypsincontaining media B (see appendix A). Not more than 20 adenohypophyses were transferred to each Spinner flask. The flasks were stirred constantly for 45 minutes at $\approx 100$ r.p.m. on a magnetic stirrer unit, then the partially dissociated cells were transferred with media and $100 \mu \mathrm{L}$ of sterile $2 \mathrm{mg} / \mathrm{mL}$ DNase to a $15 \mathrm{~mL}$ centrifuge tube and centrifuged using a table-top centrifuge for 10 minutes at $\approx 2500 \times \mathrm{G}$. After centrifugation, the supernatant was discarded and the pellet was resuspended in filter-sterilized media $C$ (see appendix A) by triturating (slowly drawing the suspension into a Pasteur pipette and then ejecting it) 50 times with a sterile Pasteur pipette. The triturating also served to mechanically dissociate the partially dispersed cells. After triturating, any adenohypophysis pieces were allowed to settle for 2-3 minutes. The cell suspension was next collected and transferred to a sterile 15 $\mathrm{mL}$ centrifuge tube. Soybean. Trypsin Inhibitor (100 $\mu \mathrm{L}$ of $1 \mathrm{mg} / \mathrm{mL}$ soybean trypsin inhibitor [Cat. no. T-9003; Sigma Chemical Co., St. 
Louis, MO] in media A ) was added to the cell suspension to inhibit further proteolysis. The pieces were transferred back to the Spinner flask with $10 \mathrm{~mL}$ of fresh trypsin-containing media $B$ for a second 45 minute dissociation. After the second dissociation, the fresh cell suspension was obtained and processed exactly as the first suspension. The cell suspension obtained was pooled with cells from the first dissociation. After the second dissociation few, if any, pituitary pieces remained. In all cases any remaining pieces were discarded. Typical pituitary cell yield was 3 million cells per rat. Consequently, the stock cell suspension obtained after the second dissociation was diluted to a volume equivalent to $1.0 \mathrm{~mL}$ per donor rat, giving a final concentration of approximately 3 million cells per $\mathrm{mL}$ of media $\mathrm{C}$.

\section{Cell Counting, Dilutions, and Treatments.}

The stock cell suspension was triturated several times, and a small aliquot was accurately counted using a hemocytometer. Once the cell concentration in the stock cell suspension was determined, the remaining procedures were performed. For mixed pituitary cell experiments, the cells were diluted to a final cell concentration of $1.5 \times 10^{6}$ cells per $5.0 \mathrm{~mL}$ of media $\mathrm{C}$ (see appendix A). Five $\mathrm{mL}$ aliquots of the mixed cell suspension were transferred to sterile 15 $\mathrm{mL}$ centrifuge tubes. The suspension was triturated 5 times between aliquots to assure homogeneity. The tubes were then centrifuged for 10 minutes at $2500 \times$ G, and the supernatant was 
discarded. Five $\mathrm{mL}$ aliquots of fresh media $\mathrm{C}$ alone, or supplemented with various concentrations of GRF, SRIF, or both, were then added to the cell pellets. The pellets and media were triturated 20 times with a Pasteur pipette, and the suspension was quantitatively transferred to $70 \mathrm{~mL}$ culture flasks $\left(25 \mathrm{~cm}^{2}\right.$ surface area, cat. no. 25100; Corning, Palo Alto, CA). During all experiments, except where otherwise noted, flasks of cells in media were incubated with the cap of the flask turned to the position which enables gas exchange with the atmosphere. The flasks were incubated at $37^{\circ} \mathrm{C}$ in the presence of humidified $5 \% \mathrm{CO}_{2}$ and $95 \%$ air.

For the cell separation procedure, aliquots of the stock cell suspension were centrifuged for 10 minutes at $2500 \times$ G using a table top centrifuge, supernatant was discarded, and replaced with cold media $A$ to produce a final concentration of $1 \times 10^{7}$ cells per 1.5 $\mathrm{mL}$. The cells obtained were pooled and triturated 50 times to produce a homogeneous gradient cell stock suspension for the density gradient procedure.

\section{Density Gradient Cell Separation Procedure.}

The bovine serum albumin (BSA) density gradient cell separation procedure has been described in detail by Hymer [45]. The procedure of Shortman [96] was used to prepare the BSA. The BSA stock solution (see appendix A) was gradually diluted with unbalanced salt solution (UBSS; see appendix $A$ ) and the refractive index was determined using a Baush and Lomb Abbe refractometer 
(Cat. No. 33.45.71). The dilution procedure was repeated until the correct refractive index was obtained. The equation for converting refractive index to density, as described by Shortman [96], was:

$$
\text { Density }=\left(10^{4} n_{\text {sample }}-6263.2\right) / 7047.2
$$

where $n_{\text {sample }}$ is the refractive index of the sample solution, as determined by the refractometer. When solutions of the correct density were obtained, the samples were delivered to a laminar flow hood where $1.5 \mathrm{~mL}$ aliquots of the $1.085 \mathrm{~g} / \mathrm{mL}$ BSA solution were transferred to $15 \mathrm{~mL}$ sterile plastic centrifuge tubes and stored frozen $\left(-5^{\circ} \mathrm{C}\right)$. The $1.071 \mathrm{~g} / \mathrm{mL}$ BSA solution was also stored frozen $\left(-5^{\circ} \mathrm{C}\right)$. On the day before an experiment the solutions were thawed overnight under refrigeration $\left(4^{\circ} \mathrm{C}\right)$ and mixed prior to use to ensure homogeneity. All solutions were kept at $4^{\circ} \mathrm{C}$ to ensure correct density. A $1.5 \mathrm{~mL}$ aliquot of $1.071 \mathrm{~g} / \mathrm{mL}$ BSA solution was carefully layered on top of the $1.085 \mathrm{~g} / \mathrm{mL}$ layer, and a $1.5 \mathrm{~mL}$ aliquot of the gradient cell suspension was carefully layered on top of the 1.071 $\mathrm{g} / \mathrm{mL}$ layer. The entire system was carefully transferred to a $4^{\circ} \mathrm{C}$ refrigerated centrifuge, and centrifuged at $1000 \times \mathrm{G}$ for 30 minutes. The majority of cells sedimented in 3 locations within the system: at the interface between $1.071 \mathrm{~g} / \mathrm{mL}$ BSA and media $\mathrm{C}$ (type 1 cells); at the interface between $1.085 \mathrm{~g} / \mathrm{mL}$ and $1.071 \mathrm{~g} / \mathrm{mL}$ BSA (Type 2 cells); and a pellet at the bottom of the tube. In all cases the pellet was discarded. Type 1 and type 2 cells were carefully removed with a sterile Pasteur pipette in a laminar flow hood. The dense BSA solutions and cells were diluted with fresh media $A$, triturated 50 
times with a Pasteur pipette, transferred to $15 \mathrm{~mL}$ sterile plastic centrifuge tubes, centrifuged 10 minutes at $1000 \times \mathrm{G}\left(22-24^{\circ} \mathrm{C}\right)$, and the supernatant was discarded. The type 1 and type 2 cell pellets were resuspended to an approximate concentration of 3 million cells per $\mathrm{mL}$ of media $\mathrm{C}$, triturated 50 times, or until all "clumps" were separated, and counted on a hemocytometer. Once accurate cell concentrations were determined for type 1 and type 2 cell stock suspensions, the concentrations were adjusted to $3.6 \times 10^{6}$ cells per $5.0 \mathrm{~mL}$ media $C$ and $0.6 \times 10^{6}$ cells per $5.0 \mathrm{~mL}$ media $C$, respectively ${ }^{1}$. At this point the remaining procedures were identical to those mentioned for mixed cells (see above).

\section{Cell Extracts for Intracellular GH Determination.}

In many experiments both start and post-treatment extracts of cells were made to determine intracellular $\mathrm{GH}$ concentrations. For mixed cell start extracts $3.0 \times 10^{6}$ cells were typically extracted in $10.0 \mathrm{mLs}$ of alkaline solution. For type 1 and 2 cells, $7.2 \times 10^{6}$ and $1.2 \times 10^{6}$ cells, respectively, were extracted in $10.0 \mathrm{~mL}$ of alkaline solution. In the early experiments the alkaline solution used was $0.01 \mathrm{M} \mathrm{NaHCO}_{3}$, but this was later replaced with $0.01 \mathrm{M} \mathrm{Na}_{2} \mathrm{CO}_{3}$ since $\mathrm{GH}$ is more soluble in solutions of higher $\mathrm{pH}$. The cells were incubated overnight $\left(4^{\circ} \mathrm{C}\right.$ for $\left.12-18 \mathrm{~h}\right)$, followed by centrifugation

\footnotetext{
1 Choice of cell concentration was designed to keep the number of somatotrophs constant between cell types. W. Hymer has shown that when mixed somatotrophs are cultured with increasing numbers of 3T3 fibroblasts, secretion of IGH remains constant when expressed on a per somatotroph basis (unpublished).
} 
and, finally, collection of the supernatant which was kept frozen until assay.

\section{Viability Determination.}

Viability determinations were made using a neutral red dye uptake procedure. In this method viable cells actively transport neutral red into their interior, thus producing stained cells. Nonviable cells remain unstained. The viability media were prepared on the day of each experiment by mixing $0.3 \mathrm{~mL}$ of the neutral red stock solution (see appendix A) with $9.7 \mathrm{~mL}$ of media C. Aliquots of cells were incubated for 20-40 minutes in viability media at room temperature. After the incubation, differential cell counts were made on a hemocytometer. Viability estimates were typically $85 \%$ or better.

\section{Immunoperoxidase Staining of Somatotrophs}

The immunoperoxidase method for staining pituitary cells described by Denef $e t$ al. [21], was used in these studies with minor modifications. Aliquots of 50,000 cells per $100 \mu \mathrm{L}$ media $\mathrm{C}$ were placed onto $12 \mathrm{~mm}$ round polylysine-coated coverslips in multiwell culture plates (24-well plates, Linbro Cat. \#76-033-05; Flow Laboratories, McLean, VA) and allowed to incubate for 1 hour before fixation. The coverslips had been previously prepared by soaking in $95 \%$ ethanol for 10 minutes, washing with distilled water, and then spreading the coverslips into a monolayer in a Petri dish containing 
$0.01 \%$ w/v poly-L-lysine (HBr M.W. $>300$ kD, Cat. \# P-1524; Sigma Chemical Co., St. Louis MO) for 30 minutes. The coverslips were then rinsed with distilled water and transferred to the $2 \mathrm{~mL}$ wells on the Linbro' ${ }^{\mathrm{TM}}$ plates. The plates were placed into a laminar flow hood equipped with a U.V. lamp (2 Westinghouse Sterilamp 782L-30 lamps) and sterilized for 24 hours (2.5 feet from light source). The cells were fixed for 30 minutes with $0.5 \mathrm{~mL} /$ well of Zamboni's fluid (see appendix A). After the $\mathbf{3 0}$ minute fixation, the cells were washed two times quickly, followed by one 10 minute wash with 0.5 $\mathrm{mL}$ per well of phosphate buffered saline (PBS; see appendix A). At this point the cells were stored at $4^{\circ} \mathrm{C}$ for $24-48$ hours. After this period, the cells were incubated for one hour in $0.5 \mathrm{~mL}$ per well of $0.15 \%$ phenylhydrazine $\mathrm{HCl}(\mathrm{pH} 7.2$; filtered through Whatman \#1 filter paper) in PBS in order to inhibit endogenous peroxidase activity. The cells were then washed twice with $0.5 \mathrm{~mL}$ per well of PBS, and incubated at $4^{\circ} \mathrm{C}$ overnight in $0.5 \mathrm{~mL}$ per well of $1 \%$ crystalline BSA in PBS in order to decrease non-specific binding. Cells were then incubated for $36-60$ hours at $4^{\circ} \mathrm{C}$ with $0.5 \mathrm{~mL}$ per well of primary antibody. The primary antisera used in these experiments was Rhesus monkey anti-rat pituitary GH (provided by R.E. Grindeland) at a dilution of $1 / 10,000$ in $0.4 \%$ Triton $X-100$ (Sigma, St. Louis, MO) in Tris- $\mathrm{NaCl}$ buffer $(6.005 \mathrm{~g} / \mathrm{L}$ Tris, $30 \mathrm{~g} / \mathrm{L}$ $\mathrm{NaCl}, \mathrm{pH}$ 7.6). Non-immune monkey serum (obtained from Rhesus monkeys housed at the animal care facility; NASA Ames Research Center, Moffett Field, CA) at the same dilution served as a control. 
After the incubation period, the cells were washed 3 times, 10 minutes each with $0.5 \mathrm{~mL}$ per well Tris- $\mathrm{NaCl}$ buffer. The cells were then incubated in $0.5 \mathrm{~mL}$ per well secondary antibody for 60 minutes at $37^{\circ} \mathrm{C}$. The secondary antibody was goat peroxidase conjugated goat anti-monkey IgG (Cat. \#3210-0081; Cappel, Malvern, PA) at a $1 / 200$ dilution in $0.025 \%$ Triton $\mathrm{X}-100$ in Tris- $\mathrm{NaCl}$ buffer. After the secondary antibody incubation the cells were washed 3 times, 10 minutes each with $0.5 \mathrm{~mL}$ per well Tris- $\mathrm{NaCl}$ buffer, and incubated for 1 hour at $37^{\circ} \mathrm{C}$ in $0.5 \mathrm{~mL}$ per well of tertiary antibody. The tertiary antibody was goat peroxidase-conjugated antiperoxidase (gPAP Cat. \#0100-1221; Cappel, Malvern, PA) and served to amplify the staining activity when substrate was added. The cells were then washed 2 times, 10 minutes each with $0.5 \mathrm{~mL}$ per well of $0.025 \%$ Triton $\mathrm{X}-100$ in Tris- $\mathrm{NaCl}$ buffer, and then washed 2 times, 10 minutes each with $0.5 \mathrm{~mL}$ per well of Tris- $\mathrm{NaCl}$ buffer. After the final wash step, $0.5 \mathrm{~mL}$ per well of substrate was added. The substrate solution was prepared by mixing $10 \mathrm{mg}$ of $3,3^{\prime}-$ diaminobenzidine-tetrachloride (Cat no. D-5637; Sigma Chemical

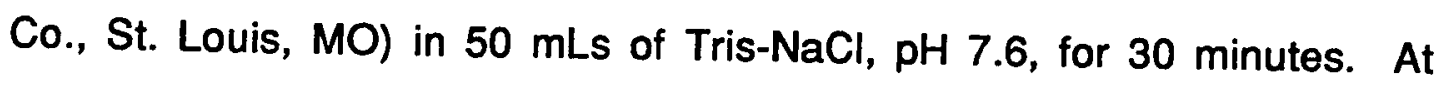
the end of the 30 minutes of mixing, $100 \mu \mathrm{L}$ of $3 \% \mathrm{H}_{2} \mathrm{O}_{2}$ was added and the substrate was delivered to the wells. The system was incubated at $37^{\circ} \mathrm{C}$ for $30-45$ minutes, until the desired degree of staining was obtained. Once the cells were adequately stained, they were washed 3 times with distilled water and mounted onto glass microscope slides with $60^{\circ} \mathrm{C}$ Kaiser's glycerol (see appendix A) for 
differential cell counting. The differential cell counting enabled GH secretion to be expressed on a per somatotrophs-seeded basis rather than a per cells-seeded basis. For each determination, at least 1000 cells were counted. In all cases the normal-monkey serum controls were unstained.

\section{Radioimmunoassay of $\mathbf{G H}$}

The procedure for the radioimmunoassay of rat $\mathrm{GH}$ and its specificity has been described by Schalch and Reichlin [89]. The assay is a homologous double antibody RIA. The assay used in these experiments differed from that of Schalch and Reichlin in that the primary antibody $(1 / 50,000$ in BSA-phosphate buffer $\mathrm{pH} 7.5)$ was raised against highly purified rat pituitary granule-derived $\mathrm{GH}$ in rhesus monkeys ${ }^{1}$. The primary antisera was freed of complement proteins by incubating at $56^{\circ} \mathrm{C}$ for 30 minutes. The precipitating second antibody was goat anti-monkey (Antibodies, Inc.; Davis, CA) at a 1/25 dilution. Normal monkey serum (obtained from Rhesus monkeys housed at the animal care facility at NASA Ames Research Center, Moffett Field, CA) at a 1/20 dilution in BSA-phosphate buffer $\mathrm{pH} 7.5$ was used as a carrier to increase the mass of precipitate. Tracer $\mathrm{GH}$ was radiolabeled (125I) by the chloramine T/metabisulfite method [42]. Radioactive counts per minute were quantitated using a Multi-Pras ${ }^{\mathrm{TM}} 4$ gamma counter (Packard). The

\footnotetext{
${ }^{1}$ The antiserum was raised against $r G H$ with 3 U.S.P. units per milligram (preparation XVII-38-38C); supplied by R.E. Grindeland. The U.S.P. unit is defined in the footnote on
p.45.
} 
assay has a range of linearity (when the logit transformation is performed) from 1.6 to $50.0 \mathrm{ng} / \mathrm{mL}$, with an $\mathrm{ED}_{50}$ of $10 \mathrm{ng} / \mathrm{mL}$. Interassay coefficient of variation, was $11 \%$ for experiments $A-G$, and $<6 \%$ for experiments $\mathrm{H}-\mathrm{J}$. The differences were most likely due to use of positive displacement pipettes in the latter assays, whereas positive displacement pipettes were not used in the earlier assays.

\section{Bioassay of $\mathbf{G H}$}

The tibial bioassay using hypophysectomized rats was followed unmodified according to the procedures of Greenspan, et al. [33]. Twenty-six day old hypophysectomized rats were purchased from either Zivic-Miller (Zelienople, PA), Simonsen Laboratories (Gilroy, CA), or Charles River Laboratories (Portage, MI). The dose-response was statistically identical in rats from all suppliers, as was the epiphyseal width for saline-injected rats. In all assays, sample injections began 2 weeks poșt-hypophysectomy. The 2-week interval allowed for surgical recovery and allowed time to determine whether hypophysectomy was complete. Typically, if the rat weight was greater than $90 \mathrm{~g}$, or the weight change over the 2-week period was greater than $15 \mathrm{~g}$, the rat was not considered to be hypophysectomized and was not used in the assay. The injections occurred over a period of 4 days, with one $0.5 \mathrm{~mL}$ i.p. injection of sample or standard per rat per day. Bovine GH standards (XIV-44C5, 
1.5 U.S.P. units per $\mathrm{mg}^{1}$, supplied by R.E. Grindeland) were $45 \mu \mathrm{g}, 15$ $\mu \mathrm{g}$, and $5 \mu \mathrm{g}$ total injected over the 4-day period. On the fifth day, rats were terminated by $\mathrm{CO}_{2}$ asphyxiation, and a single tibia was removed, placed on a wooden block with the dorsal surface down, and longitudinally sectioned with a razor blade to expose the proximal epiphysis. In cases where the right tibial epiphysis broke during sectioning, the left tibia was substituted. The tibias were then rinsed in $0.5 \mathrm{~L}$ of $0.85 \% \mathrm{w} / \mathrm{v}$ saline for 30 minutes, followed by distilled water $(0.5 \mathrm{~L})$ for 20 minutes to remove chloride ions. The tibias were then defatted in $100 \%$ acetone $(0.5 \mathrm{~L})$ for 10 minutes, rinsed again with distilled water for 10 minutes, and finally stained by immersion in $100 \mathrm{~mL}$ of $2.5 \% \mathrm{w} / \mathrm{v} \mathrm{AgNO}_{3}$ for 2.5 minutes, and briefly (30 sec.) rinsed in distilled water. The tibias were then placed in Petri dishes containing distilled water, and the cut surfaces were exposed to sunlight for 1-3 minutes to initiate the photostaining reaction. The sunlight exposure occurred at about 4 p.m. on the day of termination of bioassay rats. The duration of exposure depended upon the extent of darkening which had occurred prior to that step in the procedures. This silver staining method stains primarily mineralized collagen. The newly produced (i.e. nonmineralized) cartilage of the epiphysis remains white. Optimal photostaining is somewhat subjective depending on the microscopist,

\footnotetext{
1One U.S.P. Unit equals the amount of $\mathrm{GH}$ which, when injected over a 10-day period, produces a $30-35 \mathrm{~g}$ weight change in a $100 \mathrm{~g}$ male rat which has been hypophysectomized
for 2 weeks.
} 
but should yield maximal contrast between mineralized and nonmineralized collagen, thereby favoring consistency of measurement. After staining was completed, the tibias were then placed in vials containing $70 \%$ ethanol until measurements of the epiphyseal plate could be made via ocular micrometry. Ten equidistant measurements of a single growth plate were averaged to give a single value for each bioassay rat. The log of the total 4-day dose was plotted against the epiphyseal width to give a linear standard curve. In all values reported, readings of epiphyseal width were performed by Dr. R.E. Grindeland. Dr. Grindeland has had over 20 years experience with the assay and a single evaluator resulted in low assay variability. Pituitary-derived rat $\mathrm{GH}$ has a potency which is exactly twice that of the bovine standards [35]. This factor was used in the tibial assay to convert the bovine $\mathrm{GH}$ value into rat $\mathrm{GH}$ equivalents. In many cases, both high and low doses of sample were assayed so that the linearity of the dilution curve could be statistically compared to that of the standards with a multiple regression statistical computer program based on the method of Bliss [10].

\section{Statistical analyses}

The design of individual experiments was limited by three factors. Due to the approximately 1000-times lower sensitivity of the tibial bioassay as compared to the RIA, 1000-times more GH was required for assay than would be required in experiments using RIA alone. Secondly, the cell separation procedure required very large 
numbers of cells (see Methods section; Density Gradient Cell Separation Procedure). Thirdly, due to the large number of cells required for each experiment and the number of experimental variables, the number of procedural operations per experiment was usually at the maximum possible. The aforementioned factors made it impossible to obtain a large enough sample size for valid analysis of variance (see individual experiments below). Statistical comparisons of triplicate data point determinations would not be valid in experiments in which cells were derived from a commen donor pool. For the reasons above, comparisons between treatment groups were normalized and expressed as percent-differences. The most important experiments were replicated to demonstrate the reliability of results (see individual experiments below).

\section{Experiment A: Mixed Cell BGH and IGH Secretion in Response to hpGRF-40}

The purpose of this experiment was to examine the effects of human pancreatic tumor-derived hpGRF-40 (from a human tumor extract) on $\mathrm{BGH}$ and IGH release in 4-day-old monolayer cultures of mixed pituitary cells. This experiment represented the first investigation of the effects of hpGRF-40 on BGH secretion. It was not expected that differential secretion of $\mathrm{BGH}$ could be explained on the basis of GRF alone (as previously described), but this possibilility needed to be ruled out before proceeding with further experiments. 
To determine the dose response to hpGRF-40, pituitaries were obtained from 8 male Simonsen rats, $242-260 \mathrm{~g}$. Dissociated cells were plated at a concentration of 150,000 cells per $\mathrm{mL}$ per well in 24-well plates (Linbro Cat. \#76-033-05, Flow Laboratories, McLean, VA) and pre-cultured at $37^{\circ} \mathrm{C}$ in humidified air with $5 \% \mathrm{CO}_{2}$ for 4 days prior to treatment with GRF. One $3 \times 10^{6}$ cell aliquot of "start" cells was extracted with $0.01 \mathrm{~N} \mathrm{NaHCO}_{3}$ as previously described. Choice of the 4-day preculture period was based both on the frequent use of this procedure in the literature $[17,40,100]$. Choice of the 4-hour treatment period was based on the demonstration by Bilezikjian and Vale [9] that, when sampled at 15, 30, 60, 120 and 240 minutes, basal and $1 \mathrm{nM}$ hpGRF-stimulated IGH secretion is linear with 3 , and 17 times increases in media IGH concentration, respectively, over this 4 hour period (relative to control secretion at 15 minutes). After the 4 day preculture, alpha MEM culture media were collected, and replaced with fresh media for a one hour incubation. After the one hour incubation, 4-hour treatments with culture media containing various concentrations of GRF began. The GRF concentrations were $0,0.39$, $1.56,6.25,25.0,100$, or $400 \mathrm{nM}$ hpGRF-40 (note each successive dose was 4 times the previous dose). There were 20 culture wells per treatment dose. At the end of the 4-hour treatment, media were collected and 24-hour extracts with $0.01 \mathrm{~N} \mathrm{NaHCO}_{3}$ were made as previously described. Viability determinations were made postdissociation and at the end of the 4-hour treatment period, as already described. Two groups of 10 wells per treatment dose were pooled, 
and $100 \mu \mathrm{L}$ samples were used for duplicate RIA determinations for both media and extracts. The two groups of 10 wells per treatment dose were pooled for bioassay. The hypophysectomized bioassay rats were supplied by Zivic-Miller (Zelienople, PA). One sample point (5 rats) was read against a standard curve generated from 3 dose levels (5 rats per point); 45,15 , and $5 \mu \mathrm{g}$, as already described.

\section{Experiment B: Determination of Preculture Optimal Duration}

As mentioned above, most researchers preculture cells for 3-5 days prior to treatment with GRF or other test secretagogues. To the best of the writer's knowledge, in no case has experimental validation of this procedure been reported. It should be noted that the handling of cells is easier after attachment to substrate, which occurs following preculture. The purpose of this experiment was to examine the effect of duration of preculture on basal and GRFstimulated $\mathrm{GH}$ secretion.

Fifteen male Simonsen rats, $208-247 \mathrm{~g}$, were used as pituitary donors for separate, duplicate experiments which were run simultaneously. Seven and 1/2 pituitaries per experiment were dissociated to single cell suspensions, precultured for $0,1,2$, or 4 days, and then treated for 4 hours with media $C$ containing 0,5 , or 20 nM hpGRF44 (supplied to R.E. Grindeland by Jean Rivier, Salk Institute, La Jolla, CA). Cells were cultured in $70 \mathrm{~mL}$ flasks $\left(25 \mathrm{~cm}^{2}\right.$ surface area, Cat. no. 25100; Corning, Palo Alto, CA) at a concentration of 1.5 $X 10^{6}$ cells per $5.0 \mathrm{~mL}$ per flask. The cells were incubated at $37^{\circ} \mathrm{C}$ 
with closed caps (no gas exchange). There was one flask per treatment condition per experiment. Post-dissociation and posttreatment viability determinations were made, with the exception of the time-zero post-treatment groups. Treatment media were collected as previously described. For all treatment groups GH was measured by RIA and by tibial assay. For simplicity, the duplicate experiments will be called experiment $B 1$ and $B 2$, respectively. Experiment B1 hypophysectomized bioassay rats were supplied by Charles River Labs, while experiment B2 hypophysectomized bioassay rats were supplied by Zivic Miller Labs. In the experiment B1 bioassay, one sample point (5 rats) was read against a standard curve generated from 3 dose levels (5 rats per point); 45,15 , and $5 \mu \mathrm{g}$, as described above. In the experiment $\mathrm{B} 2$ bioassay, one sample point ( 3 rats) was read against a standard curve generated from 2 dose levels (5 rats per point); 45 , and 15 , as described above.

\section{Experiment C: Effects of Culture Conditions on Basal and hpGRF-Stimulated IGH Secretion}

In experiment B, cells were incubated in $70 \mathrm{~mL}$ culture flasks with closed caps, thus preveriting gas exchange with the external environment. Not only does this reduce the amount of $\mathrm{O}_{2}$ available to cells, but $\mathrm{CO}_{2}$ exchange is also reduced. Both of these conditions could conceivably affect hormone production and release, thus complicating the interpretation of experiment $B$ results. For this reason, in this experiment the effects of a closed culture flask filled 
with air only (C/A) were compared with closed flasks filled with $5 \%$ $\mathrm{CO}_{2} / 95 \%$ air $(\mathrm{C} / \mathrm{C})$, and "open" flasks constantly exposed to humidified $5 \% \mathrm{CO}_{2} / 95 \%$ air $(\mathrm{O} / \mathrm{C})$. "Open" flasks simply have the cap loosely fitted so that gas exchange can occur.

Eight male Taconic Farms rats, $329-420 \mathrm{~g}$, served as pituitary donors in this experiment. Cells were precultured in $70 \mathrm{~mL}$ culture flasks for durations of 2 or 4 days, media were collected, and cells were then incubated for a 4-hour GRF-treatment period. On each treatment day, 2 flasks per culture condition were exposed to media C containing $5 \mathrm{nM}$ hpGRF-40. Preculture and treatment media from duplicate flasks were collected and assayed by RIA. Start and posttreatment viability determinations were made for all groups as described earlier.

\section{Experiment D: Determination of $\mathbf{G H}$ Stability in Culture Media}

To the best of the writer's knowledge, there are no reports within the published literature which address the problem of degradation of IGH over time, as it sits in culture media at $37^{\circ} \mathrm{C}$ in the presence of adenohypophyseal cells. This experiment examined the stability of human pituitary-derived GH (hGH; 3 U.S.P. units per mg; Kabi, Stockholm, Sweden) over a 4-day culture period.

Eight male Taconic Farms rats, $329-420 \mathrm{~g}$, served as pituitary donors in this experiment. The mixed, dissociated cells were incubated in multiwell culture plates (24-well plates, Linbro Cat. 
\#76-033-05, Flow Laboratories, McLean, VA) at a concentration of $1.5 \times 10^{5}$ cells per $1.0 \mathrm{~mL}$ culture media per well. Twenty-four wells containing media $\mathrm{C}$ spiked with $5 \mu \mathrm{g}$ hGH per $\mathrm{mL}$, and 24 wells containing media $\mathrm{C}$ only, were incubated in the presence of cells at $37^{\circ} \mathrm{C}$ in $5 \% \mathrm{CO}_{2}$ and $95 \%$ humidified air. Six wells each were collected on days $1,2,3$, and 4 . Similarly, aliquots of the same hGHspiked media $C$ were incubated without cells and collected at the same times. At time zero, aliquots of media were exposed to cells and then collected for subsequent assay. An aliquot of fresh hGHspiked media were also saved for assay. Since the rabbit anti-hGH antiserum (Grindeland) does not cross-react with rat $\mathrm{GH}$, and the monkey anti-rat $\mathrm{GH}$ antiserum does not cross-react with $\mathrm{hGH}$, media were independently radioimmunoassayed for $h \mathrm{GH}$ and rat $\mathrm{GH}$. The hGH results provided estimation of $\mathrm{GH}$ degradation over time. When compared with alpha MEM media controls, the rat IGH results for hGHspiked media provided an estimate of feedback inhibition of rat $\mathrm{GH}$ secretion.

\section{Experiment E: Validation of Cell Separation Procedure -} Single Phase Method

Initially, it was planned that somatotrophs would be separated using a single $1.071 \mathrm{~g} / \mathrm{mL}$ layer of BSA, rather than the 2-density system already described. This method was preferred over the 2density system in light of the increased simplicity and reduced processing steps. This experiment was thus performed to replicate 
the earlier work of Hymer (see Introduction), and to gain experience with the cell separation procedure.

In this method $1.5 \mathrm{~mL}$ of cells $\left(10 \times 10^{6}\right.$ cells) plus media are layered on top of $1.5 \mathrm{~mL}$ of sterile $1.071 \mathrm{~g} / \mathrm{mL}$ BSA in a plastic centrifuge tube. With the exception of this difference, procedures are identical to those already described (see Density Gradient Cell Separation Procedure). After centrifugation, the type one cells form a layer at the interface between the media and BSA layer, while the type two cells form a pellet at the bottom of the centrifuge tube. In this experiment the aforementioned method was employed to separate mixed cells into type one and type two cell populations. Mixed, type one, and type two cells were cultured for 12 days in $70 \mathrm{~mL}$ culture flasks at concentrations of $1.5,3.6$, and 0.6 million cells per $5.0 \mathrm{~mL}$ of alpha MEM culture media per flask. Media were collected at days 4 , 8 , and 12 and replaced with fresh culture media on days 4 and 8.

Ten male Simonsen rats (mean $=248.3 \mathrm{~g}, \mathrm{~S} . \mathrm{D} .=8.4 \mathrm{~g}$ ) served as pituitary donors. Ten adenohypophyses were pooled and independently dissociated, separated via density gradient procedure, and cultured. Immunocytochemistry and viability procedures were performed as previously described. Mixed and type one cell treatments were performed in duplicate, while single type two treatments were performed. The cells were incubated in closed flasks filled with air only. Four, eight and 12-day media samples were radioimmunoassayed for IGH and bioassayed for BGH. The hypophysectomized bioassay rats were supplied by Charles River 
Labs. Pooled media samples were assayed at a single dose level (4 rats per point) and read against a standard curve generated from 3 dose levels, as described earlier (5 rats per point).

\section{Experiment F: Validation of Cell Separation Procedure - 2- Phase Method}

While the single phase method of cell separation apparently yields similar results as the 2-phase method in 12-day monolayer cultures, the latter method was recommended for subsequent experiments since many more experiments have been done with this method than the former (W. Hymer, personal communication, 1987). This experiment was thus performed to replicate the results of Hymer (see Introduction) and gain experience with the two-density method before proceeding with more elaborate experiments.

In this experiment, 21 male Simonsen rats $(227-250 \mathrm{~g})$ served as pituitary donors. In a single experiment, adenophypophyses were dissociated into single cell suspensions and separated via the 2phase BSA density gradient procedure already described. Immunocytochemistry and viability procedures were performed as previously described. Mixed, type one, and type two cells were cultured as in experiment $E$, with the exception that all culture flasks were "open" to $5 \% \mathrm{CO}_{2} / 95 \%$ humidified air. Mixed cell treatments were performed in triplicate, while type one and type two cell treatments were performed in quadruplicate. Four, 8, and 12-day media samples were radioimmunoassayed and bioassayed for IGH and 
$B G H$, respectively. The hypophysectomized bioassay rats were supplied by Zivic-Miller Labs (Zelienople, PA). Pooled media samples were assayed at a single dose level (4 rats per point) and read against a standard curve generated from 2 doses, as described earlier (5 rats per dose).

\section{Experiment G: Type One and Type Two Somatotroph Response to rGRF-43}

The purpose of this experiment was to generate dose-response curves in mixed, type one, and type two cells using rat GRF-43 (rGRF43; \#138-41-15 supplied by Jean Rivier, Salk Institute) in order to assess whether there are differences in responsiveness to GRF in terms of IGH and BGH secretion.

The pituitary donors were Simonsen male rats $(n=121$, mean body weight $=245.3 \mathrm{~g}$, S.D. $=8.4 \mathrm{~g}$ ). Pituitaries were removed and dissociated as previously described. The 2-phase density gradient centrifugation procedure was used. Mixed, type one, and type two cells were cultured as described in experiment $F$, with the exception that treatments with media containing various concentrations of GRF began immediately after delivery of cell aliquots to culture flasks. The treatment rGRF-43 concentrations were $0,0.39,0.78,1.56,3.13$, $6.25,12.5,25.0,100$, and $400 \mathrm{nM}$. The treatment duration was 4 hours. Immunocytochemistry and viability procedures were performed as described above. Mixed and type one cell treatments were performed in duplicate, while single type two cell treatments 
were performed. All media samples were radioimmunoassayed for $\mathrm{GH}$. Selective samples were bioassayed. The hypophysectomized rats for the bioassay were supplied by Zivic-Miller Labs (Zelienople, PA). Pooled media samples were assayed at a single dose level (4 rats per point) and read against a standard curve generated from 3 dose levels, as described earlier ( 5 rats per dose).

\section{Experiment H: Effects of BSA Incubation on Cell Viability and GH Secretion}

Because of the consistently low viability for type two cells in experiments $E, F$, and $G$, it was thought that perhaps the exposure to BSA during the density gradient procedure was preferentially toxic to type two cells or in some way affected viability. This experiment examined the effect of incubation in BSA media on cell viability and both basal and GRF-stimulated GH secretion.

Twenty male Simonsen rats (mean body weight $=269.6 \mathrm{~g}$, S.D. $=8.13 \mathrm{~g}$ ) served as pituitary donors. Pituitaries were removed and dissociated into single cell suspensions as previously described. Dissociated cells in media $A$ were either kept at room temperature $\left(22-24^{\circ} \mathrm{C}\right)$, or exposed to $4^{\circ} \mathrm{C}$, while a third group of cells were incubated in $1.078 \mathrm{~g} / \mathrm{mL}$ BSA at $4^{\circ} \mathrm{C}$ for 45 minutes per group. Choice of $1.078 \mathrm{~g} / \mathrm{mL}$ BSA was based on the fact that, in the two-phase gradient system, type two cells are exposed to both 1.071 and 1.085 $\mathrm{g} / \mathrm{mL}$ BSA. Viability determinations were made immediately postdissociation and after the 45-minute incubation. After the 45 minute 
incubations, media and cells were centrifuged at $1000 \times \mathrm{G}$ for 10 minutes in a table top centrifuge, media were discarded and replaced with alpha MEM culture media. The cells were diluted to a concentration of $1.5 \times 10^{6}$ cells per $5.0 \mathrm{~mL}$, and $5.0 \mathrm{~mL}$ aliquots were delivered to $15 \mathrm{~mL}$ plastic centrifuge tubes. After centrifugation the media were discarded, and replaced with fresh alpha MEM culture media containing $0,0.5$, or $1.5 \mathrm{nM}$ hGRF-40 (10235-15, supplied by Jean Rivier, Salk Institute). Media plus cells (in the centrifuge tube) were triturated 20 times with a Pasteur pipette, and delivered to 70 $\mathrm{mL}$ plastic culture flasks as in previous experiments. The treatment duration for all 3 groups was 4 hours. At the end of the treatment period, media were collected for subsequent radioimmunoassay and bioassay. The hypophysectomized bioassay rats were provided by Simonsen Labs. For $0 \mathrm{nM}$ GRF controls, media from duplicate flasks were combined and assayed. Whereas for $0.5 \mathrm{nM}$ GRF-treated groups, media from single flasks were assayed. These differences were required to ensure that the resultant tibial width would fall within the range of the standard curve. The $1.5 \mathrm{nM}$ GRF-treated groups and the groups which were cold-exposed only, were not bioassayed. All samples were assayed at a single dose level and read against a standard curve generated from 3 dose levels, as described earlier (5 rats per point).

The experiment was replicated at a later date using identical conditions with one exception; a 0.17 nM hGRF-40 dose level was included so that a more complete dose-response curve would be 
obtained. In the repeat experiment pituitary donors were also Simonsen males (mean body weight $=237.5 \mathrm{~g}$, S.D. $=8.7 \mathrm{~g}$ ). For simplicity, the first experiment will be referred to as experiment $\mathrm{H} 1$, and the second will be referred to as experiment $\mathrm{H} 2$. Only the 0.17 and $0.5 \mathrm{nM}$ samples for experiment $\mathrm{H} 2$ were bioassayed. The groups which were cold-exposed only were not bioassayed. Both experiment $H 1$ and $H 2$ samples were assayed in the same bioassay.

\section{Experiment I: Type One and Type Two Somatotroph Response to RGRF-43 and SRIF}

The results of experiment $G$ did not demonstrate consistent differences between somatotroph responsiveness to rGRF-43, which could explain the phenomenon of selective release of $\mathrm{BGH}$ in vivo. One might interpret this as evidence of a second GRF which either differentially affected the two cell types, or preferentially stimulated BGH release from both cell types. While this is possible, it seemed plausible to explain the phenomenon of selective BGH release in terms of known hypothalamic regulatory peptides. The most probable candidates would be GRF and SRIF, since they are specific to the GH system. Therefore, the purpose of this experiment was to test the hypothesis that various dose combinations of GRF and SRIF could stimulate release of BGH from type 2 somatotrophs with relatively little increase in release of IGH from type 1 somatotrophs.

Eighty male rats (Simonsen Labs, mean $=236.8 \mathrm{~g}, S . D .=8.56 \mathrm{~g}$ ) served as pituitary donors in this experiment. Pituitaries were 
removed, dissociated and separated via 2-phase density gradient procedures, as described above. Viability and immunocytochemistry procedures were performed as previously described. Freshly dissociated mixed, and freshly separated type one and type two somatotrophs were each subjected to 7 different 4-hour treatment conditions: $0 \mathrm{nM}$ GRF and $0 \mathrm{nM}$ SRIF (0/0), $0.25 \mathrm{nM}$ GRF and 0 SRIF (0.25/0), $1.0 \mathrm{nM}$ GRF and $0 \mathrm{nM}$ SRIF (1.0/0), $0 \mathrm{nM}$ GRF and $0.5 \mathrm{nM}$ SRIF (0/0.5), $0 \mathrm{nM}$ GRF and $10 \mathrm{nM}$ SRIF (0/10), 1.0 nM GRF and $0.5 \mathrm{nM}$ SRIF (1.0/0.5), and finally $1.0 \mathrm{nM}$ GRF and $10 \mathrm{nM}$ SRIF (1.0/10). In all cases the culture media were alpha MEM, as previously described. Choice of rGRF-43 (lot \#138-41-15, supplied by Jean Rivier, Salk Institute) doses were based on the dose-response curves for experiments $G, H 1$, and $\mathrm{H}_{2}$. In those experiments these doses gave approximately 33 and $66 \%$ of maximal GRF-stimulated secretion for both BGH and IGH. Choice of SRIF (Cat. \#S-0885; Sigma Chemical Corp., St. Louis, MO) doses were based on the work of Bilezikjian and Vale [9]. In their work, $1.0 \mathrm{nM}$ hpGRF-40-stimulated IGH release in monolayer cultures of mixed rat somatotrophs was suppressed 50 and 100 percent (to control levels), respectively, with the SRIF doses listed above. Since the culture procedures employed by these researchers are similar to those of this work, the choice of SRIF dose level seemed reasonable. The culture conditions were as described for experiment G. Mixed and type one cell treatments were performed in triplicate. Type two cell treatments were performed in duplicate. At the end of the 4-hour incubation, media were collected and cells were extracted with 0.01 
$\mathrm{N} \mathrm{Na} \mathrm{CO}_{3}$, as previously described. All media and cell extracts were radioimmunoassayed as previously described. Pooled media were bioassayed for $\mathrm{BGH}$. The hypophysectomized rats for bioassay were provided by Simonsen Labs (Gilroy, CA). All samples were assayed at two dose levels (4 rats per dose). The standard curve was generated from 3 dose levels, as described earlier ( 5 rats per dose). The unknowns were statistically compared to the standards in a 4-point multiple regression analysis using a computer program based on the procedure of Bliss ([10]; see Bioassay section in Methods).

\section{Experiment J: Type One and Type Two Somatotroph Response to RGRF-43 and SRIF}

This experiment was a replication of experiment $I$ in all respects with the exception that 100 rats served as pituitary donors (mean body weight $=236.8 \mathrm{~g}$, S.D.=2.86 g; only 10 rat weights measured). The increased number of rats provided enough cells so that triplicate type two cell treatments could also be performed. 


\section{Results}

\section{Experiment A: Mixed Cell BGH and IGH Secretion in}

Response to hpGRF-40

Post-dissociation and post-treatment cell viabilities were $96 \%$ and $81 \%$, respectively. The results for $B G H$ and IGH secretion are shown in Figure 1, panels $A$ and $B$, respectively. A plot of the $\mathrm{BGH} / \mathrm{IGH}$ (ng / 1000 cells) ratio for secreted hormone is shown in panel $C$ of Figure 1. Numeric values for each treatment in Figure 1 are indicated above each bar (panels A-C). Line graphs of the BGH and IGH dose response data (not shown) were used to calculate the ED50 dose (dose producing 50\% of the maximum response). The approximate hpGRF-40 ED50s for BGH and IGH secretion were $6.5 \mathrm{nM}$ and $0.25 \mathrm{nM}$, respectively. While GRF-stimulated IGH secretion was maximal at $1.56 \mathrm{nM}$ (Figure 1B), GRF-stimulated BGH secretion had not yet reached a maximum at $400 \mathrm{nM}$ (Figure 1A). The progressively increasing $B G H / 1 G H$ ratios (Figure $1 C$ ) reflect this phenomenon. The ED50 of $6.5 \mathrm{nM}$ for BGH secretion was approximately 65-times lower than the $400 \mathrm{nM}$ dose, which may or may not represent the dose which produces maximum secretion, since no higher dose was utilized. Consequently, the BGH dose-response curve was biphasic with one linear region in the GRF dose range of 0-6.25 $\mathrm{nM}$, and a second linear region in the GRF dose range of 25-400 $\mathrm{nM}$. The linear regression equation for the low GRF dose range was: Secretion $(\mathrm{ng} / \mathrm{mL})=15.61 \times$ Dose $+4.70(\mathrm{r}=0.943)$. The linear regression equation for the high GRF dose range was: Secretion $(\mathrm{ng} / \mathrm{mL})=52.8$ 

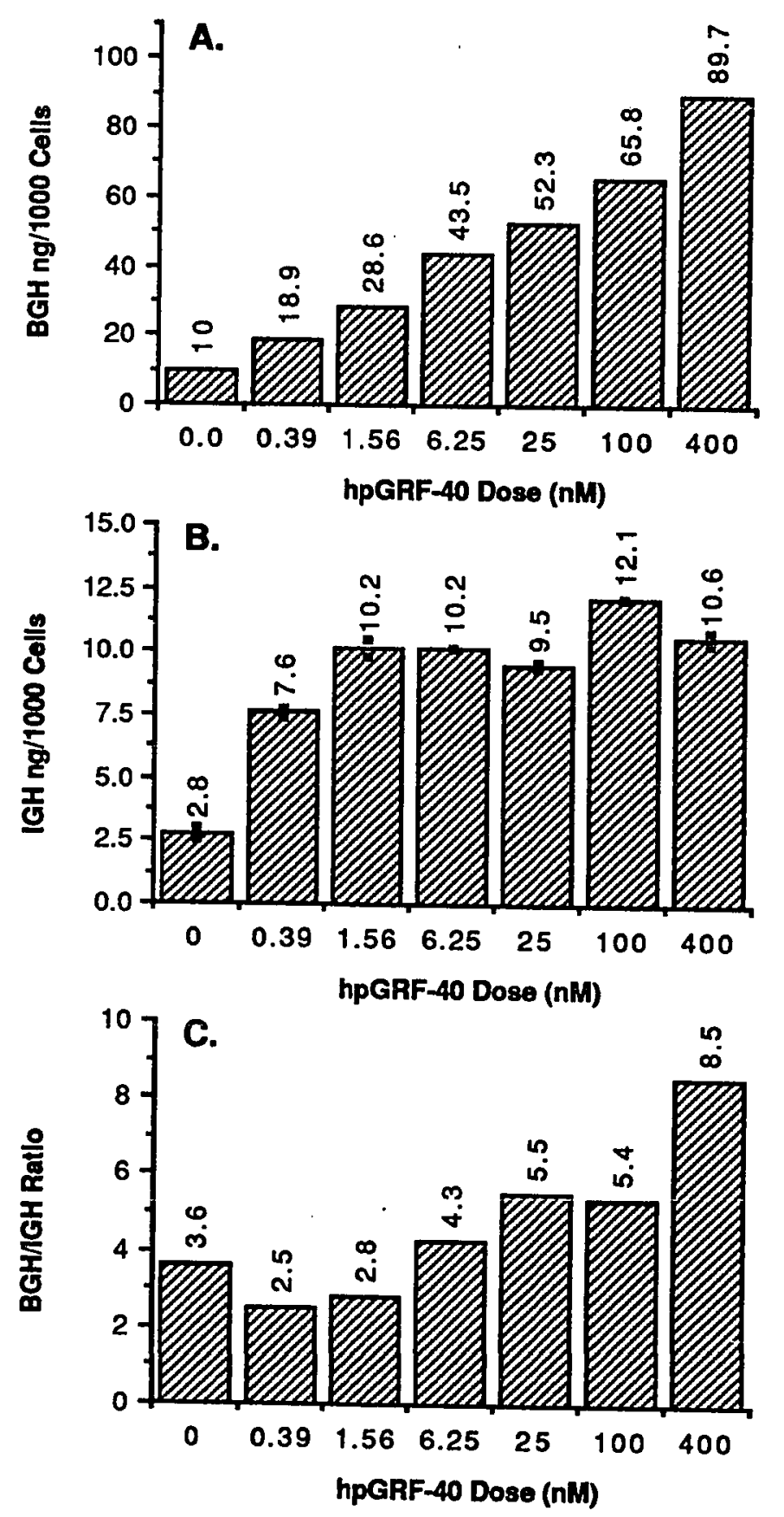

Figure 1. The effect of hpGRF-40 on BGH release (panel A), on IGH release (panel $B$ ), and on the BGH/IGH ratio for secreted GH (ratio of values in panel $A$ and $B$; panel C). Panel B data points for duplicate determinations are shown above each bar. Numeric values shown above each bar correspond to the value for that bar (calculated value for panels $A$ and $C$; arithmetic mean for duplicate determinations in panel B). 
$X$ Dose $+0.094(r=0.985)$. Net hormone production during the total culture period (preculture + 4-hour treatment) was calculated by subtracting the IGH nanogram per 1000 cells for start extracts from the sum of secreted hormone during the 4day preculture period, the 4 hour treatment period, and the post-treatment extracts. The IGH content (ng / 1000 cells) for the start extract was 6.48 (a single determination). The 4-day preculture IGH secretion was 9.57 (a single determination). The results of the calculations are shown in Table 2. Each value, with the exception of the start extract and the 4-day media, are the result of duplicate determinations. GRFinduced IGH production was calculated by subtracting the $\mathrm{GH}$ production for zero controls from hormone production for GRFtreated groups. Those results are also shown in Table 2. It can be seen in the table that the post-treatment intracellular IGH concentration was greatest in the zero GRF media controls, but with increasing GRF-doses the intracellular IGH concentration rapidly decreased and stabilized at the $1.56 \mathrm{nM}$ GRF dose. The net IGH production during the total culture period also increased withincreasing GRF dose, and plateaued at about $1.56 \mathrm{nM}$. At this dose, IGH production was 1.7-times greater than in controls (Table 2; 9.32 vs. $16.13 \mathrm{ng} / 1000$ cells). At the $1.56 \mathrm{nM}$ GRF dose, GRF-induced IGH production was $6.81 \mathrm{ng} / 1000$ cells. This value is slightly greater than 


\section{TABLE 2.}

\section{The Effect of 4-Hour GRF-Treatment on IGH Production in Mixed Cells}

(all values are expressed in $\mathrm{ng}$ per 1000 cells seeded)

$\begin{array}{ccccc}\text { GRE Dose (nM) } & \text { Secreted IGH } & \text { Post-Treatment_GH } & \begin{array}{c}\text { Net/GH } \\ \text { Production* }\end{array} & \begin{array}{c}\text { GRF-Induced IGH } \\ \text { Production* }\end{array} \\ 0 & 2.75 & 3.48 & 9.32 & 0 \\ 1.56 & 7.55 & 3.26 & 13.9 & 4.58 \\ 6.25 & 10.19 & 2.85 & 16.13 & 6.81 \\ 25 & 10.15 & 2.65 & 15.89 & 6.57 \\ 100 & 9.51 & 2.86 & 15.46 & 6.14 \\ 400 & 12.13 & 2.39 & 17.61 & 8.29 \\ & 10.55 & 2.47 & 16.11 & 6.79\end{array}$

* Note: Net IGH production = (total secreted IGH + post-culture intracellular IGH) - (initial intracellular IGH); GRF-induced IGH production $=($ Net IGH production $)-($ Net IGH production for the 0 rM GRF dose).

the amount of intracellular IGH at the start of the culture $(6.48 \mathrm{ng} /$ 1000 cells).

\section{Experiment B: Determination of Preculture Optimal Duration}

Post-dissociation and post-treatment cell viability was 88 to $92 \%$ for all groups in both experiments. The BGH and IGH secretion for experiment B1 is shown in Figure 2. Growth hormone secretion 
for the 4 different durations of preculture is plotted in groups according to GRF dose during the 4-hour treatment period. The results for BGH secretion (panel A, Figure 2) do not reveal any definite pattern with respect to duration of preculture, though it does appear that there is a trend toward decreased BGH secretion with increasing durations of preculture. This is most evident in the $20 \mathrm{nM}$ GRF-treated groups, though it should be noted that the value of $547 \mathrm{ng} / 1000$ cells for the 1-day preculture group seemed anomalous. It is not clear why the value was so high, but it could be related to some illness in the bioassay rats. 1 There was a doserelated increase in BGH secretion, with the exception of the 1 and 4day preculture groups for the $5 \mathrm{nM}$ GRF dose. The results for IGH secretion (panel B, Figure 2) indicated that there is a temporallyrelated decrease in basal and GRF-stimulated IGH secretion. Secretion of IGH for the 4-day preculture group, expressed as a percent of the 0-day preculture group, was $51 \%, 45 \%$, and $31 \%$ for 0 , 5 , and $20 \mathrm{nM}$ GRF treatments, respectively. With the exception of the $0 \mathrm{nM}$ GRF treatments, IGH secretion for the 2 and 4-day preculture groups was intermediate between 0 and 4-day preculture groups for the appropriate GRF-treatment. There was a dose-related increase in IGH secretion which appeared to have reached maximum at $5 \mathrm{nM}$ (or less), with the exception of the one anomaly (0-day preculture / $20 \mathrm{nM}$ GRF). The BGH and IGH secretion for experiment

\footnotetext{
1 Four rats died over the course of the assay. Cause of death was not determined.
} 
$B 2$ is shown in Figure 3. The results for BGH secretion reveal the same basic pattern as those for IGH secretion in experiment $B 1$ (panel B, Figure 2). That is, with increasing duration of preculture, both basal and GRF-stimulated secretion during the 4-hour treatment period declined. Secretion of BGH for the 4-day preculture group, expressed as a percent of the 0-day preculture group, was $49 \%, 53 \%$, and $74 \%$ for 0,5 , and $20 \mathrm{nM}$ GRF treatments, respectively. With the exception of the 0-day preculture / $0 \mathrm{nM}$ GRF group and the 2-day preculture / $20 \mathrm{nM}$ GRF group, all values were intermediate between 0 and 4-day preculture groups for the appropriate treatment condition. There was a dose-related increase in $B G H$ secretion which appeared to have not yet reached maximum at $20 \mathrm{nM}$ GRF. The results for IGH secretion in experiment B2 (panel B, Figure 3) reveal the same basic pattern as the IGH results for experiment $\mathrm{B} 1$ and the $\mathrm{BGH}$ results for experiment B2. With increasing durations of preculture, both basal and GRF-stimulated IGH secretion during the 4-hour treatment period declined. Secretion of IGH for the 4-day preculture group expressed as a percent of the 0-day preculture group, was $50 \%, 18 \%$, and $22 \%$, for the 0,5 , and $20 \mathrm{nM}$ GRF treatments, respectively. With only one exception (1-day preculture / $0 \mathrm{nM}$ GRF), IGH secretion for the 2 and 4-day preculture groups was intermediate between the 0 and 4-day groups for the appropriate treatment. There was a dose-related increase in IGH secretion which appeared to have plateaued at about $5 \mathrm{nM}$. 

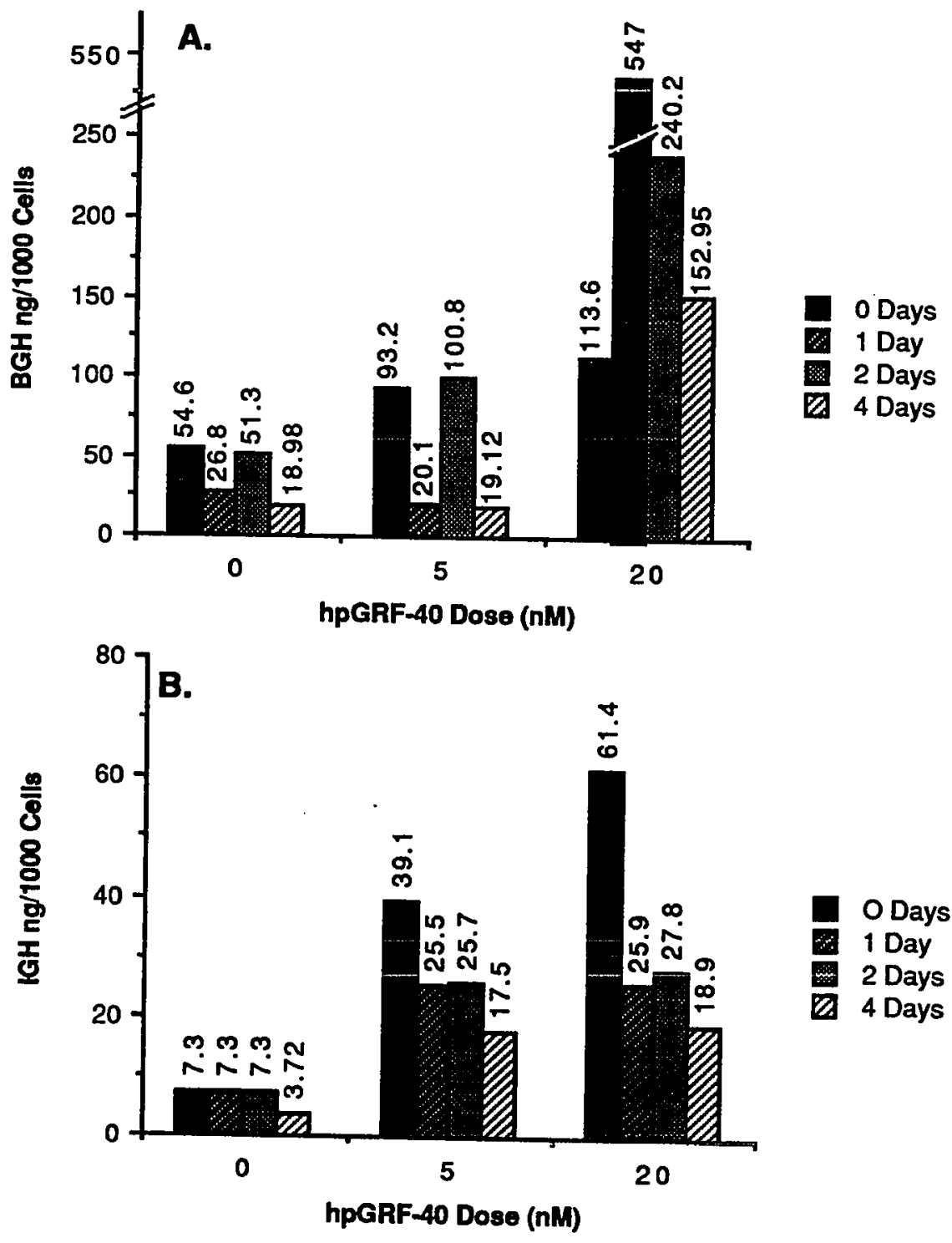

Figure 2. The effect of increasing durations of preculture of mixed somatotrophs on basal and hpGRF-40 stimulated BGH release (panel A), and IGH release (panel B) during a 4-hour treatment period. All values are the result of a single determination in experiment B1. 

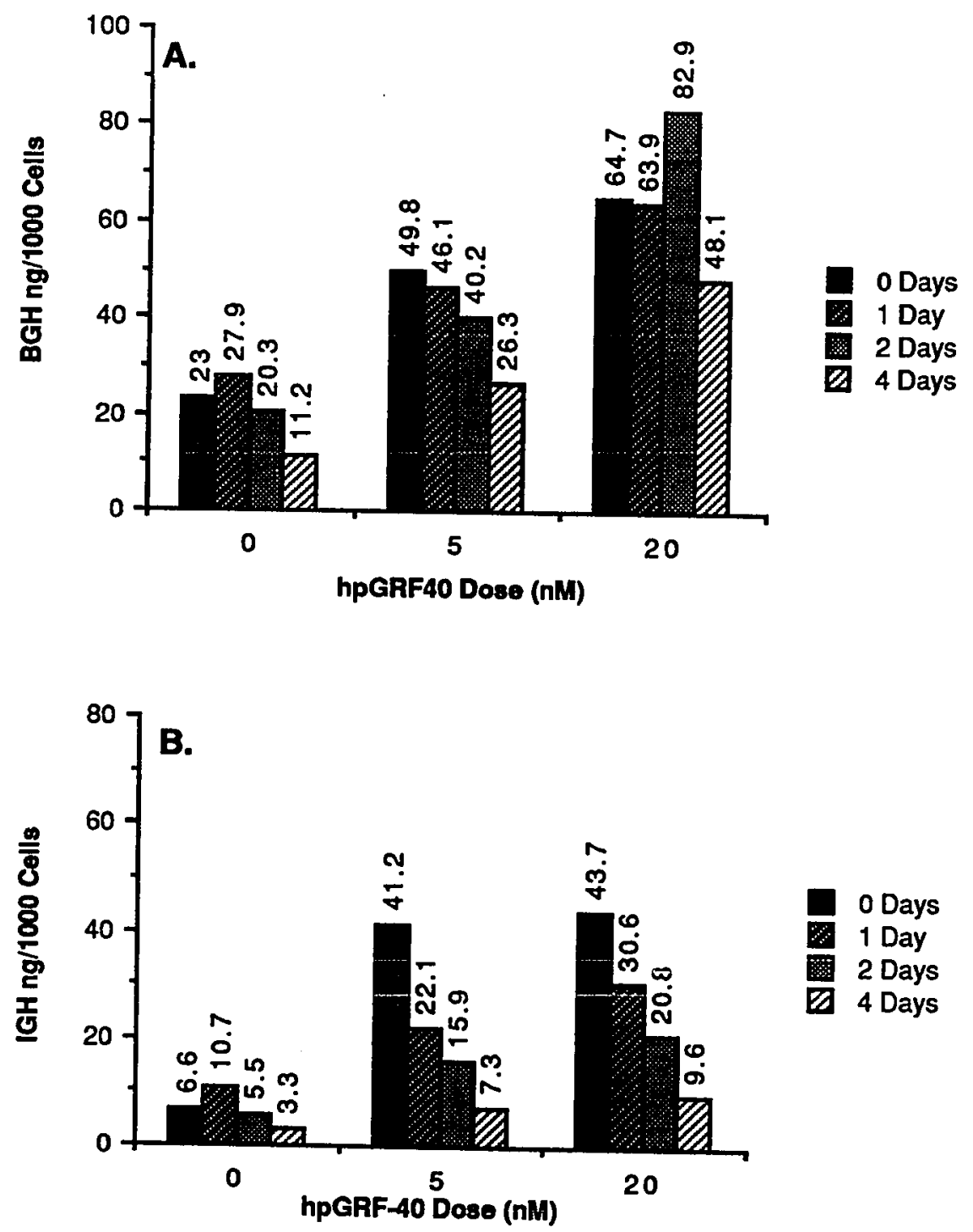

Figure 3. The effect of increasing durations of preculture of mixed somatotrophs on basal and hpGRF-40 stimulated BGH release (panel A), and IGH release (panel B) during a 4-hour treatment period. All values are the result of a single determination in experiment B2. 
The results indicated that when maximal IGH and $B G H$ secretion are used as an index for optimal cell "performance," then the preculture period of 3 to 5 days used by most researchers compromises secretory function. Indeed the results of the duplicate experiments presented here indicate that both basal and GRFstimulated BGH and IGH secretion progressively decline with increasing duration of preculture. On the basis of these two experiments, the 3 to 5 -day preculture period was eliminated in subsequent experiments using GRF-stimulation of GH secretion. In all subsequent experiments, cells were treated on the same day the rats were terminated (i.e., without a preculture period).

\section{Experiment C: Effects of Culture Conditions on Basal and hpGRF-Stimulated IGH Secretion}

Experiment $C$ investigated the effects of closed culture flasks filled with air only (C/A), closed culture flasks filled with $95 \%$ air / $5 \% \mathrm{CO}_{2}(\mathrm{C} / \mathrm{C})$, and open culture flasks exposed continuously to $95 \%$ air / $5 \% \mathrm{CO}_{2}$ in a humidified incubator $(\mathrm{O} / \mathrm{C})$ on basal and GRF-stimulated IGH secretion. Postdissociation cell viability was $91 \%$. Day 2 post-treatment cell viability was $96 \%$ among all 3 groups. On day 4 , the posttreatment cell viabilities were $89 \%$ in the closed system groups (C/C and $C / A)$, and $93 \%$ in the open system group (0/C). The results for IGH secretion during preculture are shown in Figure 4 (panel A). All bars represent means for duplicate 
determinations, which are indicated as individual data points within the figure. Mean values for IGH concentration for all preculture groups (panel A) ranged between 2.8 and $3.4 \mu \mathrm{g} / \mathrm{mL}$, with no definite pattern between groups for either 2-day or 4day preculture media. It appears that the IGH concentrations between 2 and 4-day preculture groups did not differ. The results for IGH secretion during the 4-hour GRF-treatment period are shown in Figure 4 (panel B). The mean IGH secretion values for the 2-day preculture GRF-treated groups ranged between 4.7 and $4.8 \mu \mathrm{g} / \mathrm{mL}$ media. It appears that there were no differences between treatment groups for the 2-day preculture GRF-treatment condition. The mean IGH secretion values ranged between 3.7 and $4.8 \mu \mathrm{g} / \mathrm{mL}$ media. The open system group (O/C) had $14 \%$ greater GRF-stimulated IGH secretion than the closed-system groups. Mean IGH secretion for all three 2-day preculture/GRF-treated groups was 4.74 $\mu \mathrm{g} / \mathrm{mL}$, while the corresponding value for the 4-day preculture group was $3.88 \mu \mathrm{g} / \mathrm{mL}$. The difference between these averaged values was $18 \%$. Experiment $C$ was performed because experiment $B$ cells were incubated in culture flasks with closed caps, thus preventing gas exchange with the external environment. Since this reduces the amount of $\mathrm{O}_{2}$ available to cells and results in an accumulation of $\mathrm{CO}_{2}$, it was thought that these effects might have contributed to the observed 


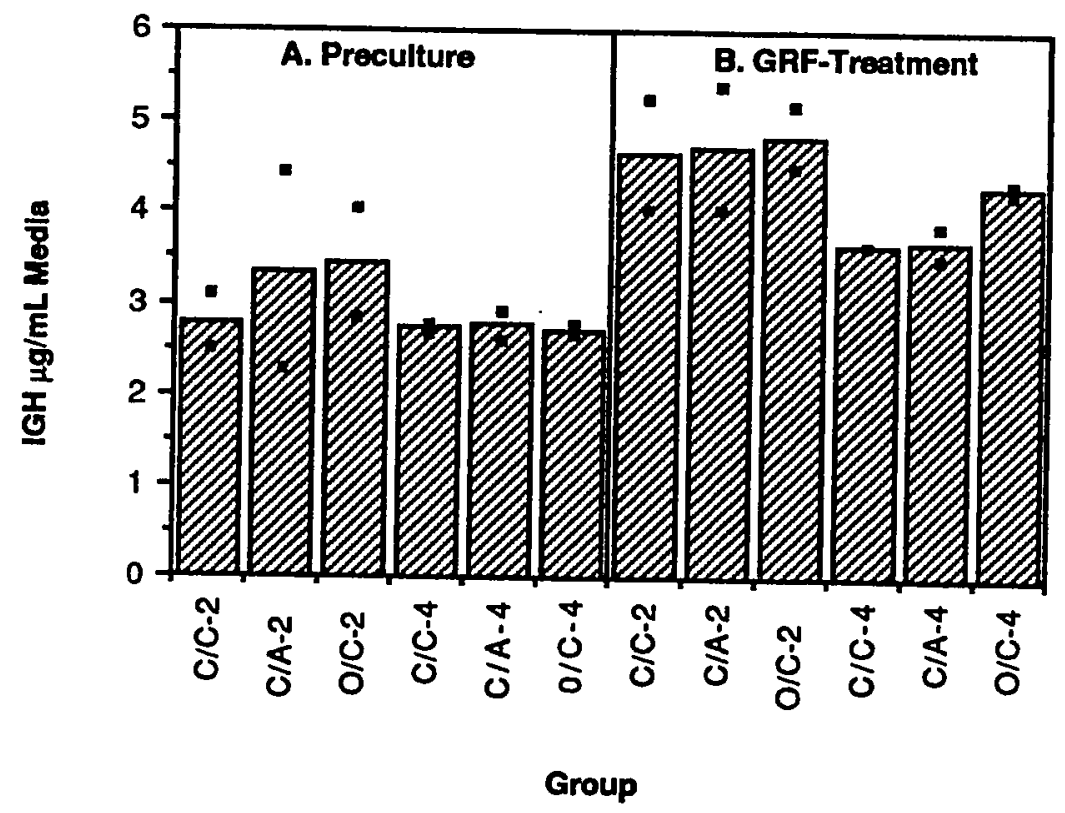

Figure 4. The effect of various culture conditions on basal (panel A) and hpGRF-40 stimulated (panel B) IGH release. Basal IGH secretion was determined at days 2 and 4 of the culture period, as was GRF-stimulated secretion (4-hour treatments). The culture conditions were: closed flasks charged with $5 \% \mathrm{CO}_{2} / 95 \%$ air $(\mathrm{C} / \mathrm{C})$; closed flasks charged with air only $(\mathrm{C} / 0)$; and open-system culture flasks constantly exposed to $5 \%$ $\mathrm{CO}_{2} / 95 \%$ humidified air (0/C). The label for each bar is followed by the duration of culture prior to collecting media (panel A; either 2 or 4 days), or prior to GRFtreatment (panel B; either 2 or 4 days). Data points for duplicate determinations are included to show the response variability.

results in experiment $B$. It should be noted that the choice of the "closed system" in experiment B was based on the demonstration by W. Hymer that rat pituitary cells cultured for 4 days in closed 4.8 $\mathrm{mL}$ glass vials with only $0.8 \mathrm{~mL}$ air secrete $\mathrm{GH}$ at the same rate as control cells cultured in "open system" plastic culture plates $(2 \mathrm{~mL}$ well volume) exposed to $95 \%$ air-5\% $\mathrm{CO}_{2}$ (personal communication). The results of experiment $\mathrm{C}$ are consistent with those of Hymer, and 
indicate that it is unlikely that the progressively decreasing basal and GRF-stimulated BGH and IGH secretion found with increasing duration of preculture (experiment B) were due to use of the "closed system" culture.

\section{Experiment D: Determination of GH Stability in}

\section{Culture Media}

Post-dissociation cell viability was $91 \%$. Viabilities on days $1,2,3$, and 4 were $84,97,95$, and $96 \%$, respectively. The hGH concentrations in media incubated from 0-4 days are shown in Figure 5 (panel A). Media were not collected on day 3. The hGH concentrations in media incubated with cells for 0-4 days are shown in Figure 5 (panel B). The bars for both panels represent mean values. Error bars represent the standard error of the mean for 6 determinations. The maximum deviation from the presumed absolute starting hGH concentration of $5 \mu \mathrm{g} / \mathrm{mL}$ was not more than $10 \%$ for either media incubated alone or in the presence of cells. No pattern of degradation with respect to time is suggested by the results shown in Figure 5. The timecourse of secretion of rat IGH over the 4-day culture period is shown in Figure 6. The dark bars represent rat $\mathrm{IGH} \mu \mathrm{g} / \mathrm{mL}$ media for cells incubated in media C (MEM) alone, while the hatched bars represent the same values for cells incubated in media $\mathrm{C}$ containing $5 \mu \mathrm{g}$ hGH per $\mathrm{mL}$ media $(M E M+G H)$. Secretion for both groups was linear over time, and as can be seen in the figure, 5 $\mu \mathrm{g} \mathrm{hGH}$ per $\mathrm{mL}$ media did not inhibit release of native rat $\mathrm{GH}$ into 
media. The mean values for $1 G H$ secretion for both treatment groups were combined to yield the linear regression equation for IGH secretion over the 4 day period: Secretion $(\mu \mathrm{g} / \mathrm{mL})=1.855 \mu \mathrm{g} \mathrm{X}$ $\mathrm{mL}^{-1} X$ day- $^{-1} \mathrm{X}$ days +0.997 . The Pearson correlation coefficient for the equation above was 0.994 .

The results of this experiment indicated that pituitary-derived 191-amino acid human GH is stable for at least four days when cultured in the presence of mixed rat somatotrophs. Additionally, the data indicated that human $\mathrm{GH}$ at these concentrations does not exert a negative feedback effect on rat IGH secretion over a four-day culture period. Moreover, the data suggest that rat GH secreted into media does not exert a negative feedback effect on rat IGH secretion, since rat $\mathrm{GH}$ secretion was highly linear with respect to time in days as shown by the above linear regression equation and correlation coefficient using data from media alone and media supplemented with human GH. It appears therefore, that with the culture conditions used in these experiments negative feedback of secreted IGH is not an important factor in explaining results. 


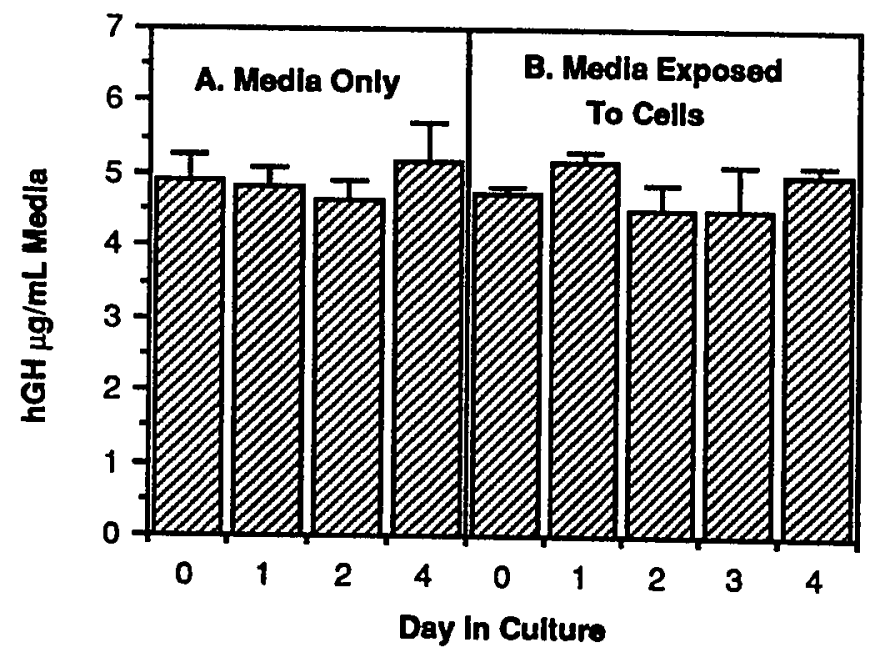

Figure 5. The effect of culture duration on degradation of human immunoreactive GH in media containing $5 \mu \mathrm{g} \mathrm{hGH}$ per $\mathrm{mL}$ (panel A) and the same media in the presence of $1.5 \times 10^{5}$ mixed rat adenohypophyseal cells per $\mathrm{mL}$ media (panel B). Each bar represents the mean \pm S.E.M. for 6 wells containing 1 $\mathrm{mL}$ of solution each.

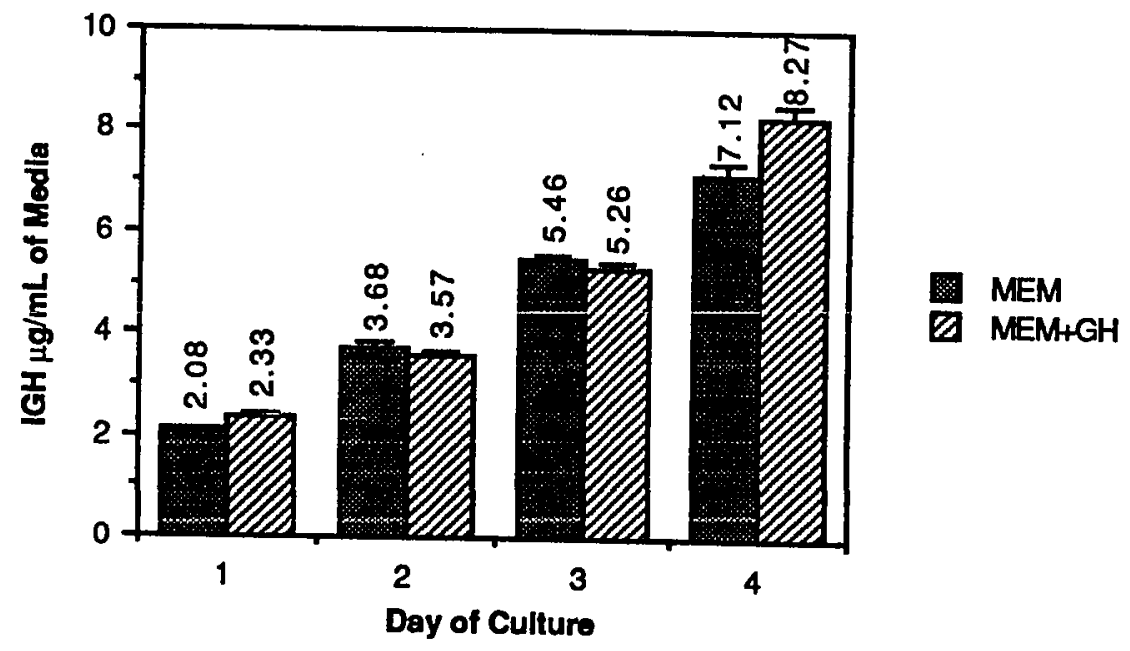

Figure 6. Secretion of rat immunoreactive GH from mixed rat adenohypophyseal cells incubated in culture media alone (MEM), or media containing $5 \mu \mathrm{g} \mathrm{hGH}$ per $\mathrm{mL}$. Each bar represents the mean \pm S.E.M. for 6 wells containing $1 \mathrm{~mL}$ of solution each. Numeric values for mean GH secretion are also indicated. 


\section{Experiment E: Validation of Cell Separation Procedure}

\section{- Single Phase Method}

Post-dissociation cell viability was $88 \%$. Post-gradient cell viabilities for type 1 and type 2 cells were $76 \%$ and $44 \%$, respectively. At the end of the 12-day culture period, the mixed, type 1, and type 2 cell viabilities were $85 \%, 89 \%$, and $11 \%$, respectively. The results for secreted $\mathrm{GH}$ in experiment $\mathrm{E}$ are summarized in Table 3. Type 1 cells released slightly less BGH than mixed cells over the 12-day culture, while type 2 cells released nearly twice as much BGH as mixed cells. In contrast, type 1 cells released about 1.5-times more IGH than mixed cells, while type 2 cells released about 1.5-times less IGH than mixed cells. For mixed and type 1 cells BGH secretion increased and then decreased in successive 4-day culture intervals. Type 2 cell BGH secretion progressively increased in successive 4-day culture intervals. BGH secretion for both mixed and type 1 cells increased and then decreased during days 5-8, and 9-12, respectively. IGH secretion from mixed cells increased and then decreased in successive 4-day culture intervals. IGH secretion from type 1 and type 2 cells progressively decreased during successive 4-day culture intervals. The differences in forms of GH released from the 2 cell types are most dramatically illustrated by the BGH/IGH ratio for the total $\mathrm{GH}$ released over the 12-day culture. The ratios for mixed, type 1, and type 2 cells were 3.6, 2.0, and 10.8, respectively. A pattern similar to that for total hormone released can be seen for both absolute 
amounts of $\mathrm{GH}$ released and $\mathrm{BGH} / \mathrm{IGH}$ ratios for the 0-4 day secretion.

The results of this experiment, using the single density BSA gradient separation procedure, were in general agreement with published results describing the differences between cell types [98, 99]. The general agreement was interpreted as evidence of successful somatotroph separation, indicating that the procedure could be used in subsequent experiments. However, as mentioned above, it was recommended to the author that the 2-density BSA gradient separation scheme be used in subsequent experiments since that procedure had been utilized in most published experiments, and was thus better established.

\section{TABLE 3}

BGH and IGH Secretion in Mixed, Type 1, and Type 2 Somatotrophs Cultured for 12 Days

(Values in $\mathrm{ng}$ GH per 1000 cells seeded; three successive 4-day intervals plus cumulative totals) Mixed Cells Type 1 Cells Type 2 Cells

\begin{tabular}{|l||c|c|c||c|c|c||c|c|c|}
\hline & BGH & IGH & BGHIGH & BGH & IGH & BGHIGH & BGH & IGH & BGHIGH \\
\hline \hline Days 0-4 & 60.9 & 22.7 & 2.7 & 11.2 & 52.7 & 0.21 & 110 & 40.4 & 2.7 \\
\hline Days 5-8 & 127 & 32.0 & 4.0 & 171 & 48.2 & 3.6 & 185 & 8.8 & 20 \\
\hline Days 9-12 & 104 & 26.3 & 3.9 & 71.8 & 27.2 & 2.6 & 279 & 3.8 & 74 \\
\hline 12 day total & 292 & 81 & 3.6 & 254 & 128 & 2.0 & 574 & 53 & 10.8 \\
\hline
\end{tabular}




\section{Experiment F: Validation of Cell Separation Procedure - 2-}

\section{Phase Method}

Post-dissociation cell viability was $89 \%$. Post-gradient cell viabilities were $84 \%$ for type 1 and $68 \%$ for type 2 cells. Mixed cell viability at recovery on days 4,8 , and 12 were $94 \%, 94 \%$, and $82 \%$, respectively. Type 1 cell viability at recovery on days 4,8 , and 12 were $83 \%, 94 \%$, and $86 \%$, respectively. Type 2 cell viability at recovery on days 4,8 , and 12 were $83 \%, 96 \%$, and $71 \%$, respectively. The percentage somatotrophs in mixed, type 1 , and type 2 cell fractions were $44.8,17.4$, and $77.6 \%$, respectively. The results for BGH and IGH secretion expressed on a per 1000 cells seeded basis are summarized in Table 4. The data shown in Table 4 were transformed into the per 1000 somatotroph data shown in Table 5 by using the percentage somatotroph values obtained from the immunocytochemistry procedure. The values shown allow for a more direct comparison between somatotroph types than the data in Table 4. In each of the successive 4-day culture intervals shown in Tables 4 and 5, the type 2 cell BGH/IGH ratio was greatest (7.6-20), followed by mixed cells (1.7-7.7), and finally type 1 cells (0.3-1.5). As shown in Table 5, BGH secretion was greatest in the type 2 cells, followed by type 1 cells, and then mixed cells. IGH secretion was greatest in the type 1 cells, followed by mixed cells and then type 2 cells. The aforementioned patterns in cell response are also reflected in the 4-day secretory data. BGH production in type 2 cells (Table 5) was 2.6-times greater than mixed cells, and 1.7-times 
greater than type 1 cells over the 12-day culture. BGH secretion in type 2 cells was 2.5-times greater than mixed cells, and 1.7-times greater than type 1 cells over the 12-day culture. IGH production in type 1 cells was 6.1-times greater than mixed cells, and 14-times greater than type 2 cells over the 12-day culture. IGH secretion in type 1 cells was 5.4-times greater than mixed cells, and 9.8-times greater than type 2 cells over the 12-day culture. These basic patterns were also reflected in the 4-day secretion data (Table 5).

The results of this experiment, using the two density BSA gradient separation procedure, were in agreement with published results describing the differences between cell types [98, 99]. The agreement was interpreted as evidence of successful somatotroph separation, indicating that the procedure could be used successfully in subsequent experiments. 


\section{TABLE 4}

BGH and IGH Secretion From 12-Day Cultures of Mixed, Type 1, and Type 2 Somatotrophs Expressed on a Per Cell Basis.

(Values in ng GH per 1000 cells seeded; three successive 4-day intervals plus cumulative totals; start and end extracts used for determination of GH production)

Mixed Cells

Iype 1 Cells

Iype 2 Cells

\begin{tabular}{|l||c|c|c||c|c|c||c|c|c|}
\hline & BGH & IGH & BGH/GH & BGH & IGH & BGH/GH & BGH & IGH & BGH/IGH \\
\hline \hline $\begin{array}{l}\text { Start } \\
\text { Extract }\end{array}$ & 11.1 & 11.3 & 1.0 & 5.06 & 1.55 & 3.3 & 63.6 & 27.1 & 2.3 \\
\hline Days 0-4 & 59.7 & 35.1 & 1.7 & 46.3 & 43.4 & 1.1 & 624 & 31.3 & 20 \\
\hline Days 5-8 & 111 & 14.3 & 7.8 & 78.3 & 51.5 & 1.5 & 295 & 19.4 & 15 \\
\hline Days 9-12 & 69.6 & 20.8 & 3.3 & 17.2 & 52.2 & 0.3 & 126 & 16.6 & 7.6 \\
\hline 12 day total & 240 & 70 & 3.4 & 142 & 147 & 1.0 & 1044 & 67 & 16 \\
\hline End Extract & 12.7 & 4.22 & 3.0 & 7.11 & 3.74 & 1.9 & 101 & 7.58 & 13 \\
\hline Production & 241 & 63 & 3.8 & 144 & 149 & 1.0 & 1082 & 47.8 & 23 \\
\hline
\end{tabular}




\section{TABLE 5}

BGH and IGH Secretion From 12-Day Cultures of Mixed, Type 1, and Type 2 Somatotrophs Expressed on a Per Somatotroph Basis.

(Values in ng GH per 1000 somatotrophs seeded; three successive 4-day intervals plus cumulative totals; start and end extracts used for determination of $\mathrm{GH}$ production)

Mixed Somatotrophs Iype 1 Somatotrophs Iype 2 Somatotrophs

\begin{tabular}{|c|c|c|c|c|c|c|c|c|c|}
\hline & BCH & $\mathrm{IGH}$ & BGH/IGH & $\mathrm{BGH}$ & ICH & $\mathrm{BGH} / \mathrm{IGH}$ & BGH & IGH & $\mathrm{BGH} / \mathrm{IGH}$ \\
\hline $\begin{array}{l}\text { Start } \\
\text { Extract }\end{array}$ & 24.8 & 25.2 & 1.0 & 6.52 & 2.00 & 3.3 & 81.9 & 34.9 & 2.4 \\
\hline Days $0-4$ & 133 & 78.3 & 1.7 & 266 & 249 & 1.1 & 804 & 40.3 & 20 \\
\hline Days 5-8 & 248 & 31.9 & 7.7 & 450 & 296 & 1.5 & 380 & 25.0 & 15 \\
\hline Days 9-12 & 155 & 46.4 & 3.3 & 99.0 & 300 & 0.3 & 162 & 21.4 & 7.6 \\
\hline 12 day total & 536 & 156 & 3.4 & 812 & 843 & 1.0 & 1346 & 86.3 & 16 \\
\hline End Extract & 28.3 & 9.42 & 3.0 & 40.9 & 21.5 & 1.9 & 130 & 9.77 & 13 \\
\hline Production & 539 & 140 & 3.8 & 825 & 856 & 1.0 & 1394 & 61.6 & 23 \\
\hline
\end{tabular}

\section{Experiment G: Type One and Type Two Somatotroph}

\section{Response to rGRF-43}

Post-dissociation cell viability was $92 \%$. Post-gradient cell viabilities were $81 \%$ for type 1 and $40 \%$ for type 2 cells. No posttreatment viability determinations were made. The percentage somatotrophs in mixed, type 1, and type 2 cells were 48.9, 20.7, and $73.6 \%$, respectively. The complete results, with the exception of BGH results for 12.5 , and $400 \mathrm{nM}$ GRF, are shown in Table 6. These same results are graphically represented for IGH only (Figure 7). Of the BGH values presented in Table 6, five of the dilution "curves" for 
high and low doses were non-parallel to the standard "curve" when tested at alpha $=0.05$ in the multiple regression test. Those groups were: mixed cells - $6.25 \mathrm{nM}$ GRF; type 2 cells - $0.39 \mathrm{nM}$ GRF; and type 2 cells - $3.13 \mathrm{nM}$ GRF. The reason for deviation from the standards is not known. However, it was not due to the low dose not differing from saline controls, as the low dose tibial readings in all cases were well beyond saline readings. The values shown for these groups should be considered as an estimate only. In two assay samples, the low dose tibial readings did not differ from salineinjected controls. Consequently, the values obtained were based on the high dose tibial readings alone. Those groups were: mixed cells 0 nM GRF; and type 1 cells $-0.78 \mathrm{nM}$ GRF. When the results for GRFstimulated BGH and IGH secretion from the three different groups of cells are examined (Table 6, Figure 7), it appears that maximal secretion was obtained at $1.56 \mathrm{nM}$ GRF in all cases, with the exception of IGH secretion for type 2 cells (which peaked at 3.13 $n M)$. Progressive increases in both BGH and IGH release are seen for both mixed and type 1 cells over the dose range of 0 to $1.56 \mathrm{nM}$. Progressive increases in IGH release are seen for type 2 cells over the GRF dose range of 0 to $3.13 \mathrm{nM}$ (Figure 6), but similar increases are not seen for BGH (consequently BGH data were not graphically plotted). BGH secretion for type 2 cells started at $168 \mathrm{ng} / 1000$ somatotrophs at $0 \mathrm{nM}$ GRF, decreased to as low as $63.7 \mathrm{ng} / 1000$ somatotrophs at $0.78 \mathrm{nM} \mathrm{GRF,} \mathrm{and} \mathrm{finally} \mathrm{increased} \mathrm{to} 528 \mathrm{ng} / 1000$ somatotrophs at $1.56 \mathrm{nM}$ GRF. The BGH and IGH secretion data from 
Table 6 were used to determine the percent increase over control (0 $\mathrm{nM}) \mathrm{GH}$ secretion at the plateau dose (1.56 nM; $3.13 \mathrm{nM}$ for type 2 IGH). Those results are shown in Table 7. It can be seen that the percent increase in BGH secretion from type 2 cells (310) was considerably lower than the values for either mixed or type 1 cells. The maximal percent increase in IGH secretion was about the same for mixed and type 2 cells, but slightly higher for type 1 cells (Table 7). It can be seen in Table 6 that the supra-maximal (>1.56 nM) GRF doses produced erratic results for BGH secretion in all three cell groups. The results for $1 \mathrm{GH}$ secretion yielded an interesting biphasic response. It can be seen in Table 6 that for all 3 cell types, GRFstimulated IGH secretion declined at doses 2- and 4-times greater than the maximal response, and then increased with further increases in dose beyond the nadir. Despite the post-nadir increases, $400 \mathrm{nM}$ GRF-stimulated IGH secretion in no case exceeded that of the maximal dose (Table $6-400 \mathrm{nM}$ vs 1.56 or $3.13 \mathrm{nM}$ GRF). In general the BGH/IGH ratios for type 2 cells at the various GRF doses were considerably higher than either mixed or type 1 cell $\mathrm{BGH} / \mathrm{IGH}$ ratios (Table 6). In general, type $1 \mathrm{cell} \mathrm{BGH} / \mathrm{IGH}$ ratios were not different from the corresponding mixed cell ratios. The results of this experiment demonstrated that treatment of mixed, type 1, or type 2 cells with rGRF-43 causes release of both $\mathrm{BGH}$ and IGH from each group of cells. Moreover, with the exception of $\mathrm{BGH}$ secretion from type 2 cells, the maximal GRF-stimulated percent-increase over control BGH and IGH secretion were similar 
between the 3 groups of cells. The selective release of BGH under conditions of stress thus does not appear to be explainable on the basis of GRF stimulation alone, a conclusion consistent with the hypothesis of this thesis.

\section{Bioassayable and Immunoassayable Growth Hormone Secretion in Response to Rat Hypothalamic GRF-43}

(values are ng per 1000 somatotrophs seeded)

BGH

IGH

BGH/IGH

\begin{tabular}{|c||c|c|c|c|c|c||c|c|c|}
\hline $\begin{array}{c}\text { GF } \\
\text { Dose }\end{array}$ & $\begin{array}{c}\text { Mixed } \\
\text { Cells }\end{array}$ & $\begin{array}{c}\text { Type 1 } \\
\text { Cells }\end{array}$ & $\begin{array}{c}\text { Type 2 } \\
\text { Cells }\end{array}$ & $\begin{array}{c}\text { Mixed } \\
\text { Cells }\end{array}$ & $\begin{array}{c}\text { Type 1 } \\
\text { Cells }\end{array}$ & $\begin{array}{c}\text { Type 2 } \\
\text { Cells }\end{array}$ & $\begin{array}{c}\text { Mixed } \\
\text { Cells }\end{array}$ & $\begin{array}{c}\text { Type 1 } \\
\text { Cells }\end{array}$ & $\begin{array}{c}\text { Type 2 } \\
\text { Cells }\end{array}$ \\
\hline $0 \mathrm{nM}$ & 30.3 & 41.3 & 168 & 14.9 & 15.7 & 11.6 & 2.0 & 2.6 & 14.5 \\
\hline $0.39 \mathrm{nM}$ & 39.8 & 42.2 & 111 & 34.1 & 29.5 & 26.6 & 1.2 & 1.4 & 4.2 \\
\hline $0.78 \mathrm{nM}$ & 43.3 & 95.7 & 63.7 & 41.4 & 38.3 & 33.3 & 1.0 & 2.5 & 1.9 \\
\hline $1.56 \mathrm{nM}$ & 152 & 229 & 528 & 63.5 & 77.8 & 48.2 & 2.4 & 3.0 & 10.9 \\
\hline $3.13 \mathrm{nM}$ & 127 & 66.8 & 321 & 54.3 & 67.6 & 58.4 & 2.3 & 1.0 & 5.5 \\
\hline $6.25 \mathrm{nM}$ & 168 & 213 & 262 & 49.8 & 54.2 & 50.3 & 3.4 & 3.9 & 5.2 \\
\hline $12.5 \mathrm{nM}$ & $\mathrm{n} / \mathrm{a}$ & $\mathrm{n} / \mathrm{a}$ & $\mathrm{n} / \mathrm{a}$ & 49.4 & 42.2 & 44.2 & $\mathrm{n} / \mathrm{a}$ & $\mathrm{n} / \mathrm{a}$ & $\mathrm{n} / \mathrm{a}$ \\
\hline $25 \mathrm{nM}$ & 199 & 125 & 429 & 57.7 & 52.1 & 55.9 & 3.4 & 2.4 & 7.7 \\
\hline $100 \mathrm{nM}$ & 219 & 250 & 423 & 51.0 & 64.2 & 64.2 & 4.3 & 3.9 & 6.6 \\
\hline $400 \mathrm{nM}$ & $\mathrm{n} / \mathrm{a}$ & $\mathrm{n} / \mathrm{a}$ & $\mathrm{n} / \mathrm{a}$ & 44.5 & 69.3 & 58.8 & $\mathrm{n} / \mathrm{a}$ & $\mathrm{n} / \mathrm{a}$ & $\mathrm{n} / \mathrm{a}$ \\
\hline
\end{tabular}




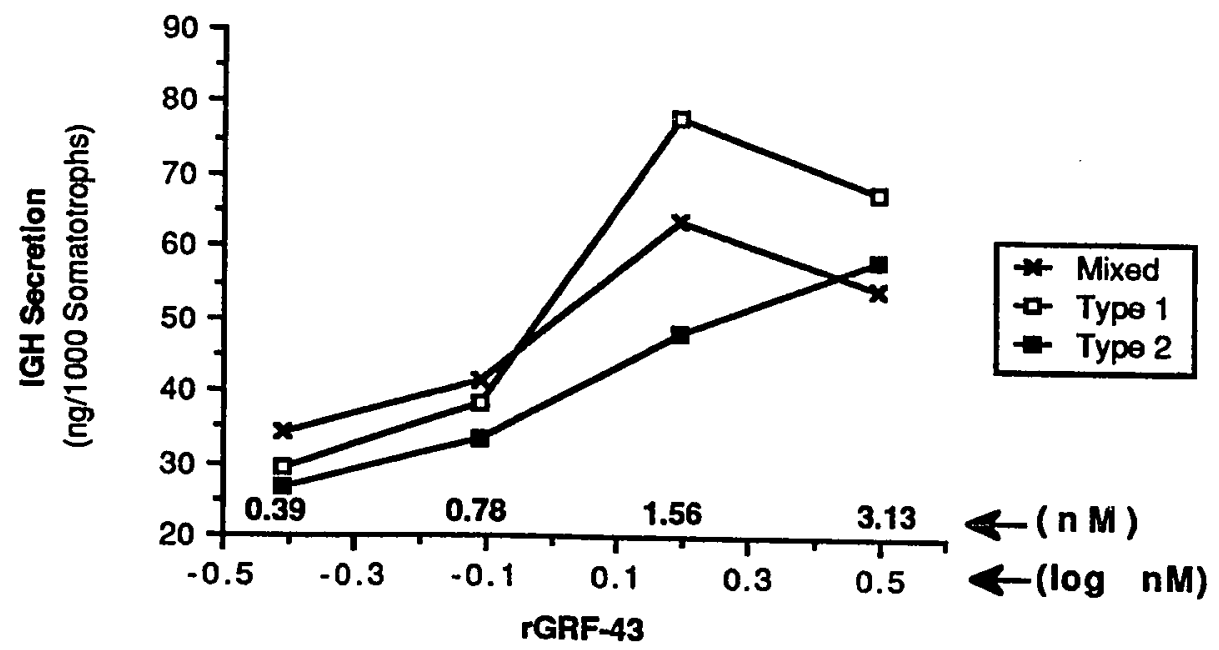

Figure 7. Immunoreactive rat GH secretion in response to rGRF-43 in mixed, type 1 , and type 2 cell types. Log dose is plotted below the abcissa, while actual GRF dose in $\mathrm{nM}$ is indicated above the abcissa.

\section{TABLE 7}

$\begin{array}{cccc}\begin{array}{c}\text { Maximal rGRF-43-Stimulated } \\ \text { Over Control BGH and IGH }\end{array} & \begin{array}{c}\text { Percent-Increase } \\ \text { Secretion }\end{array} \\ & \text { Mixed Cells } & \text { Iype 1 Cells } & \text { Iype 2 Cells } \\ \text { BGH: } & 510 & 554 & 314 \\ \text { IGH: } & 436 & 469 & 416\end{array}$




\section{Experiment H: Effects of BSA Incubation on Cell Viability and $\mathbf{G H}$ Secretion}

For experiment $H 1$, post-dissociation cell viability was $89 \%$ while the viability immediately after the 45-minute BSA-incubation was $87 \%$. Following the 4-hour GRF treatment period, viabilities for the BSA-incubated group (BSA), and the group incubated at room temperature $\left(\mathrm{RT} ; 22-24^{\circ} \mathrm{C}\right.$ ) were $80 \%$ and $69 \%$, respectively. Viability determinations were not done for the cold-treated group. For experiment $\mathrm{H} 2$, post-dissociation cell viability was $92 \%$ while the viability immediately after the 45-minute BSA-incubation was $91 \%$. Following the 4-hour GRF treatment period, viabilities for the BSA-incubated group, RT group, and cold-treated group were $82 \%$, $87 \%$, and $88 \%$, respectively. The results for $B G H$ and IGH secretion for experiment $\mathrm{H} 1$ are shown in Figure 8, panel $A$ and $B$, respectively. The results for $B G H$ and $I G H$ secretion for experiment $H 2$ are shown in Figure 9, panel $A$ and $B$, respectively. In Figure $8 A$ it can be seen that 4-hour treatment with GRF (experiment $H 1$ ) caused a large increase in BGH secretion. The increase was about 3.4-times for the RT group, and 6.5-times for the BSA group. Samples from the coldtreated group were not bioassayed. GRF-stimulated $B G H$ secretion was 1.4-times greater in the BSA group than in the RT group, while the differences between basal secretion appeared to be insignificant. In Figure 8B it can be seen that, for experiment H1, 4hour treatment with GRF also caused a large increase in IGH secretion. The $0.5 \mathrm{nM}$ dose produced about 5-, 7.5-, and 4-times 
increases over basal IGH secretion in RT, BSA, and cold-treated cell groups, respectively. The $1.5 \mathrm{nM}$ dose produced about

6-, 9-, and 9.5-times increases over basal IGH secretion in RT, BSA, and cold-treated cell groups, respectively. Basal IGH secretion did not differ between groups.

In Figure 9A it can be seen that 4-hour treatment with GRF (experiment H2) also caused a large increase in BGH secretion. The $0.17 \mathrm{nM}$ dose produced increases of about 1.8-times for the RT group, and 2-times for the BSA group. The $0.5 \mathrm{nM}$ dose produced increases of about 2.4-times for the RT group, and 2.1-times for the BSA group. Samples from the cold-treated group, and 1.5 nM GRF-treated groups were not bioassayed. GRF-stimulated BGH secretion was 1.3 to 1.5-times greater in the RT group than in the BSA group at all GRF treatment doses. In Figure $9 \mathrm{~B}$ it can be seen that 4-hour treatment with GRF (experiment H2) also caused a large increase in IGH secretion. The $0.17 \mathrm{nM}$ dose produced about 2.3-times increases over basal IGH secretion in all treatment groups. The $0.5 \mathrm{nM}$ dose produced about 6-times increases over basal IGH secretion in all treatment groups. The $1.5 \mathrm{nM}$ dose produced about 8-times increases over basal IGH secretion in all treatment groups. Numeric precision between groups was excellent for this experiment.

These two experiments investigated the effect of BSA incubation and exposure of cells to $4^{\circ} \mathrm{C}$ on cell viability and both basal and GRF-stimulated BGH and IGH secretion. The results showed that neither BSA incubation nor exposure to cold affect 
basal or GRF-stimulated BGH or IGH secretion. These experiments were important in order to be certain that differences between cell types in the cell separation experiments are not an artifact of the separation procedure. 


\section{A. BGH Secretion}

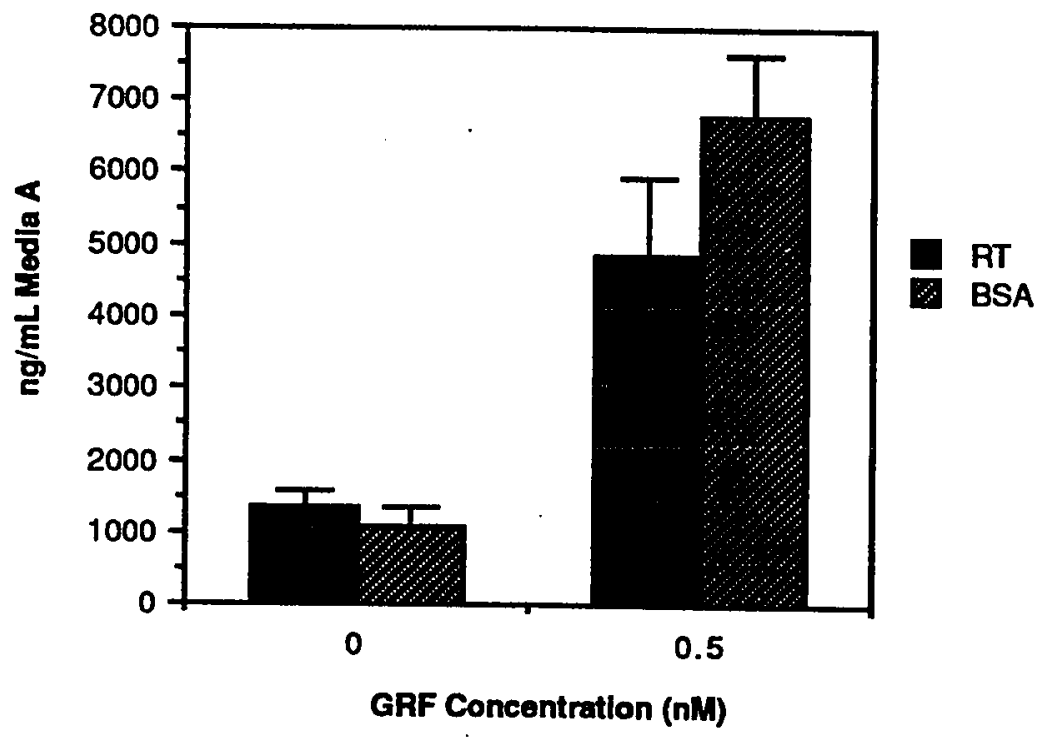

B. IGH Secretion

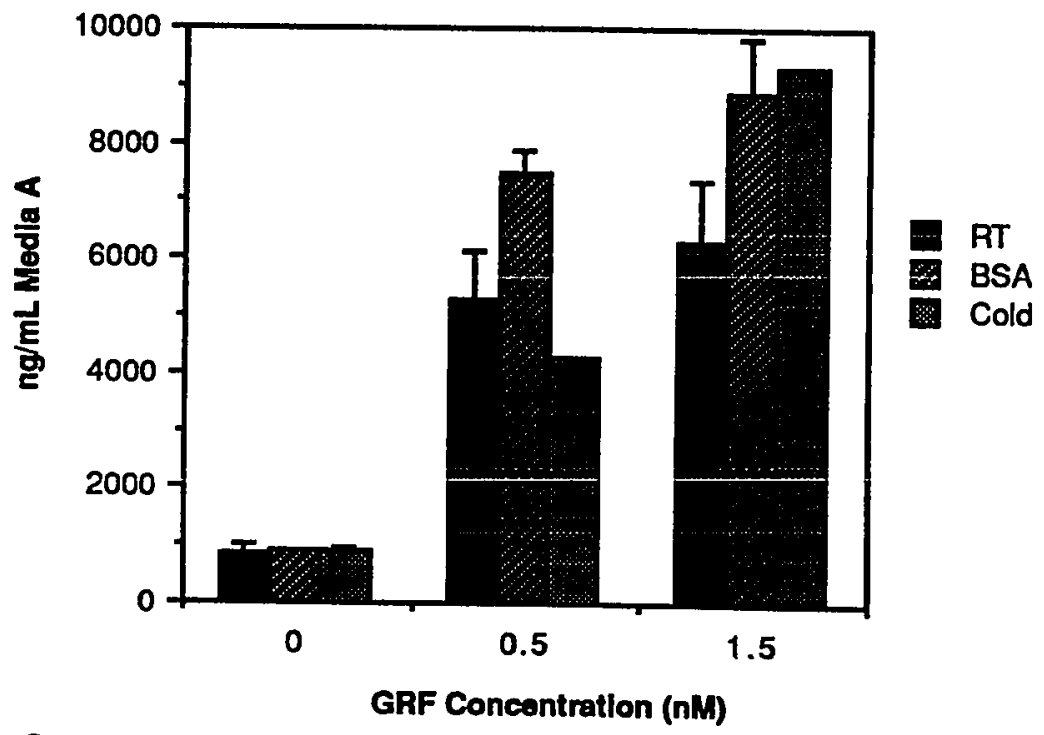

Figure 8. The effect of 45 -minute pituitary cell incubation in $1.078 \mathrm{~g} / \mathrm{mL}$ BSA on subsequent basal and rGRF-43-stimulated BGH (panel A) and IGH secretion (panel B) during a 4-hour treatment period in media $\mathrm{C}$ alone or supplemented with GRF. The data shown are for experiment $\mathrm{H1}$. Abbreviations in the figure legend are as follows; RT= cells incubated at $22-24^{\circ} \mathrm{C}, \mathrm{BSA}=$ cells incubated in $1.078 \mathrm{~g} / \mathrm{cC} \mathrm{BSA}$ at $4^{\circ} \mathrm{C}$, and Cold $=$ cells incubated at $4^{\circ} \mathrm{C}$ in MEM media. Error bars in panel A represent the $95 \%$ confidence interval for pooled media bioassayed at 4-5 rats per point. Error bars in panel $B$ represent the S.E.M. for triplicate determinations. 

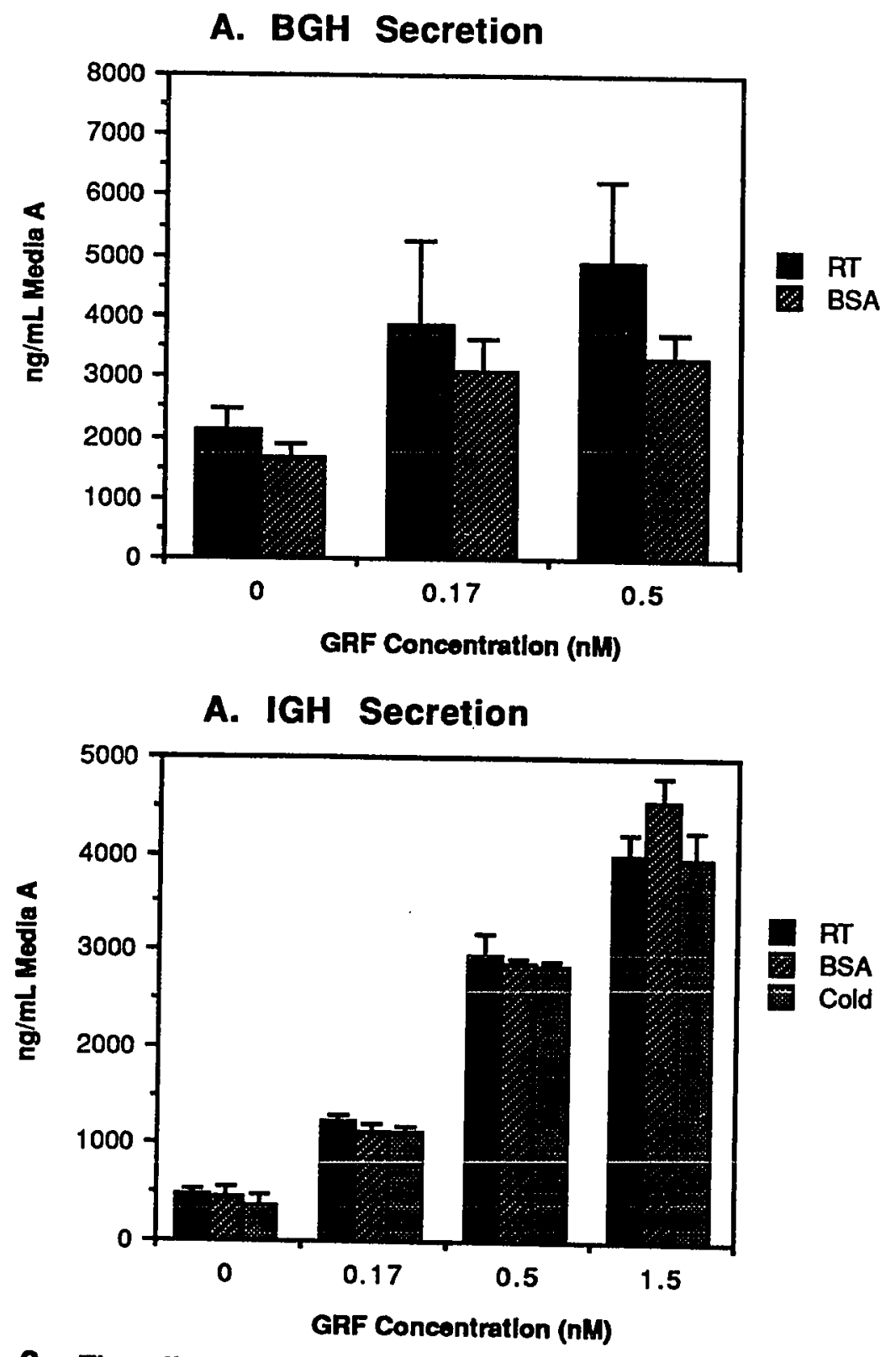

Figure 9. The effect of 45-minute pituitary cell incubation in $1.078 \mathrm{~g} / \mathrm{mL}$ BSA on subsequent basal and rGRF-43-stimulated BGH (panel A) and IGH secretion (panel B) during a 4-hour treatment period in media $C$ alone or supplemented with GRF. The data shown are for experiment $\mathrm{H} 2$. Abbreviations in the figure legend are as follows; $\mathrm{RT}=$ cells incubated at $22-24^{\circ} \mathrm{C}$, BSA = cells incubated in $1.078 \mathrm{~g} / \mathrm{cc} \mathrm{BSA}$ at $4^{\circ} \mathrm{C}$, and Cold $=$ cells incubated at $4^{\circ} \mathrm{C}$ in MEM media. Error bars in panel A represent the $95 \%$ confidence interval for pooled media bioassayed at 4-5 rats per point. Error bars in panel $B$ represent the S.E.M. for triplicate determinations. 


\section{Experiment I: Type One and Type Two Somatotroph Response}

to rGRF-43 and SRIF, Alone and in Combination

Post-dissociation cell viabilities were $93 \%, 94 \%$, and $87 \%$ for mixed, type 1 , and type 2 cells, respectively. The percentage somatotrophs were $41.3,31.6$, and $82.9 \%$, for mixed, type 1 , and type 2 cells, respectively. These values were used to express $\mathrm{GH}$ secretion on a per 1000 somatotroph basis. The results for $B G H$ and IGH secretion from the 3 cell groups are shown in Table 8 and Figure 10. Table 8 shows the actual values for IGH and BGH secretion, and the associated BGH/IGH ratio for each treatment group. Panels $A, B$, and $C$ in Figure 10 show the results for mixed, type 1, and type 2 somatotrophs, respectively. The notation for each of the seven treatment groups (Table 8, Figure 10) gives the GRF dose (nM) followed by the SRIF dose $(n M)$ for that treatment group. The control group (no GRF or SRIF) is thus represented by the term "0/0". The raw bioassay data for the SRIF treatments for mixed and type 1 cells, and the combined GRF/SRIF treatments for type 1 cells did not differ from saline-injected controls, indicating that BGH was not detectable. It should be noted that the limit of detection of rat $\mathrm{GH}$ is $1 \mu \mathrm{g}$ in the bioassay. Using this assay, failure to detect $B G H$ means that there is less than $1 \mu \mathrm{g}$ of $\mathrm{BGH}$ in the sample. Hence, this value was used to calculate the upper limit of the possible value. The actual values for these groups are thus less than or equal to the values shown. When possible, the BGH value was based on a 4-point 
multiple regression analysis using two doses of unknowns (see methods section). This analysis enabled determination of the $95 \%$ confidence interval for the actual BGH values. In several cases, however, the low dose did not differ from saline-injected controls. In these cases the high dose was used for calculations for unknowns.

In all 3 cell groups, GRF-treatment produced a dose-related increase in $\mathrm{GH}$ secretion relative to controls. The GRF-stimulated percentage increase over control GH secretion is shown in Table 9. It can be seen that in all cases, the percentage increase for BGH and IGH secretion was greatest in mixed cells, followed by type 1 cells, with the exception of IGH secretion for the $1.0 \mathrm{nM}$ treatment in type 2 cells. While the GRF-stimulated percentage increase for BGH was lowest for type 2 cells, the absolute per thousand somatotroph BGH secretion was greatest of all 3 groups for type 2 cells (Table 8). Since only 2 GRF doses were used in this experiment, estimates of ED50 and maximal dose differences between cell types cannot be made. It does appear from the data in Table 9, however, that rGRF43 has a more potent effect on $\mathrm{GH}$ secretion from type 1 somatotrophs than from type 2 somatotrophs in terms of percent increase since, with the exception of IGH secretion from $1.0 \mathrm{nM}$ GRFtreated type 2 cells, the percent increase was greater in type 1 cells than type 2 cells. Examination of the BGH/IGH ratios for GRFstimulated GH secretion from type 1 and type 2 cells (Table 8) reveals that at $0.25 \mathrm{nM}$ GRF doses, both $\mathrm{BGH}$ and IGH release increase in parallel relative to controls, since the associated $B G H / I G H$ ratios 
do not differ from controls. However, when the GRF dose is increased to $1.0 \mathrm{nM}$, type 1 somatotrophs begin to secrete more $B G H$ relative to IGH (Table 8; note increased $B G H / I G H$ ratio relative to control), and type 2 somatotrophs begin to secrete more IGH relative to $\mathrm{BGH}$ (note decreased $\mathrm{BGH} / \mathrm{IGH}$ ratio relative to control). These data suggest that the sensitivity of the 2 somatotroph types to rGRF-43 differs. While reconstruction of mixed cell GH secretion from type 1 and type 2 cell data yields poor agreement with actual mixed cell GH secretion, it can be seen from the data shown in Figure 10 that most of the mixed cell $B G H$ secretion during control and GRF-treatments is derived from the type 2 somatotroph. Mixed cell IGH secretion during control and GRF-treatments is a result of combined IGH secretion from both type 1 and type 2 somatotrophs (Figure 10).

Somatostatin treatments produced a large suppression of both $\mathrm{BGH}$ and IGH secretion from mixed and type 1 somatotrophs (Figure 10, Table 8). During these treatments, BGH secretion was actually undetectable in mixed and type 1 somatotrophs. Growth hormone secretion from somatotrophs treated with SRIF, expressed as a percent of control secretion, is shown in Table 10. In no case was BGH or IGH secretion from mixed somatotrophs greater than $41 \%$ of the appropriate control secretion. Type 2 somatotrophs responded very differently to SRIF than either mixed or type 1 somatotrophs. In Table 10 it can be seen that 0.5 and $10 \mathrm{nM}$ SRIF treatments inhibited IGH release in a dose-related fashion, to 59 and $42 \%$ of 
control secretion, respectively. In this respect, and in terms of absolute ng per thousand somatotroph IGH secretion (Table 8), type 2 somatotrophs responded to SRIF in a manner similar to mixed and type 1 somatotrophs. However, BGH secretion from type 2 somatotrophs during SRIF-treatment was $153 \%$ and $109 \%$ of control secretion for 0.5 and $10 \mathrm{nM}$ treatments, respectively (Table 10). These large values, consistent with a stimulatory effect, were not due to problems with the bioassay. Whether or not the "true" absolute ng per 1000 type 2 șomatotroph BGH secretion during SRIF treatment was as reported, it appeared that SRIF does not suppress type 2 somatotroph BGH secretion below control levels. This absence of suppression was not apparent in mixed or type 1 somatotroph BGH secretion, for which BGH was undetectable (Figure 10).

Combined GRF and SRIF treatment produced markedly different effects on the 3 cell groups (Figure 10). Table 11 shows GH secretion from the 3 cell groups in response to combined GRF and SRIF treatment, expressed as a percent of the appropriate controls. Secretion of both BGH and IGH from type 1 somatotrophs in response to $1.0 \mathrm{nM}$ GRF in combination with either $0.5 \mathrm{nM}$ SRIF or $10 \mathrm{nM}$ SRIF did not differ from SRIF treatments alone, with the exception of IGH secretion during the 1.0nM GRF / $0.5 \mathrm{nM}$ SRIF treatment. Secretion of IGH from the aforementioned group was $68 \%$ of control (Table 11) versus $40 \%$ of control for the SRIF treatment alone (Table 10), thus indicating that the presence of GRF diminished the inhibitory effect 
of SRIF. In type 2 somatotrophs combined treatment with GRF and SRIF produced a large decrease in $\mathrm{BGH}$ and IGH secretion relative to $1.0 \mathrm{nM}$ GRF treatment alone (Figure 10). However, BGH secretion was $149 \%$, and $139 \%$ of control for the $1.0 \mathrm{nM}$ GRF / $0.5 \mathrm{nM}$ SRIF, and 1.0 nM GRF / $10 \mathrm{nM}$ SRIF treatments, respectively (Table 11). Within the range of experimental error, it appears that IGH secretion was suppressed to control levels during the aforementioned treatments (Table 11). In mixed cells, the combined GRF and SRIF treatments produced effects similar to those for type 2 somatotrophs. Combined treatment with GRF and SRIF produced a large decrease in $\mathrm{BGH}$ and IGH secretion relative to $1.0 \mathrm{nM}$ GRF treatment alone (Figure 10). BGH secretion was $138 \%$, and $86 \%$ of control for the $1.0 \mathrm{nM}$ GRF / $0.5 \mathrm{nM}$ SRIF, and $1.0 \mathrm{nM}$ GRF / $10 \mathrm{nM}$ SRIF treatments, respectively (Table 11). IGH secretion was $116 \%$, and $36 \%$ of control for the 1.0 nM GRF / $0.5 \mathrm{nM}$ SRIF, and 1.0 nM GRF / $10 \mathrm{nM}$ SRIF treatments, respectively (Table 11). The effects of the combined treatments were most pronounced when the BGH/IGH ratios for secreted $\mathrm{GH}$ during combined treatments were compared to controls (Table 8). It can be seen in the table that in mixed and type 2 somatotrophs, the combined GRF/SRIF treatments cause increases in the BGH/IGH ratios for secreted hormone relative to controls. The shift in forms of $\mathrm{GH}$ released during these treatments thus favored BGH. The situation was the opposite for type 1 somatotrophs. The combined GRF/SRIF treatments caused decreases in the BGH/IGH ratio for secreted $\mathrm{GH}$ relative to controls (Table 8). Taken collectively, the 
data from Tables 8 and 11 indicate that treatment of mixed and type 2 cells with $1.0 \mathrm{nM}$ GRF and $0.5 \mathrm{nM}$ SRIF caused an increase in BGH release relative to controls, with corresponding increases in the $\mathrm{BGH} / \mathrm{IGH}$ ratio for secreted $\mathrm{GH}$. The same treatment in type 1 cells decreased $B G H$ and IGH release, and caused a decrease in the BGH/IGH ratio for secreted $\mathrm{GH}$ relative to controls. Treatment with $1.0 \mathrm{nM}$ GRF and $10 \mathrm{nM}$ SRIF diminished release of both $\mathrm{BGH}$ and IGH relative to controls in mixed and type 1 somatotrophs, though the magnitude of effect differed between cell groups (Table 11). The same treatment suppressed IGH secretion from type 2 somatotrophs to control levels, though $\mathrm{BGH}$ secretion remained increased relative to controls (Table 11).

The results of this experiment showed mainly that type 2 somatotrophs are less responsive to SRIF than type 1 somatotrophs. This observation, coupled with the high $\mathrm{BGH} / \mathrm{IGH}$ ratio for $\mathrm{GH}$ secreted from type 2 somatotrophs under basal and GRF-stimulated conditions, produced important results during combined GRF/SRIF treatments. The combined GRF/SRIF treatments suppressed IGH secretion to untreated control levels or below in all 3 cell groups, but only suppressed BGH secretion to below controls in type 1 cells. Type 2 cell BGH secretion was stimulated to above untreated controls during the combined GRF/SRIF treatments. The GRF/SRIF treatments produced an increase in the $B G H / I G H$ ratios relative to untreated controls in mixed and type 2 cells. By contrast, type 1 cell $\mathrm{BGH} / \mathrm{IGH}$ ratios were unchanged. These results showed that 
mixed cell secretion is a composite result of type 1 and type 2 cell activities. Most importantly, the results showed that the observed increases in $\mathrm{BGH}$ secretion and $\mathrm{BGH} / \mathrm{IGH}$ ratios for secreted $\mathrm{GH}$ during stress in rats could be explained by the differential effects of combinations of SRIF and GRF on the 2 populations of somatotrophs.

\section{TABLE 8}

Secretion of BGH and IGH from Mixed, Type 1, Type 2 Somatotrophs in Response to rGRF-43 and SRIF Treatment, Alone and in Combination

(values are ng per 1000 somatotrophs seeded)

\begin{tabular}{|l|l|l|l|l|l|l|l|l|l|}
\hline \multicolumn{3}{c}{ Mixed } & \multicolumn{3}{c|}{ Type 1 } & \multicolumn{3}{c|}{ Type 2 } \\
\hline Treatment* & BGH & IGH & BGH/GH & BGH & KGH & BGH/IGH & BGH & IGH & BGH/IGH \\
\hline $0 / 0$ & 14.1 & 9.92 & 1.42 & 8.07 & 6.91 & 1.17 & 40.4 & 7.80 & 5.18 \\
\hline $0.25 / 0$ & 32.7 & 30.1 & 1.09 & 12.6 & 11.7 & 1.08 & 46.0 & 8.91 & 5.16 \\
\hline $1.0 / 0$ & 75.4 & 55.3 & 1.36 & 31.3 & 18.6 & 1.68 & 86.3 & 24.6 & 3.51 \\
\hline $0 / 0.5$ & $\leq 4.72$ & 3.94 & $\leq 1.20$ & $\leq 2.57$ & 2.79 & $\leq 0.92$ & 62.2 & 4.62 & 13.5 \\
\hline $0 / 10$ & 54.72 & 4.03 & $\leq 1.17$ & $\leq 2.57$ & 2.79 & $\leq 0.92$ & 44.2 & 3.26 & 13.6 \\
\hline $1.0 / 0.5$ & 19.4 & 11.55 & 1.68 & $\leq 2.57$ & 4.71 & $\leq 0.55$ & 60.1 & 6.71 & 8.96 \\
\hline $1.0 / 10$ & 12.1 & 3.54 & 3.42 & $\leq 2.57$ & 2.94 & $\leq 0.87$ & 56.3 & 9.13 & 6.17 \\
\hline
\end{tabular}
"The notation for treatments is the GRF dose (nM), followed by the SRIF dose (nM); the
$0 / 0$ treatment thus represents the untreated control. 

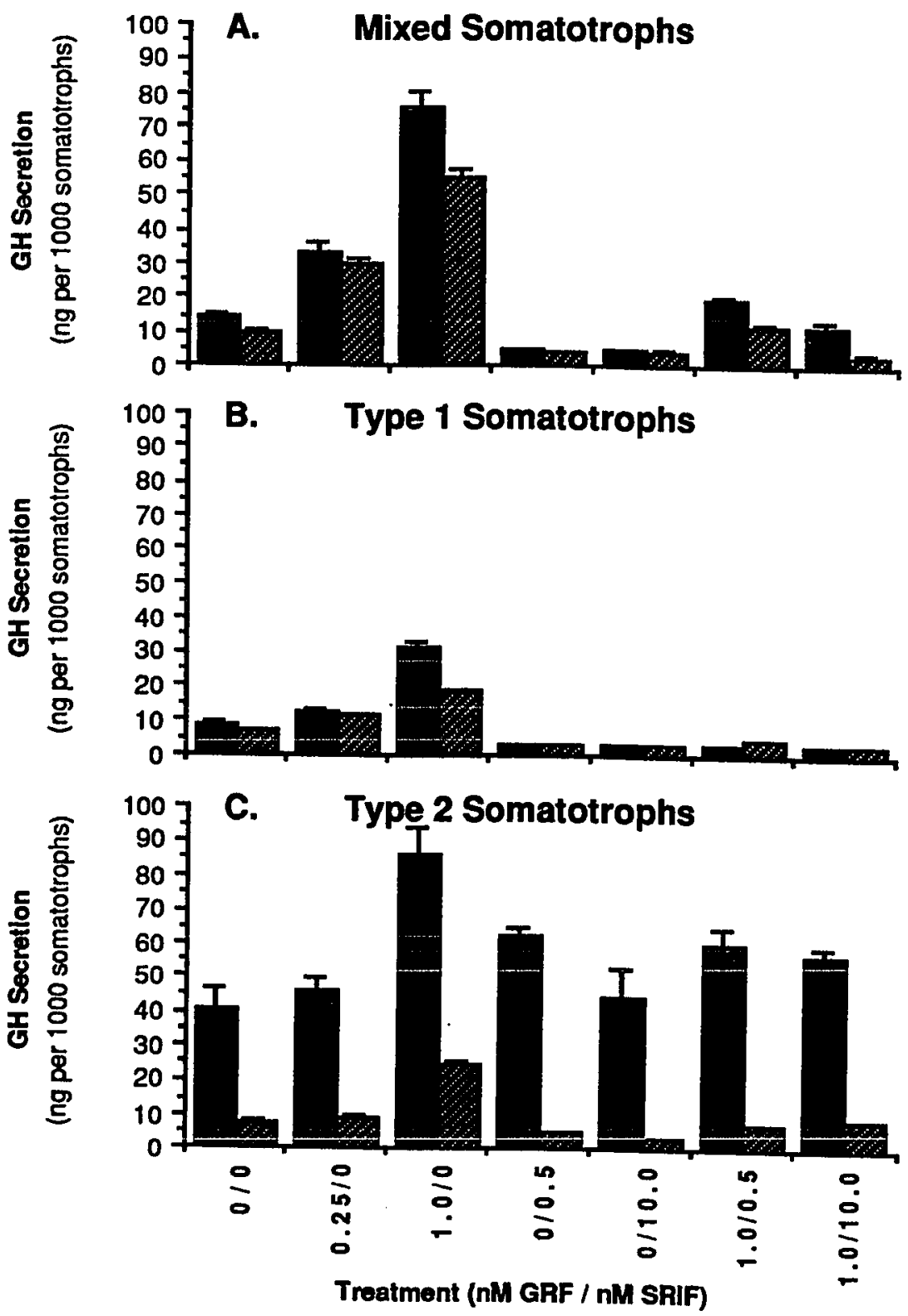

Figure 10. The effect of rGRF-43 and SRIF treatment, alone, and in combination, on secretion of BGH and IGH from mixed (panel A), type 1 (panel B), and type 2 (panel C) somatotrophs. BGH secretion is represented by the solid black bars, while IGH secretion is represented by the hatched bars. The notation for treatments gives the rGRF-43 dose (nM) followed by the SRIF dose (nM). Error bars are shown for all groups, except those where BGH was undetectable (see text). Error bars for BGH secretion represent the $95 \%$ confidence limits for single determinations in pooled media. Error bars for IGH secretion represent the S.E.M. for triplicate determinations. Several error bars are not visible, since the value was so small. 


\section{TABLE 9}

Growth Hormone Secretion from rGRF-43-Treated Somatotrophs Expressed as a Percent of Control Secretion

\begin{tabular}{lcccc} 
& \multicolumn{2}{c}{$0.25 \mathrm{nMGRE}$} & \multicolumn{2}{c}{ 1.0 nMGRE } \\
& BGH & 1GH & BGH & IGH \\
Mixed Cells & 232 & 303 & 535 & 557 \\
Type 1 Cells & 156 & 169 & 388 & 269 \\
Type 2 Cells & 114 & 114 & 214 & 315
\end{tabular}

TABLE 10

\begin{tabular}{|c|c|c|c|c|}
\hline \multirow[t]{2}{*}{$\begin{array}{r}\text { Grow } \\
\text { Somatotrop }\end{array}$} & \multicolumn{4}{|c|}{$\begin{array}{l}\text { Hormone Secretion from SRIF-Treated } \\
\text { Expressed as a Percent of Control Secretion }\end{array}$} \\
\hline & BGH & $\underline{\mathrm{IGH}}$ & BCH & IGH \\
\hline Mixed Cells & $\leq 33$ & 40 & $\leq 33$ & 41 \\
\hline Type 1 Cells & $\leq 32$ & 40 & $\leq 32$ & 40 \\
\hline Type 2 Cells & 153 & 59 & 109 & 42 \\
\hline
\end{tabular}


TABLE 11

Growth Hormone Secretion from Somatotrophs Treated with Combinations of rGRF-43 and SRIF Expressed as a Percent of Control Secretion $1.0 \mathrm{nM}$ GRF / $0.5 \mathrm{nM}$ SRIF $1.0 \mathrm{nM}$ GRF $/ 10 \mathrm{nM}$ SRIF BGH $\quad \underline{\text { IGH }}$ BGH

$\begin{array}{lllll}\text { Mixed Cells } & 138 & 116 & 86 & 36\end{array}$

$\begin{array}{llll}\text { Iype } 1 \text { Cells } & \leq 32 & 68 & \leq 32\end{array}$

$\begin{array}{lllll}\text { Iype } 2 \text { Cells } & 149 & 86 & 139 & 117\end{array}$

\section{Experiment J: Type One and Type Two Somatotroph Dose-} Response to rGRF-43 and SRIF, Alone and in Combination

Post-dissociation cell viabilities were $93 \%, 94 \%$, and $95 \%$ for mixed, type 1, and type 2 cells, respectively. The percentage somatotrophs were $40.0,31.9$, and $73.7 \%$, for mixed, type 1, and type 2 cells, respectively. These values were used to express $G H$ secretion on a per 1000 somatotroph basis. The results for BGH and IGH secretion from the 3 cell groups are shown in Table 12 and Figure 11. Table 12 shows the actual values for IGH and BGH secretion, and the associated $B G H / I G H$ ratio for each treatment group. Panels $A, B$, and $C$ in. Figure 11 show the results for mixed, type 1, and type 2 somatotrophs, respectively. The notation for each of the seven treatment groups (Table 12, Figure 11) gives the GRF dose $(n M)$ followed by the SRIF dose (nM) for that treatment group. 
The control group (no GRF or SRIF) is thus represented by the term "0/0." The raw bioassay data for the SRIF treatments for mixed and type 1 cells, and the combined GRF/SRIF treatments for type 1 cells did not differ from saline-injected controls, indicating that BGH was not detectable. Since the limit of detection of rat $\mathrm{GH}$ is $1 \mu \mathrm{g}$ in the bioassay, this value was used to calculate the upper limit of the possible value. The actual values for these groups are thus less than or equal to the values shown. When possible, the BGH value was based on a 4-point multiple regression analysis using two doses of unknowns (see Methods section). This analysis enabled determination of the $95 \%$ confidence interval for the actual BGH values. In several cases, however, the low dose did not differ from saline-injected controls. In these cases the high dose was used for calculations for unknowns.

In all 3 cell groups, GRF-treatment produced a dose-related increase in GH secretion relative to controls. The GRF-stimulated percentage increase over control GH secretion is shown in Table 13. The GRF-stimulated percentage increase over control BGH and $1 G H$ secretion varied across cell groups, without a definite pattern. However, type 2 somatotrophs appeared to be more responsive to GRF in terms of IGH secretion than type 1 somatotrophs (compare type 2 cell IGH values with type 1 cell IGH values in Table 13). Note that in all cases the mixed cell percent increase over control secretion was intermediate between the type 1 and type 2 cell values. It should be noted that while the $0.25 \mathrm{nM}$ GRF-stimulated 
percentage increase for $\mathrm{BGH}$ was lowest for type 2 cells, the absolute per thousand somatotroph BGH secretion was greatest of all 3 groups for type 2 cells (Table 12). Since only 2 GRF doses were used in this experiment, estimates of ED50 and maximal dose differences between cell types cannot be made. Examination of the BGH/IGH ratios for GRF-stimulated $\mathrm{GH}$ secretion from type 1 cells (Table 12) reveals that at either the 0.25 or $1.0 \mathrm{nM}$ GRF doses, both $\mathrm{BGH}$ and IGH release increases in parallel relative to controls, since the associated $\mathrm{BGH} / \mathrm{IGH}$ ratios do not differ from controls. In type 2 cells, however, the BGH/IGH ratios decreased by over $40 \%$ with GRF treatment (Table 12). These data indicate that the sensitivity of the 2 somatotroph types to rGRF-43 differs. While reconstruction of mixed cell GH secretion from type 1 and type 2 cell data yields poor agreement with actual mixed cell GH secretion, it can be seen from the data shown in Figure 11 that most of the mixed cell BGH secretion during control and GRF-treatments is derived from the type 2 somatotroph. Mixed cell IGH secretion during control and GRF-treatments is a result of combined IGH secretion from both type 1 and type 2 somatotrophs (Figure 11).

Growth hormone secretion from somatotrophs treated with SRIF, expressed as a percent of control secretion, is shown in Table 14. Somatostatin treatment suppressed secretion of both BGH and IGH by $52 \%$ or greater from mixed and type 1 somatotrophs (Figure 11, Table 12, Table 14). Type 2 somatotrophs responded differently to SRIF than either mixed or type 1 somatotrophs. In Table 14 it can 
be seen that 0.5 and $10 \mathrm{nM}$ SRIF treatments inhibited type 2 somatotroph IGH release to 47 and $45 \%$ of control secretion, respectively. In this respect, and in terms of absolute ng per thousand somatotroph IGH secretion (Table 12), type 2 somatotrophs responded to SRIF in a manner similar to mixed and type 1

somatotrophs. However, BGH secretion from type 2 somatotrophs during SRIF-treatment was $61 \%$ and $64 \%$ of control secretion for 0.5 and $10 \mathrm{nM}$ treatments, respectively (Table 14). These values were considerably greater than those for type 1 cells (for which BGH was undetectable), suggesting that type 2 cells are less responsive to SRIF than are type 1 cells. This lower responsiveness of type 2 cells to SRIF seemed apparent in the corresponding values for mixed cells (Table 14; note that, with the exception of IGH secretion from $10 \mathrm{nM}$ SRIF-treated mixed cells, mixed cell values are intermediate between type 1 and type 2 cell values). These conclusions are strengthened by the fact that BGH was undetectable during SRIF treatments of mixed somatotrophs.

Combined GRF and SRIF treatment produced markedly different effects on the 3 cell groups (Figure 11). Table 15 shows GH secretion from the 3 cell groups in response to combined GRF and SRIF treatment, expressed as a percent of the appropriate controls. Secretion of both BGH and IGH from type 1 somatotrophs in response to $1.0 \mathrm{nM}$ GRF in combination with either $0.5 \mathrm{nM}$ SRIF or $10 \mathrm{nM}$ SRIF did not differ from SRIF treatments alone, with the exception of IGH secretion during the $1.0 \mathrm{nM}$ GRF / $0.5 \mathrm{nM}$ SRIF treatment. Secretion 
of IGH from the aforementioned group was $230 \%$ of control (Table 15) versus $24 \%$ of control for the SRIF treatment alone (Table 14), thus indicating that the stimulatory effect of GRF dominated over the inhibitory effect of SRIF. With the higher SRIF dose (1.0 nM GRF ( $10 \mathrm{nM}$ SRIF), the GRF stimulatory effect on IGH was almost completely overridden by the SRIF inhibitory effect (compare Table 15 vs Table $14 ; 46 \%$ vs 38\%). In type 2 somatotrophs, combined treatment with GRF and SRIF produced a large decrease in BGH and IGH secretion relative to $1.0 \mathrm{nM}$ GRF treatment alone (Figure 11). However, BGH secretion was $107 \%$, and $96 \%$ of control for the $1.0 \mathrm{nM}$ GRF / $0.5 \mathrm{nM}$ SRIF, and $1.0 \mathrm{nM}$ GRF / $10 \mathrm{nM}$ SRIF treatments, respectively (Table 15). Type 2 cell IGH secretion was stimulated to $472 \%$ and $136 \%$ above control levels during the aforementioned respective treatments (Table 15), but to a considerably lesser extent than with $1.0 \mathrm{nM}$ GRF alone (Table 13; $1034 \%$ of control for $1.0 \mathrm{nM}$ GRF alone). In mixed cells, the combined GRF and SRIF treatments produced effects similar to those for type 2 somatotrophs. Combined treatment with GRF and SRIF produced a large decrease in $\mathrm{BGH}$ and $\mathrm{IGH}$ secretion relative to $1.0 \mathrm{nM}$ GRF treatment alone (Figure 11). BGH secretion was $349 \%$, and $93 \%$ of control for the $1.0 \mathrm{nM}$ GRF / $0.5 \mathrm{nM}$ SRIF, and $1.0 \mathrm{nM}$ GRF / $10 \mathrm{nM}$ SRIF treatments, respectively (Table 15). IGH secretion was $294 \%$, and $52 \%$ of control for the $1.0 \mathrm{nM}$ GRF / $0.5 \mathrm{nM}$ SRIF, and $1.0 \mathrm{nM}$ GRF / 10 nM SRIF treatments, respectively (Table 15). The effects of the combined treatments were most apparent when the BGH/IGH ratios 
for secreted $\mathrm{GH}$ during combined treatments were compared to controls (Table 12). It can be seen in the table that in mixed somatotrophs, the combined GRF/SRIF treatments caused increases in the $B G H / I G H$ ratios for secreted hormone relative to controls. The shift in forms of $\mathrm{GH}$ released during these treatments thus favored $B G H$. The situation was the opposite for type 1 somatotrophs. The combined GRF/SRIF treatments caused decreases in the BGH/IGH ratio for secreted $\mathrm{GH}$ relative to controls (Table 12). In fact $\mathrm{BGH}$ was not detectable in type 1 somatotrophs during these treatments. For type 2 cells the combined GRF/SRIF treatments caused decreases in the BGH/IGH ratio for secreted $\mathrm{GH}$ relative to controls (Table 12). It is important to note, however, that during these treatments type 2 cells continued to secrete predominantly $B G H$, yielding $B G H / I G H$ ratios of 1.7 and 5.4 for the $1.0 \mathrm{nM}$ GRF / $0.5 \mathrm{nM}$ SRIF, and 1.0 nM GRF / $10 \mathrm{nM}$ SRIF treatments, respectively (Table 12). During these treatments it is evident that the mixed cell $B G H / I G H$ values are a result of the combined activities of the type 1 and type 2 somatotrophs of which they are composed. Taken collectively, the data from Tables 12 and 15 indicate that treatment of mixed cells with combined 1.0 nM GRF / 0.5 nM SRIF caused an increase in BGH release relative to controls, with corresponding increases in the $\mathrm{BGH} / \mathrm{IGH}$ ratio for secreted $\mathrm{GH}$. For type 2 cells the aforementioned treatment decreased the $\mathrm{BGH} / \mathrm{IGH}$ ratio, mainly due to increased IGH secretion in response to the treatment. The same treatment in type 1 cells decreased BGH but not IGH release, and caused a decrease in 
the $\mathrm{BGH} / \mathrm{IGH}$ ratio for secreted $\mathrm{GH}$ relative to controls. Treatment with combined 1.0 nM GRF / $10 \mathrm{nM}$ SRIF diminished release of both $\mathrm{BGH}$ and IGH relative to controls in mixed and type 1 somatotrophs, though the magnitude of effect differed between cell group (Table 15). The same treatment suppressed BGH secretion from type 2 somatotrophs to control levels, though IGH secretion remained increased relative to controls (Table 15).

The results of this experiment showed mainly that type 2 somatotrophs are less responsive to SRIF than type 1 somatotrophs. This observation, coupled with the high $\mathrm{BGH} / \mathrm{IGH}$ ratio for $\mathrm{GH}$ secreted from type 2 somatotrophs under basal and GRF-stimulated conditions, produced important results during combined GRF/SRIF treatments. Type 2 cell BGH secretion was stimulated to above untreated controls during the combined GRF/SRIF treatments. The GRF/SRIF treatments produced an increase in the $\mathrm{BGH} / \mathrm{IGH}$ ratios relative to untreated controls in mixed and type 2 cells. By contrast, type 1 cell BGH/IGH ratios were unchanged. These results showed that mixed cell secretion is a composite result of type 1 and type 2 cell activities. Most importantly, the results showed that the observed increases in BGH secretion and BGH/IGH ratios for secreted $\mathrm{GH}$ during stress in rats could be explained by the differential effects of combinations of SRIF and GRF on the 2 populations of somatotrophs. 


\section{TABLE 12}

\section{Secretion of BGH and IGH from Mixed, Type 1, and Type 2 Somatotrophs in Response to rGRF-43 and SRIF Treatment, Alone and in Combination}

(values are ng per 1000 somatotrophs seeded)

\begin{tabular}{|l||l|l|l|l|l|l|l|l|l|}
\hline \multicolumn{3}{c|}{ Mixed } & \multicolumn{3}{c|}{ Type 1 } & \multicolumn{3}{c|}{ Type 2 } \\
\hline Treatment* & BGH & IGH & BGH/IGH & BGH & IGH & BGH/IGH & BGH & IGH & BGH/IGH \\
\hline \hline $0 / 0$ & 36.6 & 10.3 & 3.6 & 11.5 & 11.7 & 1.0 & 86.0 & 11.2 & 7.7 \\
\hline $0.25 / 0$ & 97.0 & 42.1 & 2.3 & 33.5 & 28.1 & 1.2 & 204.6 & 49.0 & 4.2 \\
\hline $1.0 / 0$ & 204.9 & 73.4 & 2.8 & 59.9 & 62.1 & 1.0 & 531.9 & 115.7 & 4.6 \\
\hline $0 / 0.5$ & $\leq 17.6$ & 3.3 & $\leq 5.3$ & 54.3 & 2.8 & $\leq 1.5$ & 52.4 & 5.3 & 10.0 \\
\hline $0 / 10$ & $\leq 15.2$ & 2.9 & $\leq 5.2$ & $\leq 4.3$ & 4.5 & $\leq 1.0$ & 54.8 & 5.0 & 11.0 \\
\hline $1.0 / 0.5$ & 127.6 & 30.2 & 4.2 & $\leq 4.3$ & 26.8 & $\leq 0.2$ & 91.9 & 52.7 & 1.7 \\
\hline $1.0 / 10$ & 33.9 & 5.4 & 6.3 & $\leq 4.3$ & 5.3 & 50.8 & 82.2 & 15.3 & 5.4 \\
\hline
\end{tabular}

"The notation for treatments is the GRF dose (nM), followed by the SRIF dose (nM); the $0 / 0$ treatment thus represents the untreated control. 

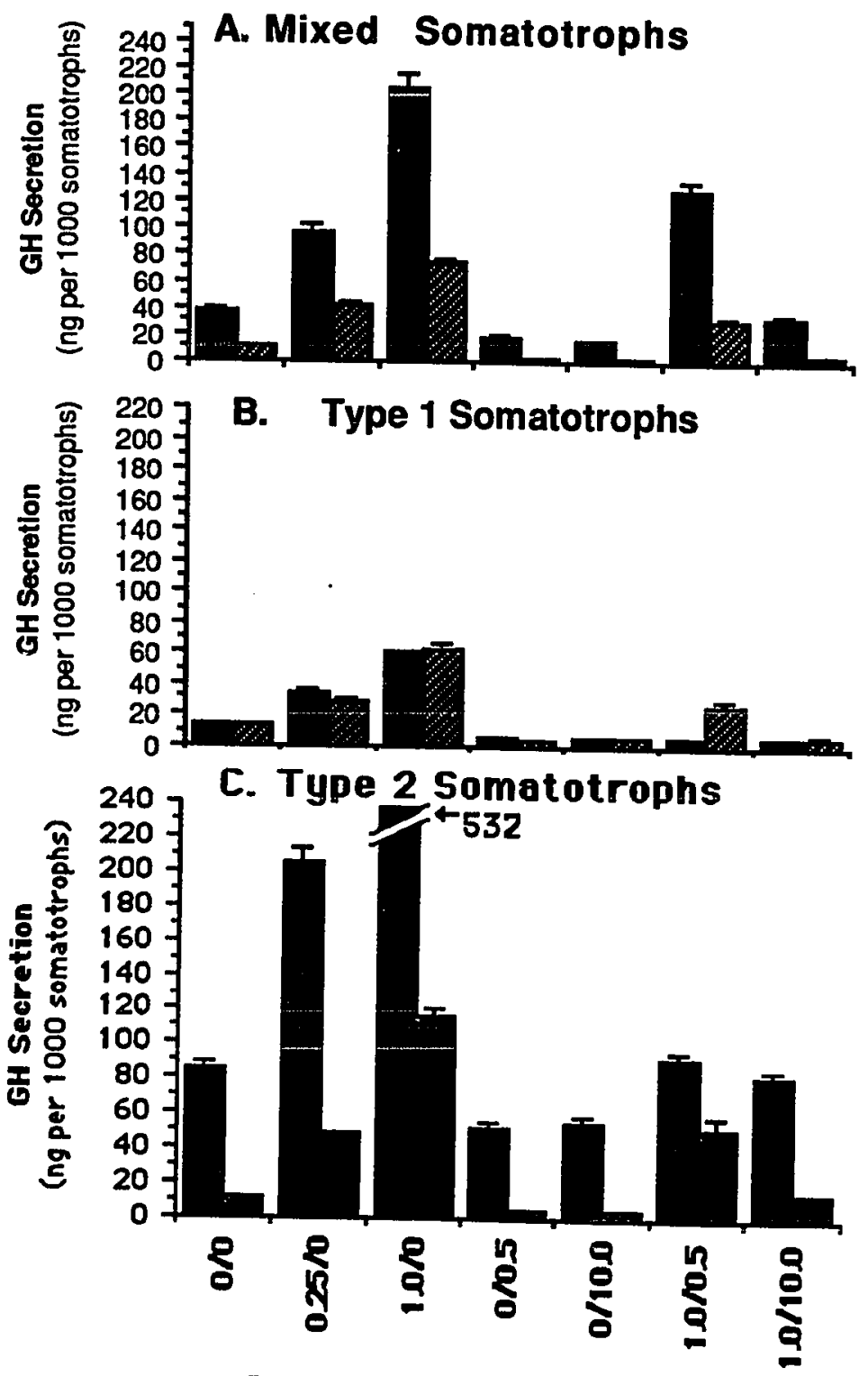

Treatment (nM GRF/ nM SRIF)

Figure 11. The effect of rGRF-43 and SRIF treatment, alone, and in combination, on secretion of BGH and IGH from mixed (panel A), type 1 (panel B), and type 2 (panel C) somatotrophs. BGH secretion is represented by the solid black bars, while IGH secretion is represented by the hatched bars. The notation for treatments gives the rGRF-43 dose (nM) followed by the SRIF dose (nM). Error bars are shown for all groups, except those where BGH was undetectable (see text). Error bars for BGH secretion represent the $95 \%$ confidence limits for single determinations in pooled media. Error bars for IGH secretion represent the S.E.M. for triplicate determinations. Several error bars are not visible, since the value was so small. 


\section{TABLE 13}

Growth Hormone Secretion from rGRF-43-Treated Somatotrophs Expressed as a Percent of Control Secretion

\begin{tabular}{lcccc} 
& \multicolumn{2}{c}{$0.25 \mathrm{nMGRE}$} & \multicolumn{2}{c}{ 1.0 nM GRE } \\
& BGH & IGH & BGH & IGH \\
Mixed Cells & 265 & 409 & 560 & 713 \\
Iype 1Cells & 291 & 240 & 521 & 531 \\
Iype 2 Cells & 238 & 438 & 618 & 1034
\end{tabular}

\section{TABLE 14}

Growth Hormone Secretion from SRIF-Treated Somatotrophs Expressed as a Percent of Control Secretion

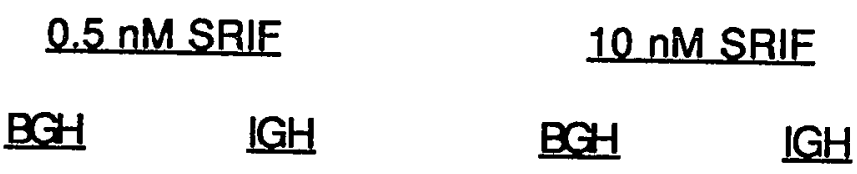

$\begin{array}{lllll}\text { Mixed Cells } & \leq 48 & 32 & \leq 42 & 28\end{array}$

$\begin{array}{lllll}\text { Type } 1 \text { Cells } & \leq 37 & 24 & \leq 37\end{array}$

$\begin{array}{lllll}\text { Type 2 Cells } & 61 & 47 & 64 & 45\end{array}$ 


\section{TABLE 15}

Growth Hormone Secretion from Somatotrophs Treated with Combinations of rGRF-43 and SRIF Expressed as a Percent of Control Secretion

$1.0 \mathrm{nM}$ GRF $/ 0.5 \mathrm{nM}$ SRIF $1.0 \mathrm{nM}$ GRF $/ 10 \mathrm{nM}$ SRIF

$\begin{array}{lcccc} & \text { BGH } & \text { IGH } & \text { BGH } & \text { IGH } \\ \text { Mixed Cells } & 349 & 293 & 93 & 52 \\ \text { Type 1 Cells } & \leq 37 & 229 & \leq 37 & 45 \\ \text { Type 2 Cells } & 107 & 470 & 96 & 137\end{array}$




\section{Discussion}

The results for experiment $A$ suggest that the $B G H$ secretion in response to hpGRF-40 in mixed cells differs from IGH secretion. Maximal GRF-stimulated IGH secretion occurred at $1.56 \mathrm{nM}$, while BGH secretion appeared to have not yet reached maximum at $400 \mathrm{nM}$. Moreover, at the full range of GRF doses, from $0 \mathrm{nM}$ to $400 \mathrm{nM}$, the $\mathrm{BGH} / \mathrm{IGH}$ ratio ranged from 2.5 to 8.5 , indicating that at doses $\mathrm{BGH}$ was the predominant form of $\mathrm{GH}$ released into the media.

Treatment with hpGRF -40 produced a maximal 9-times increase in $\mathrm{BGH}$ secretion at $400 \mathrm{nM}$, while the maximal increase in IGH release was 3.6-times at $1.56 \mathrm{nM}$. These results for IGH maximal secretion and ED50 are in agreement with previous reports for hpGRF-40 $[13,18,79]$. The maximal $B G H$ increase is difficult to interpret due to the biphasic nature of the $\mathrm{BGH}$ dose-response. There were two linear regions in the $\mathrm{BGH}$ dose-response curve; one in the dose range of 0 to $6.25 \mathrm{nM}$, and another in the 25 to $400 \mathrm{nM}$ range. The biphasic curve in the mixed cell population could represent a combination of heterogeneous responses in type 1 and type 2 somatotroph populations. Alternately, it could be due to the presence of some impurity(-ies) in the GRF preparation, since the preparation used was not purified to homogeneity. Whatever the source of the biphasic response, mixed somatotroph populations clearly have different BGH and IGH dose-response curves to hpGRF-40, and at all doses BGH secretion is greater than IGH secretion. 
If one interprets the $6.25 \mathrm{nM}$ dose as the maximal dose for $\mathrm{BGH}$ secretion then the ED50 can be calculated from the regression equation to be $0.77 \mathrm{nM}$. This interpretation seems unwarranted, however, given the 2-times increase in BGH secretion at the $400 \mathrm{nM}$ dose relative to the $6.25 \mathrm{nM}$ dose. This is in contrast to the approximate BGH ED50 of $6.25 \mathrm{nM}$ for the complete dose-response curve. Whichever value is considered, both differ considerably from the approximate IGH ED50 of $0.25 \mathrm{nM}$. The differences in maximal dose and ED50 between BGH and IGH explain the progressive increase in the $B G H / I G H$ ratio with increasing GRF doses. It is difficult to interpret the physiological significance of the heterogeneity in the $B G H$ and IGH response to hpGRF-40. Originally, it was thought that since BGH can be selectively released in vivo (see Introduction: $\mathrm{GH}$ Release During Stress, Hypoglycemia, and Spaceflight), there might be more than one releasing factor, with each GRF controlling release of each form of GH. While the possibility of an additional GRF cannot be eliminated on the basis of these experiments, its existence seems improbable and is not necessary to explain in vivo results. It also seems improbable that hpGRF-40, or presumably rGRF-43 (which bears $70 \%$ sequence homology to hGRF40) can alone account for selective BGH release under stress conditions in rats. The effect of GRF could be modulated by SRIF or some other factor(s) acting directly on the somatrophs to modify their response. For example, the recently discovered 29-amino acid brain/gut peptide, galanin, stimulates IGH secretion in vivo, but not in vitro [69] suggesting 
that GRF/SRIF release can be modulated by galanin. It is possible that varying concentration ratios of hypothalamic factors differentially regulate the two somatotroph populations, resulting in selective BGH versus IGH release. Due to the heterogeneous BGH and IGH dose-response curves to hpGRF-40, it was decided that further investigation of the $\mathrm{GH}$ secretory response using purified rGRF-43 and mixed, type 1, and type 2 cells should be performed (experiment $G$, below). The 4-hour GRF-treatment in experiment $A$ produced a profound dose-related increase in IGH "production" (Table 2). The effect was maximal at the $1.56 \mathrm{nM}$ dose, which parallels the data for IGH secretion. It is noteworthy that the maximal IGH production during the 4-hour treatment (Table 1) was slightly greater than the initial intracellular IGH (6.48 $\mathrm{ng} / 1000$ cells). The increased synthesis is due to increased transcription and translation since it has been shown that hpGRF-40 [17] and hpGRF-44 [31] increase GH messenger RNA in cultures of rat pituitary cells.

One of the main purposes of this thesis research was to determine differences between BGH and IGH secretion in response to GRF exposure in various somatotroph types. As mentioned previously, Bilezikjian and Vale [9] have determined that both basal and GRFstimulated IGH secretion is linear over the 4-hour treatment period. One aspect of the experimental conditions which was not evaluated critically was use of 3 to 4-day preculture periods prior to treatment with secretagogues (e.g., GRF). Experiment B was designed to make this evaluation. In general, increasing duration of preculture resulted 
in a decline in both basal and GRF-stimulated BGH and IGH secretion. As indicated in the results section for experiment B1 (Figure 2) and for experiment B2 (Figure 3), there were some exceptions to the aforementioned statement. However, it can be seen that with the exception of the $20 \mathrm{nM}$ treatment in Figure $2 \mathrm{~A}$, secretion of $\mathrm{BGH}$ and IGH from the 4-day preculture groups was reduced relative to the 0 day preculture groups. Secretion from 4-day preculture groups expressed as a percent of 0-days preculture groups, ranged from 18 to $53 \%$. Based on these data, preculture was eliminated in all subsequent experiments (i.e., $\mathrm{H}, \mathrm{I}$, and $\mathrm{J}$ ). The discrepancies between BGH secretion in experiment B1 and B2 are difficult to explain, considering the relatively good agreement between IGH results. The bioassay rats for these experiments were supplied by Charles River Labs. This was the first time that this supplier had been used in Dr. R.E. Grindeland's laboratory. Several rats died over the course of the assay. These facts may contribute to the discrepancies. Doserelated increases in BGH and IGH secretion were observed in experiment $B$. It appears that $B G H$ secretion was not yet maximal at $20 \mathrm{nM}$ GRF and that IGH secretion was maximal by $5 \mathrm{nM}$. These results are consistent with those of experiment $A$, which also used hpGRF-40.

One aspect of the culture conditions employed in experiment $B$ left some uncertainty. The cells were incubated in a closed culture system, which prevented gaseous exchange with the atmosphere. Choice of this procedure was based on unpublished observations by W. Hymer. Hymer found that 9-day IGH secretion from dispersed 
pituitary cells incubated in sealed $4.8 \mathrm{~mL}$ glass vials containing 4.0 $\mathrm{mL}$ of media plus cells and $0.8 \mathrm{~mL}$ of air, did not differ from secretion from cells incubated under "open-system" conditions, with constant exposure to humidified $95 \%$ air $/ 5 \% \mathrm{CO}_{2}$. No differences between culture systems were found at all cell concentrations tested (1-, 10-, 50-, 100-, and 200-thousand per vial). Saturation of culture media with $\mathrm{O}_{2}$ prior to incubation in closed vials also produce no measurable differences. Given these results, Dr. Hymer advised the use of "open system" culture conditions for future experiments. It was also advised that the effects of "closed system" incubation under the conditions employed in experiment $B$ be evaluated.

Experiment $C$ investigated the effects of closed culture flasks filled with air only (C/A), closed culture flasks filled with $95 \%$ air I $5 \% \mathrm{CO}_{2}(\mathrm{C} / \mathrm{C})$, and open culture flasks exposed continuously to $95 \%$ air / $5 \% \mathrm{CO}_{2}$ in a humidified incubator $(\mathrm{O} / \mathrm{C})$ on basal and GRFstimulated IGH secretion. As can be seen in Figure 4A, there were no apparent effects of the 3 culture conditions on release of IGH into media after 2 and 4 days culture. Similarly, in Figure 4B, it can be seen that after 2 days culture there were no apparent differences in IGH secretion among the 3 groups in response to 4-hour treatment with $5 \mathrm{nM}$ hpGRF-40. After 4 days of preculture there was an average $18 \%$ decline in $5 \mathrm{nM}$ hpGRF-40 stimulated IGH release, the decrease being slightly more than $18 \%$ for closed culture conditions, and slightly less for the open culture condition. The difference 
between the closed and open culture conditions at 4 days (Figure 4B) suggests that the culture conditions might have some slight effect on GRF-stimulated IGH secretion. The effect, however, does not compare to the large decreases seen with increasing preculture duration in experiment B. Moreover, temporally related decreases in $5 \mathrm{nM}$ GRF-stimulated IGH secretion were observed in the open culture condition as well, further indicating that the results from experiment $B$ were valid. The decrease in $5 \mathrm{nM}$ GRF-stimulated IGH secretion in Figure 4B was interpreted as a partial replication of the results from experiment $B$.

The results of experiment $D$ indicated that pituitary-derived 191 amino acid human GH is stable for at least four days when cultured in the presence of mixed rat somatotrophs. Additionally, the data indicated that human GH does not exert a negative feedback effect on rat IGH secretion over a four-day culture period. Moreover, the data suggested that rat $\mathrm{GH}$ secreted into media does not exert a negative feedback effect on rat IGH secretion, since rat IGH secretion was highly linear with respect to time in cells cultured in media alone or supplemented with human GH (see regression equations and correlation coefficients). One might question whether the observed lack of hGH degradation over the four-day culture period could have been due to species differences in the enzymes involved in degrading $\mathrm{GH}$. While this is a possible explanation for the observed results, it seems more likely that secreted $\mathrm{GH}$ is degraded by relatively non-specific proteases, perhaps released into 
media from dying cells. Barring the possible aforementioned alternate explanation, it therefore appears that with the culture conditions used in these thesis experiments that negative feedback of secreted IGH is not an important factor in explaining results.

The experiments discussed to this point (A-C) served as controls to validate the procedures employed herein. Before the primary experiments could be conducted, however, validation of the cell separation procedure was required. Hymer has employed two methods for separation of somatotrophs [45]. The method most frequently employed utilizes a 2-density discontinuous gradient system, as previously described. An alternate method uses a single BSA density (concentration $1.071 \mathrm{~g} / \mathrm{mL}$ ), with cells applied directly above this solution prior to centrifugation. Originally it was thought that this was the best method for cell separation. Experiment $E$ investigated the functional differences in type 1 and type 2 somatotrophs separated by the latter method. The results (Table 3) were in agreement with the data reported by Grindeland and Hymer (36). Type 2 cells released about 2.3-times more BGH, and 2.4-times less IGH over the 12-day culture period. Twelve-day $\mathrm{BGH}$ and IGH secretion from mixed cells was intermediate between the values for type 1 and type 2 cells. At each of the 4-day culture intervals, the BGH/IGH ratio for $\mathrm{GH}$ secreted from type 2 cells was 6 to 28-times greater than the corresponding ratio for type 1 cells. Complete results are shown in Table 3 , but emphasis will be placed on secretion during days $0-4$, since 1 ) this period most closely 
approximates in vivo physiology; 2) numerous biochemical changes (including cell death) can occur over a 12-day culture period; and 3) the main experiments in this thesis (experiments $G$ through I) all involve cultures which end within 16 hours following termination of pituitary donors. During the 0-4 day culture period, type 2 cells secreted 1.8-times greater BGH and $\mathrm{iGH}$ than did mixed cells. By contrast, type 1 cells secreted 5.4-times less BGH and 2.3-times greater IGH than mixed cells. From these data it can be deduced that type 1 cells secreted primarily $I G H$, and type 2 somatotrophs secreted primarily BGH. This relationship holds true even when secretion is estimated on a per somatotroph basis (type $1 \approx 15 \%$, and type $2 \approx 80 \%$ somatotrophs). Actual per somatotroph secretion could not be calculated, as the immunocytochemistry procedure failed for this experiment. The results indicate that cell separation was successful, and they essentially replicate the data of Grindeland and Hymer [36].

The single density cell separation system appears to replicate results obtained using the 2-density system, but only a few experiments have been done. For this reason the 2-density separation method was employed in experiment $F$ to validate the cell separation procedure to be used in experiments $G, H$, and $\mathrm{I}$. Over the course of the twelve-day culture, mixed cell and type 1 cell viabilities were within $71-89 \%$ at each determination. While $71 \%$ is lower than desired for this system, it was considered acceptable to provide valid data. However, type 2 cell viability was about $43 \%$ 
post-dissociation and $11 \%$ following the 12-day culture. More will be said about the issue of viability below. The results of experiment $F$, a 12-day culture of separated cells obtained with the 2-phase method, are summarized in Table 4 and 5 . Table 4 shows the results expressed on a per thousand cells seeded basis, while Table 5 shows the results on a per thousand somatotrophs basis. By comparing results from Table 4 with those from Table 5 an interesting point can be deduced. If a comparison of secretion rates for BGH and IGH is made between cell types, then the data in Table 4 leads one to believe that, over the 12 day culture period, type 2 cells secrete 7.5-times greater BGH and 3-times less IGH than type 1 cells. However, to describe accurate functional differences between somatotroph types, data must be compared on a per somatotroph basis. The data in Table 4 are included for completeness, and because prior to use of the immunocytochemistry procedure to quantitate numbers of cell types, results were expressed on a per thousand cells "seeded" basis [36]. As with experiment $E$, the experimerit $F$ discussion focuses on $\mathrm{GH}$ secretion during days $0-4$, for the reasons mentioned above. It should be noted (Table 4) that 12-day type 2 cell BGH secretion was 4.5-times greater, and IGH secretion 1.3-times less than in mixed cells. By contrast, type 1 $\mathrm{BGH}$ secretion was 1.7-times less, and IGH secretion was 2.4-times greater than in mixed cells. These results, as well as those for 4day secretion (Table 4), are in good agreement with the results from experiment $E$ (Table 3) qualitatively, if not quantitatively. It is a 
truism of cell culture that absolute levels of secretion do not reproduce well - even with aliquots of the same cells. However, with replicate experiments, the pattern of secretion is usually preserved. When expressed on a per thousand somatotroph basis (Table 5) the differences between cell types seen in Table 4 are repeated, though in all cases the magnitude of the difference is reduced. A reason for the diminution of differences is that type 1 cells were $17.4 \%$, while type 2 cells were $77.6 \%$ somatotrophs. When the secretory activity of type 1 and type 2 cells are compared on a per thousand somatotroph basis the "true" functional differences become apparent. Over the 12-day culture, type 2 somatotrophs secreted 1.7-times more $\mathrm{BGH}$ than type 1 somatotrophs. It is not clear why mixed cells secreted less BGH than type 1 cells (Table 5), as this has not been observed before. It could be due to an error in cell counting. Over the 12-day culture period, type 1 somatotrophs secreted 9.9-times greater IGH than did type 2 somatotrophs (Table 5). Mixed cell IGH secretion was intermediate between that for type 1 and type 2 cells. The 12-day $\mathrm{BGH} / \mathrm{IGH}$ activity ratios for media from mixed (BGH/IGH=3.4), type 1 $(B G H / I G H=1.0)$, and type 2 cells $(B G H / I G H=16)$ were in agreement with data from previous work by Grindeland and Hymer [36]. The pattern of BGH and IGH secretion for the 3 groups over the 3 successive 4-day intervals was interesting, but emphasis will be placed on 0 to 4-day secretion since it is this interval which is most relevant to the objectives of this thesis. In the 0 to 4-day 
culture interval type 2 somatotrophs secreted 3-times greater BGH and 6-times less IGH than did type 1 somatotrophs. The BGH/IGH activity ratio was 20 for type 2 somatotrophs and 1.1 for type 1 somatotrophs. It can thus be seen that type 2 somatotrophs released primarily BGH. While it cannot be said, on the basis of these data, that type 1 somatotrophs release primarily IGH, it seems probable that most ${ }^{1}$ of the circulating IGH comes from type 1 somatotrophs. ldeally, one would expect that the results from type 1 and type 2 somatotrophs could be used to predict mixed somatotroph BGH and IGH secretion, particulary if there were no cell-cell paracrine interactions. If, for the sake of simplicity, one assumes that type 1 and type 2 somatotrophs each represent $50 \%$ of the total somatotrophs, then the simple average of $\mathrm{BGH}$ and IGH secretion for type 1 and type 2 somatotrophs should yield a value similar to that for mixed somatotrophs. Inspection of the values in Table 5 indicate that in most cases, the averaged values exceed the mixed cell values by several-times. Perhaps the separation procedure disrupts some paracrine communication between pituitary cells. The cause of the discrepancy is unknown, but has also been observed by Hymer (personal communication, 1987). For this reason the BGH/IGH ratio appears to be a better index for comparison between cell groups. As described above, the BGH/IGH ratios for mixed, type 1, and type 2

\footnotetext{
$186 \%$ on the basis of these data, assuming $50 \%$ type 1 somatotrophs in vivo. While this calculation does not include the effects of GRF or SRIF it demonstrates the differences between somatotroph types.
} 
cells were in agreement with the work of Grindeland and Hymer [36]. BGH production in type 2 somatotrophs over the 12-day culture was 2.6-times greater than mixed somatotrophs, and 1.7-times greater than type 1 somatotrophs. By contrast, IGH production in type 2 somatotrophs was 6.1-times less than mixed somatotrophs and 14times less than in type 1 somatotrophs. It can be seen from the $\mathrm{BGH} / \mathrm{IGH}$ ratios in Table 5 that the major form of $\mathrm{GH}$ produced in mixed and type 2 somatotrophs is BGH. In type 1 somatotrophs approximately equal amounts of BGH and IGH were produced. If the $\mathrm{BGH}$ and IGH values are considered to be independent, than the per thousand somatotroph net GH production for type 1 somatotrophs $(825+856=1681 \mathrm{ng} / 1000$ somatotrophs) was slightly more than type 2 somatotrophs (1394+61.6=1456 ng / 1000 somatotrophs). In actuality, BGH and IGH values are not independent since classical pituitary-derived $\mathrm{GH}$ possesses considerable activity in the tibial assay. Nevertheless, the aforementioned comparison was made to demonstrate that, contrary to the findings of Grindeland and Hymer [36], in this experiment type 2 somatotrophs did not produce significantly more GH than type 1 somatotrophs. It is unknown why this occurred; a probable cause is that separation of somatotrophs was incomplete. Considering the relatively large amounts of BGH produced and secreted from type 1 somatotrophs (compared to the results of Grindeland and Hymer), this explanation seems reasonable. The type 1 cell pool could have contained some type 2 somatotrophs. Overall, based on the percentage somatotrophs, the relative amounts 
of $\mathrm{BGH}$ and IGH secreted, and the BGH/IGH activity ratios in the 3 different cell groups, it is evident that the cell separation procedure in experiment $F$ was successful, and that the 12-day culture results were in agreement with the results of Grindeland and Hymer [36]. As with experiment $E$, however, the spost-gradient cell viability for type 2 cells $(68 \%)$ was markedly lower than for type $1(84 \%)$ or mixed cells $(80 \%)$. The type 2 cell viability on days 4,8 , and 12 was 83 , 96 , and $71 \%$, respectively. These values are certainly acceptable for valid in vitro somatotroph study. However, the repeated observation (experiments $E$ and $F$ ) that type 2 cell viability is lower than mixed or type 1 cells raised the question of whether or not incubation with BSA affects cell viability. It was agreed by all involved that the viabilities obtained in experiment $F$ were acceptable for subsequent work.

In experiment $G$, dose response curves to rGRF-43 were generated in mixed, type 1 and type 2 somatotrophs. Results are not shown in graphic form, as the lower dose data points occurred so close together that display was difficult. As indicated in the results section, the dilution curve for $\mathrm{BGH}$ secretion from three treatment groups (mixed cells - $6.25 \mathrm{nM}$, type 2 cells $-0.39 \mathrm{nM}$, and type 2 cells - $3.13 \mathrm{nM}$ ) differed significantly from the slope of the standard curve, and should be considered as an estimate only. With the exception of IGH secretion from type 2 somatotrophs, BGH and IGH secretion for all groups reached a maximum at $1.56 \mathrm{nM}$. For type 2 somatotrophs, IGH secretion was maximal at $3.13 \mathrm{nM}$. At the 
maximum dose of $1.56 \mathrm{nM}$, per thousand somatotrophs, IGH secretion was greatest in type 1 somatotrophs, followed by mixed somatotrophs, and type 2 somatotrophs, as would be expected given the results of previous studies (Grindeland and Hymer [36] and experiment F). The ED50s for mixed, type 1, and type 2 somatotrophs differed, being 1.0, 1.1, and $1.3 \mathrm{nM}$, respectively, as determined from the dose-response curves shown in Figure 7. The BGH data for the 3 cell groups were too variable to obtain accurate ED50 values. When the data in Table 6 are examined carefully, it can be seen that after BGH and IGH secretion for the 3 groups peaked (about $1.56 \mathrm{nM}$ ) there was a considerable decline in secretion reaching a minimum at 12.5 to $25 \mathrm{nM}$, followed by a second increase in IGH secretion reaching another peak at about $100 \mathrm{nM}$. This curious biphasic result has not been reported elsewhere, but seems to be valid. In the original report on rGRF-43 by Speiss, Rivier, and Vale [100], IGH dose-response curves up to $12.5 \mathrm{nM}$ were reported.

Maximal secretion occurred at 0.5 to $2.5 \mathrm{nM}$ for both native and synthetic rGRF-43, but declined by about $12 \%$ at the $2.5 \mathrm{nM}$ dose for native rGRF-43, and declined by about $12 \%$ for synthetic rGRF-43 at $12.5 \mathrm{nM}$. Their results were not as dramatic as those shown in Table 6 , but they did not report doses higher than $12.5 \mathrm{nM}$. Since no other researchers have published results using GRF doses higher than that which produces the maximal $\mathrm{GH}$ secretory response $(\approx 2 \mathrm{nM})$, it cannot be determined whether this is a repeatable phenomenon. Yet the results of Speiss et al. [100] suggest that this biphasic response 
to GRF may be repeatable. Given that this observation is real, the mecharism of the response, and its physiological significance, remain open to speculation.

Table 7 shows the maximal percent increase over control BGH and IGH secretion for the three cell groups. Though the absolute amount of maximal-dose $\mathrm{BGH}$ released per thousand type 2 somatotrophs (528 ng / 1000 somatotrophs) was 2.3-times greater than in type 1 somatotrophs (229 $\mathrm{ng} / 1000$ somatotrophs), the increase over type 2 control secretion was only $310 \%$ compared to $560 \%$ for type 1 somatotrophs. By this analysis the type 1 somatotroph appears to be more sensitive to rGRF-43 than the type 2 somatotroph. A better comparison would be to consider BGH ED50s, but as indicated, this was not possible due to high variability in the data. At most GRF doses, the BGH/IGH ratio was severaltimes higher in type 2 somatotrophs than in type 1 somatotrophs. In neither type 1 nor type 2 cell groups, were steadily increasing $\mathrm{BGH} / \mathrm{IGH}$ ratios seen during increasing GRF dose, as were found in experiment A (Figure 1B). In mixed cells, BGH secretion at $100 \mathrm{nM}$ was 1.5-times greater than at $1.56 \mathrm{nM}$ (Table 6), suggesting a response pattern similar to that of experiment $A$, though diminished. The mixed cell BGH/IGH ratio also increased from 2.4 at $1.56 \mathrm{nM}$ to 4.3 at $100 \mathrm{nM}$, with intermediate GRF doses yielding intermediate $\mathrm{BGH} / \mathrm{IGH}$ ratios. Since a similar pattern was not seen in either type 1 or type 2 somatotrophs, the mechanism of the response remains unknown. 
The results of experiment $G$ demonstrate: 1) that the $B G H$ and IGH responses to hpGRF-40 in experiment $A$ were a composite result of type 1 and type 2 somatotroph secretion; 2) that both type 1 and type 2 somatotrophs increase release of both BGH and IGH in response to rGRF-43; 3) that type 1 and type 2 somatotrophs have similar dose-responses to rGRF-43 in terms of BGH and IGH maximal doses, and IGH ED50s; 4) that maximal GRF-stimulated BGH secretion from type 2 somatotrophs is 2.3-times greater than for type 1 somatotrophs; and 5) that maximal GRF-stimulated IGH secretion from type 2 somatotrophs is 1.3-times less than for type 1 somatotrophs. The majority of $\mathrm{BGH}$ released in vivo in rats is apparently derived from type 2 somatotrophs, as indicated by results from experiment $G$ during GRF-stimulation and data obtained from 4-day cultures in the absence of GRF, experiment $F$. The results of experiment $G$ also demonstrate that it is unlikely that separate GRFs govern the release of BGH and IGH through independent regulation of somatotroph types, since rGRF-43 stimulates release of both forms of $\mathrm{GH}$ from both cell types. Thus, it seems reasonable that combinations of GRF and some other factor control the selective release of $\mathrm{BGH}$, presumably through inhibition of type 1 somatotroph secretion with simultaneous stimulation of type 2 somatotroph secretion. The most likely candidate for interaction with GRF is SRIF since this is a well-established regulatory peptide affecting $\mathrm{GH}$ release. Experiments $I$ and $J$ were designed to specifically examine the effects of GRF and SRIF, alone, and in 
combination, on the release of BGH and IGH from the 3 cell groups. It was once again observed that in experiment $G$, post-gradient type 2 cell viability was $40 \%$ compared to $81 \%$ in type 1 cells, and $92 \%$ in mixed cells. Since this was the third incidence in 3 cell separation experiments in which type 2 cell viability was low, it was decided that formal investigation of this problem was critical before further work was performed.

The formal investigation of the effects of 45-minute incubation of mixed, dispersed pituitary cells in $1.078 \mathrm{~g} / \mathrm{mL}$ BSA (experiment $\mathrm{H}$ ) indicated that the BSA incubation is without measurable effect on cell viability and basal or GRF-stimulated BGH or IGH secretion when compared with cells incubated at room temperature $\left(R T ; 22-24^{\circ} \mathrm{C}\right.$ ). In replicate experiments (experiment $\mathrm{H} 1$ and $\mathrm{H}_{2}$; Figure 8 and 9 , respectively) it was found that there was no pattern in the data which suggested that BSA incubation affected cell function. Pre- and post-BSA incubation viabilities were in good agreement in both experiments. Though some differences were occasionally noted between GH secretion between groups, there was no consistent pattern. In some cases secretion for the BSA group was higher than in the RT group, while in other cases the situation was reversed. Incubation at $5^{\circ} \mathrm{C}$ for 45 minutes was also without effect, as would be expected given that BSA-incubation at $5^{\circ} \mathrm{C}$ was also without effect. Since type 2 cell viability was consistently low in experiments $E, F$, and $G$, the results of experiment $H$ raise the important question of why this occurred and, secondly, can the 
qualitative results of experiments $E, F$, and $G$ be considered valid with such low viability in type 2 cells? Typically, cells for viability determinations were incubated for 20 minutes in viability media prior to differential cell counting with a hemocytometer. On one occasion the procedures were so time-consuming that cells had to incubate for about 45 minutes prior to cell counting. It was observed that the counting process was considerably easier than with the 20 minute incubation period, since the cells had taken up more neutral red! In procedures with mixed cells that were processed at room temperature, this change in procedure did not affect viability. However, as will be mentioned below for experiments $\mathrm{I}$ and $\mathrm{J}$, this change yielded type 2 cell viabilities that did not differ from mixed or type 1 cells. It seems likely that the cell separation procedure might transiently affect metabolic rate in type 2 cells, thus leading to a decreased rate of transport of neutral red across the plasma membrane. Alternately, type 2 cells may simply transport neutral red at a slower rate than type 1 cells and if one waits long enough accurate viability data can be obtained with this technique. It was concluded, therefore, that the low type 2 cell viability in experiments $E, F$, and $G$ were probably artifactual and conclusions reached were valid.

Experiment I examined the effects of GRF and SRIF alone, and in combination, on both BGH and IGH secretion from mixed, type 1 , and type 2 somatotrophs. In all 3 cell groups GRF treatment caused a dose-related increase in both $\mathrm{BGH}$ and IGH secretion. In mixed 
cells, both BGH and IGH were secreted in parallel during GRFtreatment (no change in BGH/IGH ratios). In type 1 cells, $1.0 \mathrm{nM}$ GRF treatment produced an increase in the $B G H / / G H$ ratio relative to controls or $0.25 \mathrm{nM}$ GRF treatment. In type 2 cells, $1.0 \mathrm{nM}$ GRF treatment produced a decrease in the $\mathrm{BGH} / \mathrm{IGH}$ ratio relative to controls or $0.25 \mathrm{nM}$ GRF treatment. This indicates that type 1 and type 2 somatotrophs differ in response to rGRF-43. Type 1 and type 2 somatotrophs also differ in their percent increase over control BGH and IGH secretion during GRF-treatment (Table 9). With the exception of IGH secretion in response to $1.0 \mathrm{nM}$ GRF, the percent increase over control secretion was consistently greater for type 1 somatotrophs. This is consistent with $B G H$, but not IGH secretion in experiment G (Table 7). During control and GRF treatment, BGH secretion was consistently several-times greater in type 2 somatotrophs than in type 1 somatotrophs, findings consistent with the results of experiments $E, F$, and G, and Grindeland and Hymer [36]. Based on these results, and the fact that each somatotroph type represents about $50 \%$ of the total somatotrophs, it seems reasonable to conclude that in mixed cells, the majority of BGH secretion in the absence of secretagogue and during GRF-treatment comes from type 2 somatotrophs, while IGH secretion in mixed cells is about equally from type 1 and type 2 somatotrophs (Table 8, Figure 10). On the basis of these data, it is clear that the results for mixed cell secretion are due to secretion of different $\mathrm{GH}$ forms from the 2 somatotroph types. 
Treatment with SRIF alone suppressed both BGH and IGH secretion from mixed and type 1 somatotrophs to $40-4 i \%$ of control secretion, and was maximally suppressed with the $0.5 \mathrm{nM}$ dose (Table 8, Table 10). The SRIF-induced maximal inhibition of IGH release from mixed cells was in agreement with the results of Brazeau et al. [14]. In their work, $5.0 \mathrm{nM}$ SRIF inhibited IGH release to $34 \%$ of control. In type 2 somatotrophs IGH secretion was suppressed in a dose-related manner to $59 \%$ and $42 \%$ of control secretion with 0.5 and $10 \mathrm{nM}$ SRIF, respectively. The results for type 2 somatotroph BGH secretion during SRIF treatment (Table 8, Table 10) were quite surprising, suggesting that $0.5 \mathrm{nM}$ SRIF has a stimulatory effect on BGH release (Table 10). It seems unlikely, that this is the case, however, since type 2 cell BGH secretion in the presence of $10 \mathrm{nM}$ SRIF was 1.4-times less than in the presence of $0.5 \mathrm{nM}$ SRIF. On the basis of these data it se ms reasonable to conclude that SRIF does not suppress (or minimally suppresses) BGH release from type 2 somatotrophs at doses as high as $10 \mathrm{nM}$. Further evaluation of this statement will be considered below when the results of the repeat experiment $\mathrm{J}$ are discussed. Despite the apparently anomalous results for type 2 somatotroph BGH secretion in the presence of 0.5 nM SRIF, it can be seen in Figure 10 that the two somatotroph types respond differently to SRIF. It can also be seen in Figure 10 that the mixed cell BGH and IGH secretion does not mirror the composite results for type 1 and type 2 somatotrophs. This finding is not unusual since it has been observed previously (experiment $F, G$, and 
Hymer and Grindeland [36]). However, most often the composite pattern of secretion from type 1 and type 2 cells is reflected in the mixed cell data. It is thus not clear why BGH secretion from type 2 somatotrophs during SRIF treatment deviated so sharply from the expected pattern based on mixed cell secretion (Figure 10). Perhaps some paracrine communication between the two somatotroph types, or other cell types, was disrupted as a result of the cell separation procedure. It is important to note, that approximately $80 \%$ of the type 1 cell fraction is comprised of a mixture of corticotrophs, mammotrophs, gonadotrophs, thyrotrophs and other pituicytes. Similarly, about $15 \%$ of high density cells is comprised of other pituicytes, though of a lower density than in type 2 somatotrophs.

The effects of combined GRF and SRIF treatments demonstrated the most profound differences between cell types and offered an explanation of the mechanism of selective release of $B G H$ during stress in rats. In mixed cells the combined $1.0 \mathrm{nM}$ GRF / $0.5 \mathrm{nM}$ SRIF treatment produced a large suppression of both $\mathrm{BGH}$ and IGH secretion relative to the $1.0 \mathrm{nM}$ GRF treatment alone (Figure 10). However, both $\mathrm{BGH}$ and IGH secretion remained stimulated relative to controls (Table 11). The BGH/IGH ratio for secreted $\mathrm{GH}$ for the aforementioned treatment was increased to 1.68 relative to 1.42 in controls (Table 8). The combined 1.0 nM GRF / $10 \mathrm{nM}$ SRIF treatment produced an even larger suppression of both BGH and IGH secretion relative to the 1.0 nM GRF treatment alone (Figure 10). In the $1.0 \mathrm{nM}$ GRF / $10 \mathrm{nM}$ SRIF treatment group, both BGH and IGH secretion were suppressed below 
control levels (Table 11), though suppression of IGH was greater than $\mathrm{BGH}$, thereby causing an increase in the $\mathrm{BGH} / \mathrm{IGH}$ ratio to 3.42 (compare with 1.42 for control, Table 8). Since stress in rats causes an inhibition of IGH release [1, 35, 104, 105, 106], release of SRIF [1, $105,106]$, and presumptive release of $\operatorname{GRF}[50,53]$, it is reasonable to assume that the selective release of $\mathrm{BGH}$ during stress in rats [52, $54,68,104]$ is due to the combined effects of hypothalamic GRF and SRIF on somatotrophs. The in vitro mixed cell response to $1.0 \mathrm{nM}$ GRF / $0.5 \mathrm{nM}$ SRIF treatment are in accordance with this reasoning. The results fit well with this view and appear to support the experimental hypothesis that combinations of GRF and SRIF cause selective release of $\mathrm{BGH}$. This view is strengthened by the fact that the effects of only 2 dose combinations were examined. If a more complete range of doses were examined, it seems likely that a combination could be found which would suppress IGH secretion to below control levels while simultaneously stimulating BGH secretion. Based on the results of experiment $\mathrm{I}$, the cellular origin of the selective release phenomenon is in type 2 somatotrophs. As can be seen in Figure 10, both BGH and IGH secretion from type 1 somatotrophs were suppressed to levels below control secretion with $1.0 \mathrm{nM}$ GRF treatment in combination with either $0.5 \mathrm{nM}$ or $10 \mathrm{nM}$ SRIF. Suppression of IGH release was related to the SRIF dose in combination with GRF (Table 11). In type 2 somatotrophs the combined treatments suppressed IGH secretion to control levels (Figure 10, Table 11), but simultaneously stimulated BGH secretion to 
149 and 139 percent of control secretion (1.0 nM GRF in combination with $0.5 \mathrm{nM}$ and $10 \mathrm{nM}$ SRIF, respectively). The $\mathrm{BGH} / \mathrm{IGH}$ ratios for secreted GH during combined GRF and SRIF treatments decreased for type 1 cells and increased for type 2 cells relative to the appropriate controls (Table 8). This finding is consistent with the associated $\mathrm{BGH} / \mathrm{IGH}$ ratios for mixed cell treatments, and with in vivo results already mentioned. The results are also in agreement with the findings of Grindeland et al. [38], which demonstrated that, compared to controls, mixed and type 2 somatotrophs from cold-exposed $\left(4^{\circ} \mathrm{C}\right.$, 1h) donor rats release 40 and $75 \%$ less BGH during 4-day culture. Secretion of IGH was unaffected in all 3 cell groups, and type 1 cell BGH secretion was also unaffected by cold exposure.

Though the chemical nature and functional significance of the different forms of $\mathrm{GH}$ released from the 2 somatotroph populations remains to be determined, these data demonstrate several important points: 1) bioassay of $\mathrm{GH}$ is an important tool in the evaluation of $\mathrm{GH}$ physiology; 2) secretion of BGH and IGH are under differential regulation by hypothalamic GRF and SRIF; 3) the majority of BGH is derived from type 2 somatotrophs and; 4) there is a functional heterogeneity of pituitary somatotrophs.

Experiment $J$, an exact replication of experiment $\mathrm{I}$, examined the effects of GRF and SRIF alone, and in combination, on both BGH and IGH secretion from mixed, type 1, and type 2 somatotrophs. As in experiment I, GRF treatment caused a dose-related increase in both BGH and IGH secretion in all 3 cell groups. In mixed cells, both 
BGH and IGH were secreted in parallel during GRF-treatment (no change in $B G H / I G H$ ratios), replicating experiment 1 data. In contrast to experiment I, $1.0 \mathrm{nM}$ GRF treatment of type 1 cells did not produce an increase in the BGH/IGH ratio relative to controls or $0.25 \mathrm{nM}$ GRF treatment. Rather, the ratio was unchanged. In agreement with experiment I, both $0.25 \mathrm{nM}$ GRF and $1.0 \mathrm{nM}$ GRF treatments of type 2 cells produced a decrease in the $B G H / I G H$ ratio relative to controls. Though the values differ between experiments, the results replicate the observation that type 1 and type 2 somatotrophs differ in response to rGRF-43. Type 1 and type 2 somatotrophs also differ in their percent increase over control BGH and IGH secretion during GRF-treatment (Table 13). In contrast to experiment I (where the percent increase over control BGH and IGH secretion was greatest for type 1 somatotrophs) the percent increase over control BGH and IGH secretion was greatest for type 2 somatotrophs. This variability between experiments is likely due to variation in completeness of cell separation between experiments. Since separation of type 1 and 2 somatotrophs is never perfect with the density gradient procedure, some of the more subtle differences between cell types can only be resolved by performing several replicate experiments (recall that for experiments $I$ and $J$ cells were derived from a common "pool" of approximately 100 anterior pituitaries per experiment). During control and GRF treatment, BGH secretion was consistently several times greater in type 2 somatotrophs than in type 1 somatotrophs, findings consistent with the results of 
experiments E, F, G and I, and Grindeland and Hymer [36]. As with experiment $\mathrm{I}$, it is apparent that the majority of $\mathrm{BGH}$ secretion, in the absence of secretagogue and during GRF-treatment, comes from type 2 somatotrophs, while IGH secretion in mixed cells is contributed about equally from type 1 and type 2 somatotrophs (Table 12, Figure 11).

Treatment with SRIF alone suppressed both BGH and IGH secretion from mixed and type 1 somatotrophs to $24-48 \%$ of control secretion, and was maximal with the $0.5 \mathrm{nM}$ dose (Table 12, Table 14). As in experiment $\mathrm{I}$, the SRIF-induced maximal inhibition of IGH release from mixed cells was in agreement with the results of Brazeau et al. [14]. In their work, $5.0 \mathrm{nM}$ SRIF inhibited IGH release to $34 \%$ of control. In type 2 somatotrophs, IGH secretion was suppressed to $47 \%$ and $45 \%$ of control secretion with 0.5 and $10 \mathrm{nM}$ SRIF, respectively. BGH secretion from type 2 somatotrophs was suppressed to $61 \%$ and $64 \%$ of control secretion with 0.5 and $10 \mathrm{nM}$ SRIF, respectively (Table 12, Table 14). It appears that both BGH and IGH secretion were already maximally suppressed with the low SRIF dose of $0.5 \mathrm{nM}$, a result somewhat different than in experiment 1 . Though the effect of SRIF in experiment 1 appeared to be doserelated, note that the $0.5 \mathrm{nM}$ dose seemed to have a stimulatory effect on BGH secretion. Experiment $J$ supports the conclusion that experiment I was in error in this regard. Despite minor variablity between experiments, it can be seen in Figure 11 that the two somatotroph types respond differently to SRIF. It can also be seen in 
Figure 11 that the composite pattern of secretion from type 1 and type 2 cells is reflected in the mixed cell results.

As in experiment $\mathrm{I}$, the effects of combined GRF and SRIF treatments demonstrated the most profound differences between cell types and offered an explanation of the mechanism of selective release of $\mathrm{BGH}$ during stress in rats. In mixed cells, the combined 1.0 nM GRF / $0.5 \mathrm{nM}$ SRIF treatment produced a suppression of both BGH and IGH secretion relative to the $1.0 \mathrm{nM}$ GRF treatment alone (Figure 11). However, both $B G H$ and IGH secretion remained stimulated relative to controls (Table 15). This result is in agreement with experiment $\mathrm{I}$. Also in agreement, the $\mathrm{BGH} / \mathrm{IGH}$ ratio for secreted $\mathrm{GH}$ for the 1.0 nM GRF / $0.5 \mathrm{nM}$ SRIF treatment was increased to 4.2 relative to 3.6 in controls (Table 12). The combined $1.0 \mathrm{nM}$ GRF / 10 nM SRIF treatment produced an even larger suppression of both BGH and IGH secretion relative to the $1.0 \mathrm{nM}$ GRF treatment alone (Figure 11). In the $1.0 \mathrm{nM}$ GRF / $10 \mathrm{nM}$ SRIF treatment group, both BGH and IGH secretion were suppressed below control levels (Table 15), though suppression of IGH was greater than BGH, thereby causing an increase in the BGH/IGH ratio to 6.3 (compare with 3.6 for control- Table 12). It has already been mentioned, but is worth repeating that stress in rats causes an inhibition of IGH release $[1,35,104,105,106]$, release of SRIF $[1,105,106]$, and presumptive release of GRF $[50,53]$. For these reasons it is reasonable to assume that the selective release of $\mathrm{BGH}$ during stress in rats $[52,54,68,104]$ is due to the combined effects of hypothalamic GRF and SRIF on somatotrophs. The 
in vitro mixed cell response to $1.0 \mathrm{nM}$ GRF / $0.5 \mathrm{nM}$ SRIF treatment are in accordance with this reasoning. The results fit well with this view. Furthermore, they appear to support the experimental hypothesis that combinations of GRF and SRIF cause selective release of BGH. This view is strengthened by the fact that the effects of only 2 dose combinations were examined. If a more complete range of doses were examined, it seems likely that a combination could be found which would suppress IGH secretion to below control levels while simultaneously stimulating BGH secretion.

Based on the results of experiments $\mathrm{I}$ and $\mathrm{J}$, the cellular origin of the selective release phenomenon is in type 2 somatotrophs. This has already been discussed for experiment $\mathrm{I}$. For experiment $\mathrm{J}$, it can be seen (Figure 11) that, with the exception of IGH secretion from 1.0 nM GRF / 0.5 nM SRIF group, both BGH and IGH secretion from type 1 somatotrophs were suppressed to levels below control secretion during both of the combined GRF/SRIF treatments. Suppression of IGH release was related to the SRIF dose in combination with GRF (Table 15). In type 2 somatotrophs the combined treatments suppressed BGH secretion to control levels (Figure 11, Table 15), and simultaneously stimulated IGH secretion to $472 \%$ and $136 \%$ of control secretion (1.0 $\mathrm{nM}$ GRF in combination with $0.5 \mathrm{nM}$ and $10 \mathrm{nM}$ SRIF, respectively). This is in contrast to experiment $\mathrm{I}$, in which BGH secretion was stimulated and IGH secretion was suppressed to control levels during the combined treatments. It is not clear why the 2 experiments differed, though it may be related to differences in the completeness 
of cell separation between the two experiments. Whatever the cause of the discrepancy for type 2 cells, the pattern of effects of GRF and SRIF on BGH and IGH secretion from mixed somatotrophs were equivalent in experiment $\mathrm{I}$ and $\mathrm{J}$. Moreover, it is apparent from these experiments that the majority of the mixed cell $B G H$ secretion was from type 2 somatotrophs. Therefore, since the mixed cell BGH/IGH ratio increased during combined GRF/SRIF treatments (experiments I and $\mathrm{J}$ ) it is reasonable to conclude that the type 2 somatotroph is less sensitive to SRIF (in terms of BGH secretion) than is the type 1 somatotroph. The data from the SRIF treatments alone (Table 14) also support the conclusion that type 2 somatotrophs are less sensitive to SRIF in terms of BGH secretion. Note that in Table 14 IGH secretion is suppressed to a greater extent than BGH secretion during SRIF treatment in type 2 cells.

Evidence for multiple molecular forms of growth hormone was presented above (see Introduction and Literature Review). In light of the multiple physiological effects that have been demonstrated for growth hormone (increased transport of amino acids across the plasma membrane, increased protein synthesis, mitosis of many cell types, early insulin-like and delayed anti-insulin effects such as increased lipolysis) it is tempting to speculate that the differential control of BGH and IGH release from type 1 and 2 somatotrophs is of physiological significance. Based on the results of experiments $I$ and $\mathrm{J}$, in vivo results indicating that both GRF and SRIF are released during stress in rats (see above), and results showing that cold- 
stress in rats depletes only BGH from type 2 cells (and neither BGH or IGH from type 1 cells [38]) it is possible to propose a theory for the control of BGH and IGH secretion from type 1 and 2 somatotrophs. It is proposed that in rats, stressors such as $4^{\circ} \mathrm{C}$ for 30 minutes, insulin-induced hypoglycemia, or overnight fasting (see Introduction and Literature Review section) cause hypothalamic release of GRF and SRIF in a GRF/SRIF concentration ratio in the approximate range of 0.1 to 2 with absolute concentrations similar to those used in experiments $\mathrm{I}$ and $\mathrm{J}$. It is also proposed that the type 2 somatotroph is less sensitive to SRIF in terms of BGH release and that the above combinations of GRF and SRIF produce an increase or no change in plasma concentration of $\mathrm{BGH}$. with a concomitant decrease in the plasma concentration of IGH. The resultant increase in the ratio of $\mathrm{BGH} / \mathrm{IGH}$ mediates as yet undetermined physiological responses that are of benefit to the "stressed" animal. This theoretical framework could provide the basis for numerous future investigations of GRF and SRIF receptor affinities and concentrations, post-receptor differences, differences in secretory granules and enzymes for processing $\mathrm{GH}$, etcetera. Additionally, it will be important to determine differences in physiological effects of BGH and IGH on various tissues. Some important questions remaining unanswered are: 1) Are type 1 and 2 somatotrophs discrete cell types or are they interconvertible?; 2) Are there 2 types of secretory granules or are BGH and IGH co-localized in a single type of secretory granule?; 3) Do the quantities and/or affinities of GRF and SRIF receptors differ 
between cell types?; and 4) How is the BGH/IGH ratio of $\mathrm{GH}$ released from a single cell controlled intracellularly? The answers to some of these important questions will undoubtedly broaden our understanding of one of the most important regulators of cellular metabolism, but will also broaden our understanding of hormone and neurotransmitter release in general.

The GH system is not unique in containing cells which store and release more than one form of hormone. Corticotrophs have been shown to synthesize and release both adrenocorticotropin and Bendorphin [116], while gonadotrophs have been shown to store and release both follicle-stimulating hormone and luteinizing hormone [74]. Some of the adrenergic cells of the adrenal gland contain dopamine, epinephrine, norepinephrine, adenosine triphosphate, dopamine-B-hydroxylase, and phenylethanolamine- $\mathrm{N}$ methyltransferase, all localized in the same secretory granules [113]! The GH system is apparently not alone in possessing cells which contain more than one hormone type. It is also known that insulin complexes with zinc within beta cell secretory granules [73]. Perhaps GH is complexed in some analogous fashion, thereby producing a decrease in immunoactivity with no loss in bioactivity. It is unlikely that the answers to these complex questions will be simple or be found quickly, but the discoveries significantly increase our understanding of the physiology of the growth hormone system. 


\section{v. SUMMARY AND CONCLUSIONS}

1. This research has shown that rat somatotrophs are functionally heterogeneous in both their secretory activity and regulation by hypothalamic hormones as evidenced by:

- Differing quantities and ratios of BGH and IGH secreted.

- Greater sensitivity of type 1 cells to SRIF.

- Greater effect of SRIF on IGH than on BGH secretion by type 2 cells.

2. During GRF treatment, BGH and IGH are released with similar percent increases over control secretion for both $\mathrm{GH}$ forms.

3. Bioassay of $\mathrm{GH}$ is an important adjunct to the immunoassay in the evaluation of $\mathrm{GH}$ physiology.

4. The combined GRF/SRIF data are consistent with earlier work by Grindeland and Hymer in which cold stress ( $4^{\circ} \mathrm{C}, 30 \mathrm{~min}$.) of rats depletes BGH but not IGH from type 2 somatotrophs, without effect on IGH or BGH in type 1 somatotrophs.

5. Since there is evidence that both SRIF and GRF are released during environmental stress in rats, the results presented here could explain the unchanged or decreased IGH levels and elevated BGH levels in plasma of "stressed" rats. 


\section{Appendix A: Procedures for Preparation of Media and}

\section{Solutions}

\section{Media A}

Media A was Spinner's Minimum Essential Medium (SMEM; Gibco Cat. no. 410-1400; Grand (sland, NY), $10 \mathrm{~mL} / \mathrm{L}$ of $10,000 \mathrm{U} / \mathrm{mL}$ Penicillin and 10,000 $\mu \mathrm{g} / \mathrm{mL}$ streptomycin (Penn-Strep; GIBCO Cat. \#600-5140; Grand Island, NY), and $0.1 \%$ crystalline bovine serum albumin (BSA; Cat. \#A4378; Sigma Chemical Co.; St. Louis, MO) adjusted to $\mathrm{pH} 7.3$ with $\mathrm{NaOH}$.

\section{Media B - Dissociation Media}

Media B consisted of media A with $3 \%$ w/v BSA (final percentage), $0.3 \% \mathrm{w} / \mathrm{v}$ Trypsin (Difco, 1:250), $0.02 \mathrm{mg} / \mathrm{mL}$ deoxyribonuclease (DNase; Cat. \#D-5025; Sigma Chemical Co.; St. Louis $\mathrm{MO}$ ), adjusted to $\mathrm{pH} 7.6$ with $\mathrm{NaOH}$.

\section{Media C - Primary Culture Media}

Media C was alpha-modified Eagle's media (Cat. no. 10-311; Flow Laboratories; McLean, VA), $1 \%$ w/v crystalline BSA (Cat. \#A4378; Sigma Chemical Co.; St. Louis, MO), 5\% v/v calf serum (Cat. \#200-6170AG; GIBCO; Grand Island, NY), 10 mL/L Penn-Strep, 10 mg/L Gentamycin sulfate (Cat. \#G-3632; Sigma Chemical Co.; St. Louis, Missouri), $25 \mathrm{mM}$ hydroxyethylpiperazine-N-2-ethane-sulfonic 
acid (HEPES; Cat. no. H-0506; Sigma Chemical Co.; St. Louis, MO), and $0.2 \%$ sodium bicarbonate, adjusted to $\mathrm{pH} 7.4$.

\section{BSA Stock Solution and Unbalanced Salt Solution (UBSS)}

Fraction V BSA was exhaustively dialyzed $(200 \mathrm{~mL}$ of BSA solution dialyzed against $17 \mathrm{~L}$ of double distilled water for 3 days with water changes twice daily), freeze dried, and reconstituted in an unbalanced salt solution (UBSS) to a stock of $40 \%(w / w)$. UBSS is $0.801 \% \mathrm{w} / \mathrm{v} \mathrm{NaCl}, 0.034 \% \mathrm{w} / \mathrm{v} \mathrm{KCl}, 0.025 \% \mathrm{w} / \mathrm{v} \mathrm{CaCl}, 0.016 \% \mathrm{w} / \mathrm{v}$ $\mathrm{KH}_{2} \mathrm{PO}_{4}, 0.028 \% \mathrm{w} / \mathrm{v} \mathrm{MgSO}_{4}$ in deionized + distilled water. The $40 \%$ BSA stock was filter-sterilized through a series of $8.0 \mu \mathrm{m}, 3.0 \mu \mathrm{m}$, $1.2 \mu \mathrm{m}$, and $0.45 \mu \mathrm{m}$ filters. The UBSS was filter sterilized through a $0.22 \mu \mathrm{m}$ filter. In a $4^{\circ} \mathrm{C}$ cold room in a sterile work field, solutions of $1.071 \mathrm{~g} / \mathrm{mL}$ and $1.085 \mathrm{~g} / \mathrm{mL}$ were prepared using Shortman's procedure [96].

\section{Neutral Red Stock Solution}

A $0.1 \% \mathrm{w} / \mathrm{v}$ neutral red stock solution was prepared by dissolving dye (Cat. \#NX265; Matheson Coleman \& Bell; Norwood, Ohio) in distilled water in a conical flask, mixing well, covering with aluminum foil and autoclaving at 15 p.s.i. for 15 minutes. When the solution was cooled, a rubber stopper was inserted, the top was covered with aluminum foil, and the solution was stored at room temperature for repeated use. 


\section{Zamboni's Fluid}

Zamboni's fixative was prepared as follows: in a fume hood, 20 $\mathrm{g}$ of paraformaldehyde was added to $50 \mathrm{mLs}$ of distilled water and heated to $60^{\circ} \mathrm{C}$. Sodium hydroxide $(1.0 \mathrm{~N})$ was added dropwise until the solution became clear. The solution was then filtered hot through Whatman \#1 filter paper and allowed to cool. Saturated picric acid $(75 \mathrm{~mL})$ was added, and the solution was brought to 500 $\mathrm{mL}$ with phosphate buffer $\left(3.31 \mathrm{~g} \mathrm{Na} \mathrm{H}_{2} \mathrm{PO}_{4} \cdot \mathrm{H}_{2} \mathrm{O}\right.$ and $33.77 \mathrm{~g}$ $\mathrm{Na}_{2} \mathrm{HPO}_{4} \cdot 7 \mathrm{H}_{2} \mathrm{O}$ per liter $\mathrm{H}_{2} \mathrm{O} ; \mathrm{pH} 7.3$ ). The solution was stored at $4^{\circ} \mathrm{C}$ and discarded after one month.

\section{Phosphate Buffered Saline (PBS)}

PBS consists of $8.00 \mathrm{~g} / \mathrm{L} \mathrm{NaCl}, 0.20 \mathrm{~g} / \mathrm{L} \mathrm{KCl}, 2.16 \mathrm{~g} / \mathrm{L}$ $\mathrm{Na}_{2} \mathrm{HPO}_{4} \cdot 7 \mathrm{H} 2 \mathrm{O}, 0.20 \mathrm{~g} / \mathrm{L} \mathrm{KH}_{2} \mathrm{PO}_{4}, 0.05 \mathrm{~g} / \mathrm{L} \mathrm{MgCl}{ }_{2} \cdot 6 \mathrm{H}_{2} \mathrm{O}$, in deionized, distilled water, $\mathrm{pH}$ 7.2.

\section{Kaiser's Glycerol}

Kaiser's glycerol was prepared by soaking $8.0 \mathrm{mLs}$ of gelatin (Cat. \#G-2625; Sigma Chemical Corp.; St. Louis, MO) in $52 \mathrm{mLs}$ of water for 1-2 hours, adding $50.0 \mathrm{mLs}$ of glycerol and $0.01 \mathrm{~g}$ merthiolate, then heating to $60^{\circ} \mathrm{C}$ for 15 minutes while stirring to homogeneity. 


\section{Bibliography}

1. Arimura A, Smith WD, Schally AV 1976 Blockade of the stress-induced decrease in blood GH by antisomatostatin serum in rats. Endocrinology 98:540

2. Barinaga M, Bilezikjian LM, Vale WW, Rosenfeld MG, Evans RM 1985 Independent effects of growth hormone releasing factor on growth hormone release and gene transcription. Nature 314:279

3. Barnard R, Waters MJ 1986 Serum and liver cytosolic growth-hormone-binding proteins are antigenically identical with liver membrane 'receptor' types 1 and 2 . J. Biochem. 237:885

4. Baumann G, Amburn K, Shaw MA 1988 The circulating growth hormone-binding protein complex: a major constituent of plasma GH in man. Endocrinology
$122: 976$

5. Baumann G, Grindeland RE 1990 Personal communication.

6. Beitins EZ, Rattazzi MC, MacGillivray MH 1977 Conversion of radiolabeled human growth hormone into higher molecular weight moieties in human plasma in vivo and in vitro. Endocrinology 101:350

7. Benviste R, Stachura ME, Szabo M, Frohman AA 1975 Big growth hormone (GH): conversion to small GH without peptide bond cleavage. J. Clin. Endocrinol. Metab. 41:422

8. Berelowitz M, Szabo M, Frohman LA, Firestone S, Chu L 1981 Somatomedin-C mediates growth hormone negative feedback by effects on both the hypothalamus
and the pituitary. Science 212:1279

9. Bilezikjian LM, Vale WW 1983 Stimulation of adenosine $3^{\prime}, 5^{\prime}$-monophosphate production by growth hormone-releasing factor and its inhibition by somatostatin in anterior pituitary cells in vitro. Endocrinology 113:1726

10. Bliss, Cl Statistics of Bioassay. 1952 Academic Press, New York. pp 576-579

11. Bloch B, Brazeau P, Ling N, Bohlen P, Esch F, Wehrenberg WB, Benoit R, Bloom F, Guillemin R 1983 Immunohistochemical detection of growth hormone-releasing
factor in brain. Nature $301: 607$

12. Brazeau P, Ling N, Bohlen P, Esch F, Ying S, Guillemin R 1982 Growth hormone releasing factor, somatocrinin, releases pituitary growth hormone in vitro. Proc.
Natt. Acad. Sci. $79: 7903$

13. Brazeau $P$, Ling N, Esch R, Bohlen $P$, Mougin C, Guillemin R 1982 Somatocrinin (growth hormone releasing factor) in vitro bioactivity: $\mathrm{Ca}++$ involvement, CAMP mediated action and additivity of effect with PGE2. Biochem. Biophys. Res Commun.
109:588 
14. Brazeau P, Vale W, Burgus R, Ling N, Butcher M, Rivier J, and Guillemin R 1977 Hypothalamic polypeptide that inhibits the secretion of immunoreactive pituitary growth hormone. Science 179:77

15. Cella SG, Locatelli V, DeGennaro V, Puggioni R, Pintor C, Muller EE 1985 Human pancreatic growth hormone (GH)-releasing hormone stimulates $\mathrm{GH}$ synthesis and release in infant rats. An in vivo study. Endocrinology 116:574

16. Clark RG, Robinson ICAF 1985 Growth induced by pulsatile infusion of an amidated fragment of human growth hormone releasing factor in normal and GHRF. deficient rats. Nature 314:281

17. Clayton RN, Bailey LC, Abbot SD, Detta A, Docherty K 1986 Cyclic adenosine nucleotides and growth hormone-releasing factor increase cytosolic growth hormone messenger RNA levels in cultured rat pituitary cells. J. Endocr. 110:51

18. Cronin MJ, Hewlett EL, Evans WS, Thorner MO, Rogol AD 1984 Human pancreatic tumor growth hormone (GH)-releasing factor and cyclic adenosine 3',5'-monophosphate evoke GH release from anterior pituitary cells: the effects of pertussis toxin, cholera toxin, forskolin, and cycloheximide. Endocrinology 114:904

19. Daughaday WH, Peake GT, Birge CA, Mariz IA 1968 The influence of endocrine factors on the concentration of growth hormone in rat pituitary. In: Pecile $A$ and Muller EE (eds) Growth Hormone. Excerpta Medica, Amsterdam. pp 239-252

20. Daughaday WH, Peake GT, Machlin LJ 1970 Assay of the growth hormonereleasing factor. In: Meites J (ed) Hypophysiotropic Hormones of the Hypothalamus: Assay and Chemistry. Williams \& Wilkins Co., Baltimore. pp 151-
170

21. Denef C, Hautekeete E, De Wolf A, Vanderschueren B 1978 Pituitary basophils from immature male and female rats: distribution of gonadotrophs and thyrotrophs as studied by unit gravity sedimentation. Endocrinology 103:724

22. Deuben RD, Meites $J 1964$ Stimulation of pituitary growth hormone release by a hypothalamic extract in vitro. Endocrinology $74: 408$

23. Ellis S, Grindeland RE 1974 Dichotomy between bioassayable and immunoassayable growth hormone. In: $S$ Raiti (ed.) Advances in Human Growth Hormone Research. Drew Publication No. (NIH) 74-612, US Printing Office,
Washington, D.C.

24. Ellis S, Grindeland RE, Reilly TJ, Yang SH 1976 Studies on the nature of plasma growth hormone. In: Pecile A and Muller EE (eds) Growth Hormone and Related Peptides. Excerpta Medica, Amsterdam. pp 75-83

25. Ellis S, Vodian M, Grindeland R 1978 Studies on the biassayable growth hormonelike activity of plasma. In: Greep RO (ed) Recent Progress in Hormone Research. Academic Press, New York. pp 213 
26. Ernst M, Froesch ER 1988 Growth hormone dependent stimulation of osteoblast-like cells in serum-free cultures via local synthesis of insulin-like growth factor I. Biochem. Biophys. Res. Comm. 151:142

27. Farrington $M$, Hymer WC Characterization of high molecular weight aggregates of rat GH. 70th Annual Meeting of the Endocrine Society, New Orleans LA, 1988 (Abstract no. 239)

28. Frohman LJ, Bernardis LL, Burek L, Maray JW, Dhariwal APS 1972 Hypothalamic control of growth hormone secretion in the rat. In: Pecile A and Muller EE (eds) Growth and Growth Hormone. Excerpta Medica, Amsterdam. pp

29. Garcia JF, Geschwind II 1968 Investigation of growth hormone secretion in selected mammalian species. In: Pecile A and Muller EE (eds) Growth Hormone. Excerpta Medica, Amsterdam. pp 267-291

30. Gelato MC, Merriam GR 1986 Growth hormone releasing hormone. Ann. Rev. Physiol. 48:569

31. Gick GG, Zeytin FN, Brazeau P, Ling NC, Esch FS, Bancroft C 1984 Growth hormone-releasing factor regulates growth hormone mRNA in primary cultures of
rat pituitary cells. Proc. Natl. Acad. Sci. $81: 1553$

32. Glick SM 1968 Normal and abnormal secretion of growth hormone. Ann. N.Y. Acad. Sci. 148:471

33. Greenspan FS, Li CH, Simpson ME, Evans HM 1949 Bioassay of hypophyseal growth hormone: the tibial test. Endocrinology 45:455

34. Greep, RO 1974 History of research on anterior hypophyseal hormones. In: Greep RO and Astwood EB (eds) Handbook of Physiology, Volume IV, Section 7: Endocrinology. The Pituitary Gland and Its Neuroendocrine Control, Part 2. American Physiological Society, Washington, D.C. pp 1-27

35. Grindeland RE 1986 Personal Communication.

36. Grindeland R, Hymer W 1987 Two types of rat somatotrophs secrete growth hormone with different biological and immunological potencies. Submitted to Endocrinology.

37. Grindeland R, Hymer WC, Farrington M, Fast T, Hayes C, Motter K, Patil L, Vasques M 1987 Changes in pituitary growth hormone cells prepared from rats flown on Spacelab 3. Am. J. of Physiology (Regulatory integrative Comp. Physiol.) 21:R209

38. Grindeland RE, Hymer WC, Lundgren P, Edwards C 1982 Differential secretion of bioassayable growth hormone by two types of rat somatotrophs. The Physiologist. 25(4):262

39. Grindeland R, Yang S, Figueroa R 1978 Unpublished results. 
40. Guillemin $R$, Brazeau $P$, Bohlen $P$, Esch $F$, Ling N, Wehrenberg WB, Bloch $B$, Mougin C, Zeytin F, Bair A 1984 Somatocrinin, the growth hormone releasing factor. Recent Progress in Hormone Research 40:233

41. Harris GW 1955 Neural Control of the Pituitary Gland. London, Edward Arnold Ltd. pp 207-221

42. Hunter WM, Greenwood FC 1962 Preparation of iodine-131 labeled human growth hormone of high specific activity. Nature 194:495

43. Hymer W 1986 Personal communication.

44. Hymer W, Grindeland RE 1987 Personal communication.

45. Hymer WC, Hatfield JM $1983^{\circ}$ Separation of cells from the rat anterior pituitary gland. In: Methods in Enzymology, Vol 103. Academic Press, New York. pp 257-287

46. Isaksson OGP, Eden S, Albertsson-Wikland K, Jansson JO, Friberg U, Madsen $K$ 1986 Direct action of growth hormone on cartilage growth. In: Raiti $S$ and Tolman RA (eds) Human Growth Hormone. Plenum Medical Book Company, New
York. pp 563-563

47. Isaksson OGP, Jansson JO, Gause IAM 1982 Growth hormone stimulates longitudinal bone growth directly. Science 216:1237

48. Ishida Y, Kuroshima A, Bowers CY, Schally AV 1965 In vivo depletion of pituitary growth hormone by hypothalamic extracts. Endocrinology 77:759

49. Katz SH, Dhariwal APS, McCann SM 1967 Effect of hypoglycemia on the content of pituitary growth hormone (GH) and hypothalamic growth hormone-releasing factor (GHRF) in the rat. Endocrinology 81:333

50. Knobil E, Meyer V, Schally AV 1968 Hypothalamic extracts and the secretion of growth hormone in the rhesus monkey. In: Pecile A, and Muller EE (eds) Growth Hormone. Excerpta Medica, Amsterdam. pp 226-237

51. Kraicer J, Cowan JS, Sheppard MS, Lussier B, Moor BC 1986 Effect of somatostatin withdrawal and growth hormone (GH)-releasing factor on GH release in vitro: amount available for release after disinhibition. Endocrinology
$119: 2047$

52. Krulich L, McCann SM 1966 Effect of alterations in blood sugar on pituitary growth hormone content in the rat. Endocrinology 78:759

53. Krulich L, McCann SM 1966 Evidence for the presence of growth hormonereleasing factor in blood of hypoglycemic, hypophysectomized rats. Proc. Soc. Exp.
Biol. Med. 122:668 
54. Krulich L, McCann SM 1966 Influence of stress on the growth hormone content of the pituitary of the rat. Proc. Soc. Exp. Biol. Med. 122:612

55. Leung DW, Spencer SA, Cachianes G, Hammonds RG, Collins C, Henzel WJ, Barnard R, Waters MJ, Wood WI 1987 Growth hormone receptor and serum binding protein: purification, cloning, and expression. Nature 330:537

56. Lewis UJ 1984 Variants of growth hormone and prolactin and their posttranslational modifications. Ann. Rev. Physiol. 46:33

57. Lewis UJ, Singh RNP, Peterson SM, Vanderlaan WP 1976 Human growth hormone: a family of proteins. In: Pecile A and Muller EE (eds) Growth Hormone and Related Peptides. Excerpta Medica, Amsterdam-Oxford American Elsevier Publishing Co., Inc., New York. pp 64-74

58. Li CH 1977 Bioassay of pituitary growth hormone. In: C.H. Li (ed) Hormonal Proteins and Peptides. Academic Press, New York. pp $2-41$

59. Li C, Evans HM, Simpson ME .1945 Isolation and properties of anterior hypophyseal growth hormone. J. Biol. Chem. 159:353

60. Liberti JP, Joshi GS 1986 Synthesis and secretion of phosphorylated growth hormone by rat pituitary glands in vitro. Biochem. Biophys. Res. Comm. 137:806

61. Malacara JM, Reichlin S 1971 Elevation of plasma radioimmunoassayable growth hormone in the rat induced by porcine hypothalamic extracts. In: Pecile A and Muller EE (eds) Growth and Growth Hormone. Excerpta Medica, Amsterdam. pp
299-305

62. Malacara JM, Valverde RC, Reichlin S, Bollinger J 1972 Elevation of plasma radioimmunoassayable growth hormone in the rat induced by porcine hypothalamic
extract. Endocrinology $91: 1189$

63. Merchenthaler I, Vigh S, Schally AV, Petrusz P 1984 Immunocytochemical localization of growth hormone releasing factor in the rat hypothalamus. Endocrinology 114:1082

64. Muller E, Pecile A 1965 Growth hormone releasing factor of a guinea-pig hymothalamic extract: its activity in guinea pig and rat. Proc. Soc. Exp. Blol. Med. 119:1191

65. Muller EE, Dal Pra P 1968 Influence of insulin hypoglycemia and cold exposure on the release of pituitary growth hormone in guinea pig and mouse. Gen. and Comp.
Endocr. 10:56

66. Muller EE, Giustina G, Miedico D, Cocci D, Pecile A 1972 Analogous pattern of bioassayable and radioimmunoassayable growth hormone in some experimental conditions of rat and mouse. In: Pecile A and Muller EE (eds) Growth and Growth
Hormone. Excerpta Medica, Amsterdam. pp 283-298 
67. Muller EE, Schally AV, Cocchi D 1971 Increase in plasma growth hormone (GH)like activity after administration of porcine GH-releasing hormone. Proc. Soc. Exp. Biol. Med. 137:489

68. Muller EE, Takashige S, Akira A, Schally AV 1967 Hypoglycemia, stress and growth hormone release: blockade of growth hormone release by drugs acting on the central nervous system. Endocrinology 80:109

69. Murakami Y, Kato Y, Shimatsu A, Inoue T, Koshiyama H, Ishikawa Y, Hattori N, Yanaihara $\mathrm{N}$, and Imura $\mathrm{H}$ The mechanisms involved in growth hormone secretion induced by Galanin in the rat. 70th Annual Meeting of the Endocrine Society, New Orleans LA, 1988 (Abstract no. 666)

70. Parkhie MR, Johnson HD 1971 Existence of a linear log dose response in the bioassay for a hypothalamic somatotrophin stimulating factor as based in rat pituitary somatotrophin content. Neuroendocrinology $8: 1$

71. Pate YC, Srikant CB 1986 Somatostatin mediation of adenohypophysial secretion. Ann. Rev. Physiol. 48:551

72. Pecile A, Muller EE, Felici M, Netti C 1972 Nervous system participation in growth hormone release from the anterior pituitary gland. In: Pecile $A$ and Muller EE (eds) Growth and Growth Hormone. Excerpta Medica, Amsterdam. pp
$261-270$

73. Permutt MA 1981 Biosynthesis of insulin. In: Cooperstein SJ and Watkins D (eds) The Islets of Langerhans. New York, Academic Press. p 75-95

74. Phifer RF, Midgley AR, Spicer SS 1973 Immunologic and histologic evidence that follicle-stimulating hormone and luteinizing hormone are present in the same cell type in the human pars distalis. J. Clin Endocrinol. Metab. 36:125

75. Porter JC, Kamberi IA, Grazia YR .1971 Pituitary blood flow and portal vessels. In: Martini $L$ and Ganong WF (eds) Frontiers in Neuroendocrinology. Oxford University Press, New York. pp 145-175

76. Porter JC, Mical RS, Kamberi IA, Grazia YR 1970 A procedure for the cannulation of a pituitary stalk portal vessel and perfusion of the pars distalis in the rat. Endocrinology 87:197

77. Reichlin S 1974 Regulation of somatotrophic hormone secretion. In: Knobil E and Sawyer W (eds) Handbook of Physiology, Vol IV. American Physiological Society, Washington, D.C. p 427

78. Reichlin S, Schalch DS 1969 Growth Hormone Releasing Factor. In: Gual, C. (ed) Progress in Endocrinology. Excerpta Medica, Amsterdam. pp 584-589

79. Rivier J, Speiss J, Thorner M, Vale W 1982 Characterization of a growth hormone-releasing factor from a human pancreatic islet tumor. Nature 300:276 
80. Rivier JEF 1974 Somatostatin. Total solid phase synthesis. J. of the Am. Chem. Soc. $96(9): 2986$

81. Rodger NW, Beck JC, Burgus R, Guillemin R 1969 Variability of response in the bioassay for a hypothalamic somatotrophin releasing factor based on rat pituitary growth hormone content. Endocrinology 84:1373

32. Roth J, Glick SM, Yalow RS, Berson SA 1963 Hypoglycemia: a potent stimulus to secretion of growth hormone. Science 140:987

83. Roth J, Glick SM, Yalow RS, Berson SA 1963 Secretion of human growth hormone: physiologic and experimental modification. Metabolism 12 (7):577

84. Russell SM, Hughes JP, Nicoll CS 1980 Differential effects of hypothalamic extract on release of bioactive and immunoactive rat growth hormone in vitro. Neuroendocrinology 30:355

85. Russell SM, Vodian MA, Hughes JP, Nicoll CS 1978 Electrophoretic separation of forms of rat growth hormone with different bioassay and radioimmunoassay activities: comparison of intraglandular and secreted forms. Life Sciences $23: 2373$

86. Satyanarayana T, Grindeland RE, Vasques $M$, Fast TN Comparison of growth hormone receptors of male rat livers and muscles. 70th Annual Meeting of the Endocrine Society, New Orleans LA, 1988 (Abstract no. 258)

87. Sawano A, Arimura A, Bowers CY, Redding TW, Schally AV 1968 Pituitary and plasma growth hormone-like activity after administration of highly purified pig growth hormone-releasing factor. Proc. Soc. Exp. Biol. Med. 127:1010

88. Schalch DS 1967 The influence of physical stress and exercise on growth hormone and insulin secretion in man. J. Lab. \& Clin. Med. 69:256

89. Schalch DS, Reichlin S 1966 Plasma growth hormone concentration in the rat determined by radioimmunoassay: influence of sex, pregnancy, lactation, anesthesia, hypophysectomy and exirasellar pituitary transplants. Endocrinology
$79: 275$

90. Schalch DS, Reichlin S 1968 Stress and growth hormone release. In: Pecile A and Muller EE (eds) Growth Hormone. Excerpta Medica, Amsterdam. pp 211-
225

91. Schally AV, Arimura A, Wakabayashi I, Redding TW, Dickerman E, Meites J 1972 Biological activity of a synthetic decapeptide corresponding to the proposed growth hormone-releasing hormone. Experientia 15(2):205

92. Schally AV, Baba Y, Nair RMG, Bennett CD 1971 The amino acid sequence of porcine growth hormone-releasing hormone. J. Biol. Chem. 246:6647 93. Schally AV, Coy DH, and Meyers CA 1978 Hypothalamic regulatory hormones.
Ann. Rev. Biochem. 47:89 
94. Schoenle E, Hauri E, Steiner T, Zapf J, Froesch ER 1985 Comparison of in vivo effects of insulin-like growth factors $I$ and II and of growth hormone in hypophysectomized rats. ACTA Endocrinologica 108:167

95. Seifert H, Perrin M, Rivier J, Vale W 1985 Binding sites for growth hormone releasing factor on rat anterior pituitary cells. Nature 313:487

96. Shortman K 1968 The separation of different cell classes from lymphoid organs. Aust. J. Exp. Biol. Med. Sci. 46:375

97. Sinha YN, Jacobsen BP 1987 . Glycosylated growth hormone: detection in murine pituitary gland and evidence of physiological fluctuations. Biochem. Biophys. Res. Comm. 145:1368

98. Snyder G, Hymer WC 1975 Secretion of growth hormone (GH) from cultures of purified somatotrophs. Federation Proceedings 34:272

99. Snyder G, Hymer W, Snyder J 1977 Functional heterogeneity in somatotrophs isolated from the rat anterior pituitary. Endocrinology 101:788

100. Speiss J, Rivier J, Vale W 1983 Characterization of rat hypothalamic growth hormone-releasing factor. Nature 303:532

101. Stachura ME 1976 Influence of synthetic somatostatin upon growth hormone release from perifused rat pituitaries. Endocrinology 99:678

102. Stachura ME, Frohman LA 1975 Growth hormone: Independent release of big and small forms from rat pituitary in vitro. Science $187: 447$

103. Stolar MW, Amburn K, Baumann G 1984 Plasma "big" and "big-big" growth hormone (GH) in man: an oligomeric series composed of structurally diverse GH monomers. J. Clin Endocrinol. Metab. 59:212

104. Takahashi K, Daughaday WH, Kipnis DM 1971 Regulation of immunoreactive growth hormone secretion in male rats. Endocrinology 88:909

105. Tannenbaum GS, Epelbaum J, Colle E, Brazeau P, Martin JB 1978 Antiserum to somatostatin reverses starvation-induced inhibition of growth hormone but not insulin secretion. Endocrinology 102:1909

106. Terry LC, Willoughby JO, Brazeau P, Martin JB, Patel Y 1976 Antiserum to somatostatin prevents stress-induced inhibition of growth hormone secretion in the rat. Science 192:565 107. Vale W, Rivier C, Brown M 1977 Regulatory peptides of the hypothalamus. Ann.
Rev. Physiol. 39:473

108. Vale W, Vaughan J, Yamomoto G, Rivier J 1983 Effects of synthetic human pancreatic (tumor) releasing factor and somatostatin, triiodothyronine and dexamethasone on $\mathrm{GH}$ secretion in vitro. Endocrinology 112(4):1553 
109. Vodian M, Nicoll C 1977 Growth hormone releasing factor and the bioassayradioimmunoassay paradox revisited. ACTA Endocrinologica $86: 71$

110. Vodian MA, Nicoll CS 1979 Evidence to suggest that rat growth hormone is modified when secreted by the pituitary gland. J. Endocr. 80:69

111. Wehrenberg WB, Baird A, Ying SY, Rivier C, Ling N, Guillemin R 1984 Multiple stimulation of the adenohypophysis by combinations of hypothalamic releasing factors. Endocrinology 114:1995

112. Wehrenberg WB, Ling N, Bohlen P, Esch F, Brazeau P, Guillemin R 1982 Physiological roles of somatocrinin and somatostatin in the regulation of growth hormone secretion. Biochem. and Biophys. Res. Comm. 109(2):562

113. Weiner N, Taylor $P 1985$ Neurohumoral transmission: the autonomic and somatic motor nervous systems. In: Gilman AG, Goodman LS, Rall TW, and Murad $F$ (eds) Goodman and Gilman's The Pharmacological Basis of Therapeutics, 7th ed. Macmillan Publishing Company, New York. pp 84-46

114. Wilfinger W, Davis J, Augustine E, Hymer WC 1979 The effects of culture conditions on prolactin and growth hormone production by rat anterior pituitary cells. Endocrinology 105:530

115. Wislocki GB, King CS 1936 The permeability of the hypophysis and hypothalamus to vital dyes, with the study of the hypophyseal vascular supply. Am. J. Anat. 58:421

116. Yasuda N, Greer MA, Aizawa T 1982 Corticotropin-releasing factor. Endocr. Rev. 3:123

117. Yokoya S, Friesen HG 1986 Human growth hormone (GH)-releasing factor stimulates and somatostatin inhibits the release of rat GH variants. Endocrinology
$119: 2097$ 